\title{
Application of Creative Thinking Method in Solving Urban Environment Waste Management as a Social Problem
}

\author{
Agnesa Saracini ${ }^{\star}$, Sofija Sidorenko
}

Faculty of Mechanical Engineering, Industrial Design, Ss "Cyril and Methodius" University of Skopje, Skopje, Republic of Macedonia

\begin{abstract}
Citation: Saracini A, Sidorenko S. Application of Creative Thinking Method in Solving Urban Environment Waste Dec 30; 10043:1-102. https://doi.org/10.3889/seejad.2019.10043

Keywords: Design with social impact: Creative thinking; Keywords: Design with social impact; Creative thinking Environmental protection; Web design

*Correspondence: Agnesa Saracini Faculty of Mechanical Engineering, Industrial Design. Fs "Cyril and Methodius" University of Skopje, Skopje, Republic of Macedonia. E-mail: agnesaracini@gmail.com

Received: 30-Oct-2019. Revised: 25-Nov-2019; Received: $30-O c t-2019 ; \quad$ Revised: $25-N o v-201$
Accepted: $27-N o v-2019$; Online first: $30-D e c-2019$

Copyright: ๑ 2019 Agnesa Saracini, Sofija Sidorenko. of the Creative Commons Attribution-NonCommercial 4.0 International License (CC BY-NC 4.0).

Funding: This research did not receive any financial support.

Competing Interests: The authors have declared that no ing interests exist.
\end{abstract}

\section{Abstract}

This master thesis contains a detailed research on a specific social problem-the poor waste management and consequently the extreme pollution of urban environment. By targeting a specific region, the municipality of Karposh with its citizens, and through the use of all 5 phases of "Design with social impact" methodology, we were able to come up with promising ideas and solutions for this problem.

The first phase set the baseline for a general review of the magnitude of the social problem and evaluated citizens' opinions regarding the issue. This stage aimed to achieve initial understanding of the problem, empathizing with the citizens in order to look at the problem from their aspect through in-depth exploration of different aspects using several creative techniques. In the second phase, the analysis continues with a comprehensive research, the results of which were presented in the form of statistics on waste in the world and in our country, finding successful examples from other countries on the management of these issues. All the aforementioned information identified the main causes for the worrying status-quo and defined the exact goal of the thesis. Furthermore, the third phase generated several concept ideas as possible solutions to the given problem. The final concept, chosen for realization, was the idea of a web portal aimed at educating and informing the citizens in order to raise awareness of the necessity of a more serious approach towards waste management issues in urban areas. As a result, a web portal prototype was developed in the fourth phase in accordance with the set goals and requirements based on the information gathered in the previous stages. The portal was available online and it was reviewed by many concerned citizens who provided comments and suggestions for its improvement. Currently, the fifth phase is in the process of realization.

This master thesis is designed and implemented as an example that demonstrates the power of creative thinking inherently linked with creative professions, such as designers, and the power of socially influenced design methodology to solve specific social problems. Given the fact that every society has many problems, designers with their abilities can and should play a big role in their solving. 


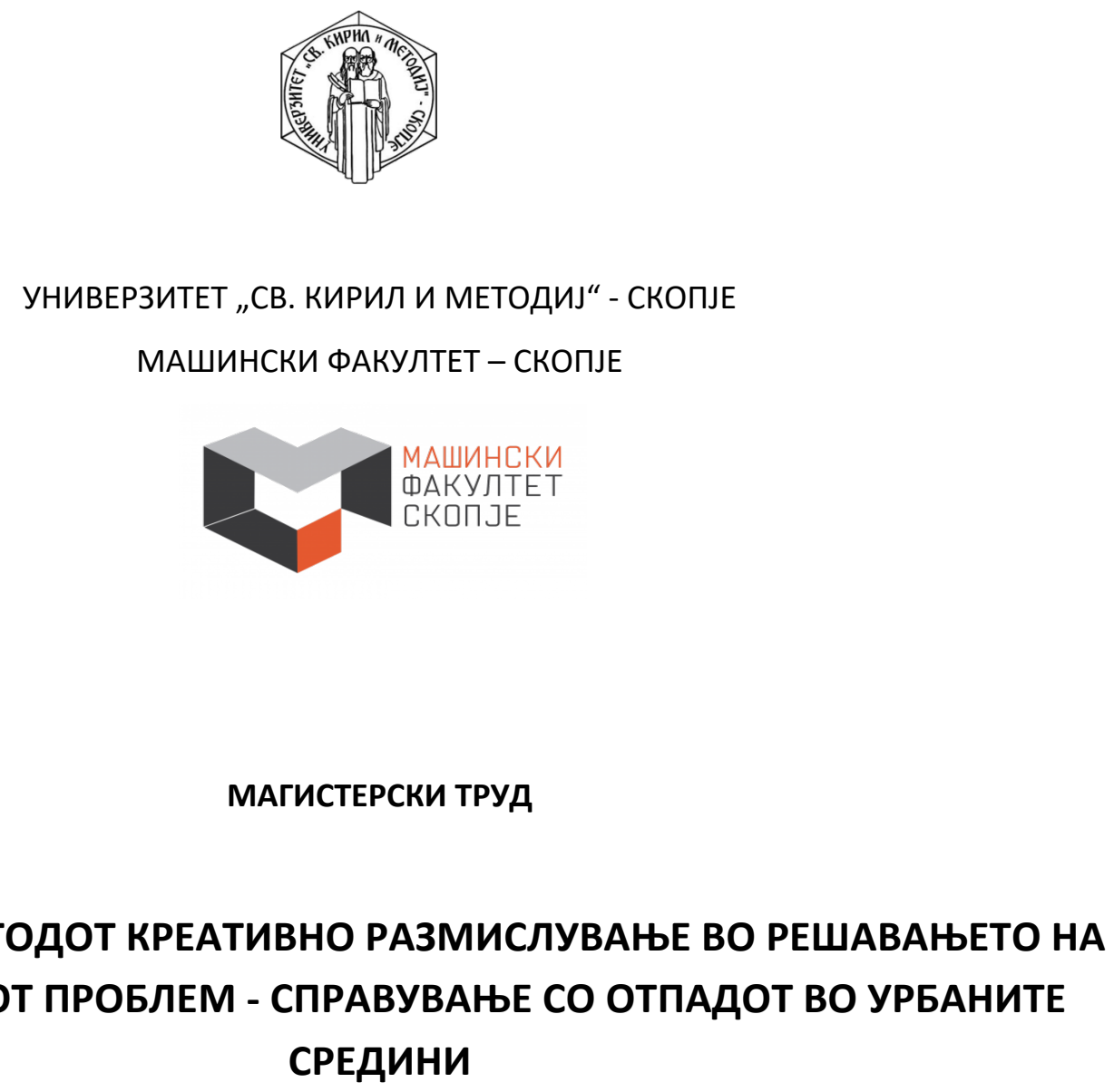

\title{
ПРИМЕНА НА МЕТОДОТ КРЕАТИВНО РАЗМИСЛУВАЊЕ ВО РЕШАВАЊЕТО НА ОПШТЕСТВЕНИОТ ПРОБЛЕМ - СПРАВУВАЊЕ СО ОТПАДОТ ВО УРБАНИТЕ СРЕДИНИ
}

\author{
Кандидат: Агнеса Сарачини \\ Ментор: Проф. д-р Софија Сидоренко
}

Постдипломски студии по индустриски дизајн и маркетинг

Скопје, октомври 2019 
Ментор:

Членови на комисијата:

Дата на одбрана:

Дата на промоција:
Проф. д-р Софија Сидоренко

Машински факултет - Скопје

Проф. д-р Софија Сидоренко

Машински факултет - Скопје

Проф. д-р Татјана Кандикјан

Машински факултет - Скопје

Доц. д-р Ташко Ризов

Машински факултет - Скопје 
Агнеса Сарачини, дипломиран инженер по индустриски дизајн

\section{Примена на методот креативно размислување во решавањето на општествениот проблем - справување со отпадот во урбаните средини}

Апстракт:

Во овој магистерски труд е извршено истражување поврзано со конкретен општествен проблем - големи количини различни видови отпад расфрлани во урбаните средини. Со цел да се дојде до конкретен предлог за решавање на зададениот проблем применет е целокупниот креативен процес во пет фази според методологијата дизајн со општествено влијание. Беше избран конкретен реон во градот, поточно Општината Карпош, а таргет група беа жителите на оваа општина.

Во првата фаза беше извршено реално согледување на целокупниот општествен проблем, неговите размери, какви се ставовите на граѓаните во врска со него. Во оваа фаза беше постигната емпатија, соживување со граѓаните со цел проблемот да се погледне од нивниот аспект преку деталното истражување од различни аспекти со примена на неколку креативни техники. Во втората фаза беа извршени темелни истражувања чии резултати беа презентирани во вид на статистички податоци за отпадот во светот и во нашата земја, изнаоѓање на успешни примери од други држави за тоа како тие се справуваат со овие прашања. Врз основа на сите истражувања, беа препознаени главните причини за состојбите и беше извршено попрецизно дефинирање на задачата. Во третата фаза беа генерирани голем број концепт идеи како можни решенија на зададениот проблем. Конечниот концепт избран за доработка и финализирање беше концептот на веб портал чија цел е едукација и информирање на граѓаните како да се подигне нивната свест за неопходноста од посериозен однос кон проблемите со справување со отпадот во урбаните средини. Во четвртата фаза беше изработен прототип на веб порталот според поставените цели и барања врз основа на собраните информации во претходните фази. Порталот беше ставен во интернет сообраќајот и прегледан од поголем број засегнати граѓани кои дадоа свои коментари и сугестии за подобрување на истиот. Петтата фаза е во процес на реализација.

Овој магистерски труд е оформен и реализиран како пример кој ја покажува моќта на креативното размислување, својствено за креативци како дизајнерите, како и моќта на методологијата дизајн со општествено влијание за решавање на конкретни општествени проблеми. Со оглед на фактот дека секое општество има голем број проблеми за решавање, дизајнерите со своите способности можат и треба да имаат голема улога во решавање на истите.

Клучни зборови: дизајн со општествено влијание, креативно размислување, менаџирање со отпад, процес на дизајнирање, загадување, заштита на животната средина, веб дизајн. 


\title{
Application of creative thinking method in solving urban environment waste management as a social problem
}

\begin{abstract}
:
This master thesis contains a detailed research on a specific social problem - the poor waste management and consequently the extreme pollution of urban environment. By targeting a specific region, the municipality of Karposh with its citizens, and through the use of all 5 phases of 'Design with social impact' methodology, we were able to come up with promising ideas and solutions for this problem.

The first phase set the baseline for a general review of the magnitude of the social problem and evaluated citizens' opinions regarding the issue. This stage aimed to achieve initial understanding of the problem, empathizing with the citizens in order to look at the problem from their aspect through indepth exploration of different aspects using several creative techniques. In the second phase, the analysis continues with a comprehensive research, the results of which were presented in the form of statistics on waste in the world and in our country, finding successful examples from other countries on the management of these issues. All the aforementioned information identified the main causes for the worrying status-quo and defined the exact goal of the thesis. Furthermore, the third phase generated a number of concept ideas as possible solutions to the given problem. The final concept, chosen for realization, was the idea of a web portal aimed at educating and informing the citizens in order to raise awareness of the necessity of a more serious approach towards waste management issues in urban areas. As a result, a web portal prototype was developed in the fourth phase in accordance with the set goals and requirements based on the information gathered in the previous stages. The portal was available online and it was reviewed by a large number of concerned citizens who provided comments and suggestions for its improvement. Currently, the fifth phase is in the process of realization.

This master thesis is designed and implemented as an example that demonstrates the power of creative thinking, inherently linked with creative professions, such as designers, and the power of socially influenced design methodology to solve specific social problems. Given the fact that every society has many problems, designers with their abilities can and should play a big role in their solving .
\end{abstract}

Key words: Design with social impact; Creative thinking; Waste management; Design processes; Pollution; Environmental protection; Web design. 
Оваа магистерска теза ја посветувам на моите родители Афердита и Нафи Сарачини за нивната безусловна постојана поддршка во текот на целиот процес, мојот брат инженер Леарт Сарачини и Шиви.

Посебна благодарност до мојот ментор и професор д-р. Софија Сидоренко, како и останатите професори од смерот Индустриски Дизајн затоа што несебично го насочуваа мојот академски развој во текот на последната декада и беа постојан потик за дополнително надоградување и усовршување.

Исто така голема благодарност и до моите блиски пријатели за цела нивна поддршка , трпение и помош во текот на целата година. 


\section{Содржина}

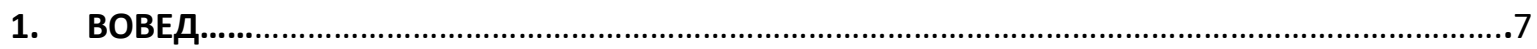

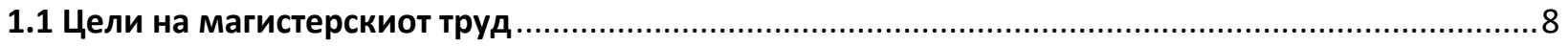

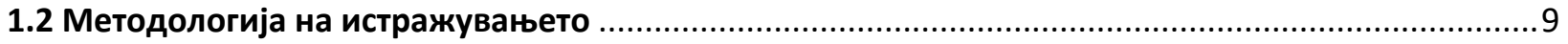

2. МЕТОДОЛОГИЈА ДИЗАЈН СО ОПШТЕСТВЕНО ВЛИЈАНИЕ .................................................... 11

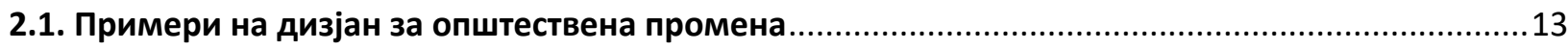

2.2.Актуелни проблеми во современото општество .................................................................17

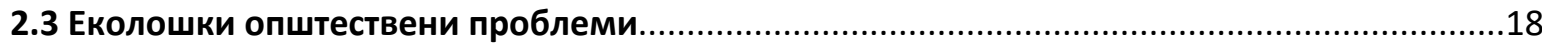

2.4. Решавање проблеми поврзани со животната средина.........................................................20

3. КРЕАТИВНОТО РАЗМИСЛУВАҢЕ КАКО ОСНОВА НА ДИЗАЈНОТ И ДИЗАЈНЕРСКИОТ НАЧИН НА

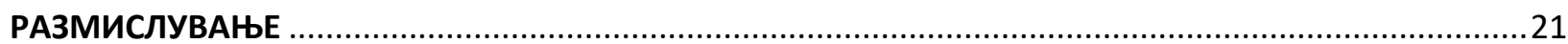

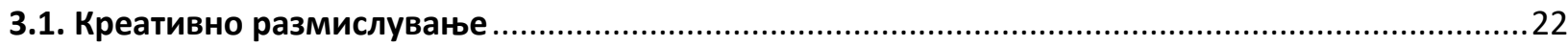

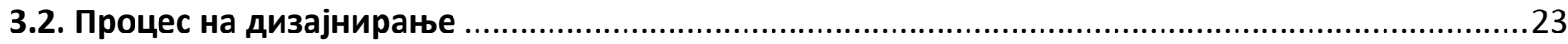

3.3. Процес на дизајнирање во решавањето проблеми од општествено значење.....................27

4. ПРИМЕНА НА КРЕАТИВНИТЕ ТЕХНИКИ ВО РЕШАВАЊЕ НА ОПШТЕСТВЕНИОТ ПРОБЛЕМ -

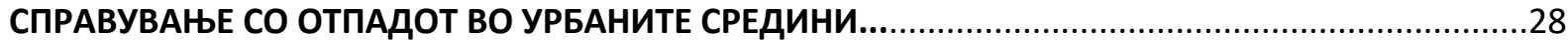

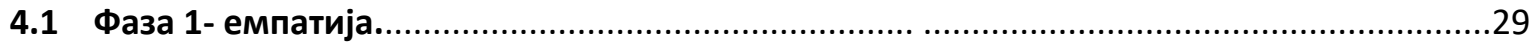

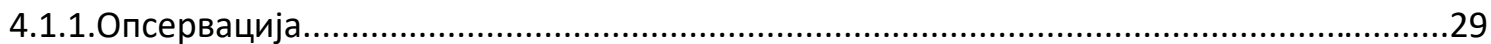

4.1.2 Креирање "mind-map" за проблемот како е разбран........................................................36

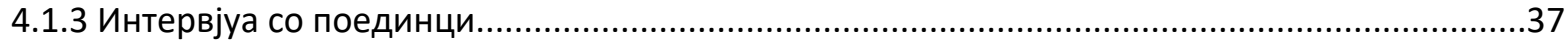

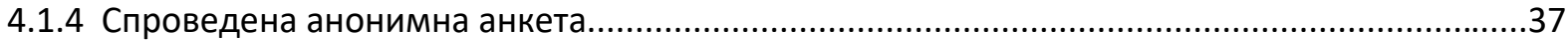

4.1.5 Реализирана работилница со избрана фокусна група.........................................................48

4.1.6 . SWOT анализа на состојбата со отпадот во градот Скопје.....................................................49

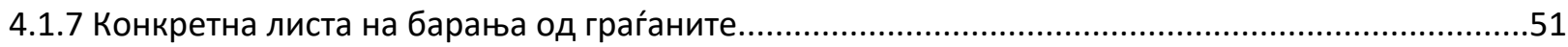

4.2 Фаза 2-дефинирање........................................................................................................52

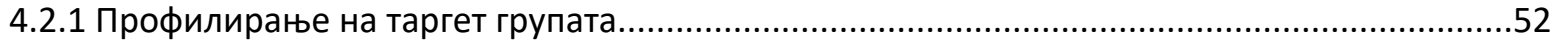

4.2.2. 'Briefing"- опис на задачата и воспоставување критериуми.......................................................52

4.2.3 Факти во врска со количините на отпад во светски рамки..............................................53

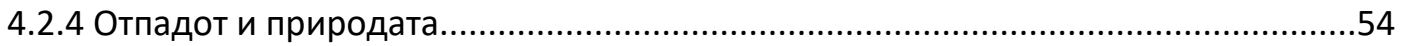

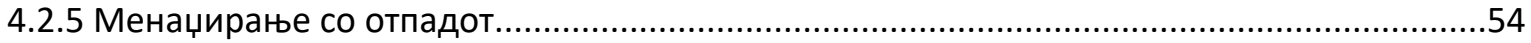

4.2.6 Намалување на загадувањето на животната околина преку рециклирање на отпадот......55 
4.2.7. Менаџирање и рециклирање на отпадот како бизнис ….......................................................55

4.2.8. Примери како се врши справување со отпадот во светот......................................................56

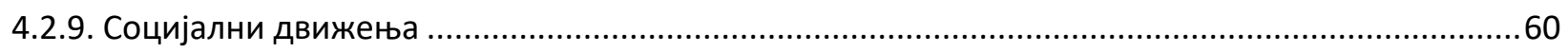

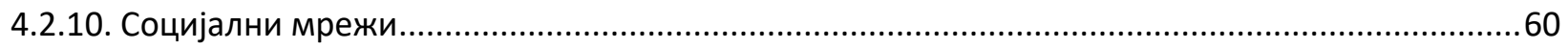

4.2.11 Состојбата со отпадот во Македонија.......................................................................63

4.2.12. Законски регулативи во врска со отпадот во Македонија ...................................................63

4.2.13. Статистики според Министерството за животна средина и просторно планирање...........66

4.2.14. Стратегии за справување со отпадот во Македонија

4.2.15. Иницијативи за реупотреба.

4.2.16. Неформални собирачи .69

4.2.17. Диви депонии .70

4.2.18. Независни иницијативи и организации .68

4.2.19. Истражување на мислењето на медиумите, каде тие го лоцираат проблемот со отпадот во Скопје.

4.3. Фаза 3 - генерирање идеи.

4.3.1 Бреинсторминг...... .73

4.3.2 Првични предлог концепти

4.3.3 Оценка на предложените концепти и избор на најдобар за понатамошна разработка.......79 4.3.4 Заклучок од извршениот избор на предлог концепти за решавање на зададениот проблем.78

4.4 Фаза 4-прототипирање.

4.4.1. Таргет група .81

4.4.2. Основни барања на дизјанот на веб-платформата. .79

4.4.3. Организација на податоците .80

4.4.4. Структура на веб-платформата. .82

4.4.5. Детална презентација на разработениот концепт

4.4.6 Дизајн на поединечните страни .85

4.4.7. Понатамошен развој .90

4.5. Фаза 5 - финализација и тестирање. .92

5. Заклучок. .97

Користена литература .97 


\section{1. ВОВЕД}

Сведоци сме на голем број проблеми кои имаат негативно влијание врз квалитетот на животот на граѓаните и околината во Република Македонија. Како најсериозен и најактуелен може да се земе проблемот со огромните количини на неконтролиран и несортиран отпад од разни категории. Отпадот е огромна загуба на ресурси во вид на енергија и материјали. Се вели дека преку количеството на отпад може да се мери ефикасноста на едно општество.

Секоја држава има свој начин на справување со отпадот, некаде тоа е решено така што не претставува никаква потешкотија во секојдневието и општеството, додека во други мотивацијата или иницијативите за справување со овој предизвик се речиси непостоечки. Македонија влегува во категоријата држави каде свеста на самите индивидуалци, поголеми групи и институциите за последиците од неодговорно однесување со отпадот е на многу ниско ниво. Токму затоа, решавањето на овој социјален проблем е главниот предизвик во овој магистерски труд.

Отпадот постоел отсекогаш, но не претставувал проблем како во денешно време. Во минатото луѓето консумирале работи директно од природата што резултира со креирање на органски отпад, кој на крај природно се разградува. Отпад се создавал секогаш од сите живи суштества, но тој бил во хармонија со еко-системот и природно се трансформирал во корисен органски ресурс за други битија.

Индустријализацијата предизвика криза која денес е оквалификувана како „отпадочна криза“. Развојот на технологиите оневозможува отпадот да се разгради во нутритивни вредности за организми. Со индустриската револуција отпадот веќе стана нешто што природата не може да го „прочита“ и да се справи со него како претходно. На новите материјали им се потребни стотици или илјадници години за да се распаднат, ако воопшто ја поседуваат таа карактеристика [13].

Друг фактор кој придонесува за оваа криза е масовната потрошувачка. Развојот на економијата и технологиите овозможува масовно и брзо производство и консумација на исто ниво. Ова доведува до фактот дека поразвиените и економски стабилни држави придонесуваат многу повеќе за оваа криза за разлика од понеразвиените општества.

Со проблеми од еколошки тип се справува секое општество - и поразвиените и помалку развиените. Доколку не бидат решени навреме тие создаваат синџир на проблеми кои доведуваат до долгорочни екстремно штетни последици за живите суштества и екосистемот. Еколошки проблеми се создаваат поради лошо планирање, дизајнирање без да се размисли за крајот на животниот век на производот, поради брз материјален профит, честопати поради некористење на вистинските инструменти итн. 


\section{1 Цели на магистерскиот труд}

Главна цел на овој магистерски труд е да се даде предлог како да се подобрат условите за живеење на граѓаните на Скопје преку решавање на конкретен општествен проблем со примена на методологијата дизајн со општествено влијание. Во фазата на трагање по вистинскиот предизвик вниманието ми го привлекоа големи количини на различни видови отпад на улиците во градот Скопје. Како учесник во меѓународниот проект „Дизајн со општествено влијание“, реализиран во периодот 2015-2017 година како соработка помеѓу Универзитетот за применети уметности од Цирих и Машинскиот факултет во Скопје, ја осознав моќта на дизајнерите и креативните методи и техники кои тие ги користат во процесот на дизајнирање како силна алатка за препознавање на општествени проблеми и способност да дадат придонес во нивното решавање.

Главното прашање кое беше поставено на почетокот од ова истражување беше „која е вистинската причина за сегашната состојба?“. Имајќи предвид дека постојат институции и компании чија главна дејност е грижата за чистотата на околината, собирање на отпадот, третирање и негово рециклирање, природно се наметнува дилемата колку ефикасно си ја вршат својата работа. За да се испита тој домен, првенствено е неопходно да се одговори на следното главно истражувачко прашање:

Колку систематизирано и успешно се управува со отпадот во Република Македонија од страна на институциите и компаниите и колку тоа придонесува за намалено загадување во урбаните средини?

Институциите се најповикани да одговорат на ова прашање бидејќи имаат моќ да носат законски регулативи кои мораат да бидат почитувани од сите. Компаниите, од друга страна, се најспособни да се грижат и да го регулираат проблемот со отпадот поради тоа што се водени од профит. Оттука, битно е да знаеме дали воопшто е профитабилно занимавањето со овој бизнис во нашата држава и дали се генерира доволно материјал кој ги задоволува очекувањата на компаниите.

Институциите и компаниите се со ограничена можност да инвестираат во нови креативни решенија кои би решиле дел од проблемите со кои се соочуваме во моментов. Поради тоа, вниманието треба да се насочи и кон тие кои го создаваат отпадот. Собраниот отпад од домаќинствата во урбаните средини претставува најголем дел од целиот генериран отпад во градовите. Тоа го наметнува прашањето дали навиките или свеста на индивидуалците кои дневно создаваат повеќе од килограм отпад се всушност вистинскиот проблем? Оттука произлегува и првото споредно истражувачкото прашање:

До кој степен граѓаните на Република Македонија се информирани и мотивирани правилно да го одлагаат отпадот во урбаните средини?

Кој е вистинскиот начин да се информираат граѓаните? Дали во моментот има доволно лесно достапни информации? Како да се подигне свеста кај индивидуалците за последиците од непрописно однесување со отпадот? Ова се само дел од прашањата кои помагаат во лоцирањето на проблемот за истражување на поставеното истражувачко прашање. Покрај лоцирањето на 
причинителите на загадувањето, многу важен дел од проблематиката е наоѓањето на вистинско решение кое би можело да ги задоволи очекувањата на сите без некој или нешто да биде изоставено. Оттука, второто споредно истражувачкото прашање гласи:

На кој начин креативните решенија би помогнале во решавањето на проблемот со omпадоm?

Дали дизајнерските методи и размислувања можат да доведат до вистинско решение кое е применливо и ќе направи позитивна промена во општеството од која сите би биле задоволни? Дизајн размислувањето може да генерира разни идејни решенија кои би имале општествено влијание во нашата држава во врска со загадувањето поради неконтролиран отпад. Поточно, таквото размислување може да понуди вистински, современи и ефикасни начини за справување со отпад од разни категории во урбаните средини.

\section{2 Методологија на истражувањето}

Во овој труд е извршено истражување поврзано со конкретен општествен проблем големи количини различни видови отпад расфрлани во урбаните средини. Со цел да се дојде до конкретен предлог за решавање на зададениот проблем применет е целокупниот креативен процес во пет фази, според методологијата дизајн со општествено влијание. Истражувани и користени се современите сознанија од областа на дизајнот со општествено влијание, што има големо значење во квалитетното решавање на проблемите. Беше избран конкретен реон во градот, поточно Општината Карпош, а таргет група беа жителите на овој регион.

Во првата фаза беше извршено реално согледување на целокупниот општествен проблем, неговите размери, какви се ставовите на граѓаните во врска со него. Во оваа фаза беше постигната емпатија, соживување со граѓаните со цел проблемот да се погледне од нивниот аспект. За таа цел беа применети техниките на интервјуирање, анкетирање, работилница, swot анализа итн. Деталното истражување од различни аспекти, овозможи јасно согледување на проблемот и неговите размери.

Во втората фаза беа извршени темелни истражувања чии резултати беа презентирани во вид на статистички податоци за отпадот во светот и во нашата земја, изнаоѓање на успешни примери од други држави за тоа како тие се справуваат со овие прашања. Врз основа на сите истражувања, беа препознаени главните причини за состојбите и беше извршено попрецизно дефинирање на задачата.

Во третата фаза беа генерирани голем број концепти идеи како можни решенија на зададениот проблем. Конечниот концепт избран за доработка и финализирање беше концептот на веб портал чија цел е едукација и информирање на граѓаните како да се подигне нивната свест за неопходноста од посериозен однос кон проблемите со справување со отпадот во урбаните средини.

Во четвртата фаза беше изработен прототип на веб порталот според поставените цели и барања врз основа на собраните информации во претходните фази. Порталот беше ставен во 
интернет сообраќајот и прегледан од поголем број засегнати граѓани кои дадоа свои коментари и сугестии за подобрување на истиот.

Петтата фаза е последната фаза од секој креативен процес, поточно финализација и пуштање во употреба на креираното дело, во овој случај веб портал наменет за подигнување на свеста на граѓаните во врска со справувањето со отпадот во урбаните средини. Во првата недела од неговото пуштање во употреба, веб- порталот беше одлично прифатен ,доби многу голема поддршка на социјалните мрежи, како и голема посетеност. Но за да се добие вистинска слика за успешноста на идејата после имплементирање сепак треба да помине одреден временски период.

Овој магистерски труд е оформен и реализиран како пример кој ја покажува моќта на креативното размислување, својствено за креативци како дизајнерите, како и моќта на методологијата дизајн со општествено влијание за решавање на конкретни општествени проблеми. Со оглед на фактот дека секое општество има голем број проблеми за решавање, дизајнерите со своите способности можат и треба да имаат голема улога во решавање на истите. 


\section{2. МЕТОДОЛОГИЈА ДИЗАЈН СО ОПШТЕСТВЕНО ВЛИЈАНИЕ}

"Дизајн со општествено влијание не е лесно да се оствари. Тоа е многу комплексен процес, кој носи голема одговорност за дизајнерите. Дизајнерите се истражувачите, во потрага по скриеното богатство." - Кристофер Џоунс [23].

Дизајн за општествено влијание е долг процес на истражување институционални, економски, социјални, политички, интерперсонални системи, со цел да се дефинираат можности за промена. Тоа е процес кој, исто така, дава глас на тие кои се непривилегирани во многу контексти. Во суштина овој феномен има за цел да направи позитивни промени во општеството или за одредени групи.

„Поради тоа ито дизајн размислувањето ги балансира перспективата на корисникот, технологијата и бизнисот, по природа само по себе е интегративен феномен."- вели Тим Браун во неговата книга „Промена преку дизајн“ [7].

Дизајнерите ги опсервираат луѓето како се однесуваат, како контекстот на нивното искуство влијае на нивните реакции кон производите и услугите. Тие ги земаат во предвид емоционалното значење на работите, како и нивните функционални перформанси. Од тука се обидуваат да ги идентификуваат не покажаните или скриените потреби на луѓето и истите да ги претворат во можности. Ваквиот пристап на дизајнерите каде човекот е центарот, може да информира, да даде нови понуди и да ги зголеми шансите за нивно прифаќање поврзувајќи ги со веќе постоечко однесување.

Поставување на вистинските прашања често го детерминира успехот на новиот производ или услуга:

- Дали ги задоволува потребите на таргетираната популација?

- Дали креира значење и вредност?

- Дали инспирира ново однесување?

- Дали претставува пресвртна точка?

Во оваа општествена област успехот не се мери со произведување предмет или завршување на проектот, напротив, се мери со внимателна опсервација, повратни информации ("feed back") и долгорочна проценка. Повратните информации имаат критично значење за дизајн со општествено влијание, бидејќи од нив зависи успешноста, што значи не се базира на тоа што дизајнерот мисли дека го постигнал, туку на одговорот на корисниците и нивното искуство.

Дизајнот за општественото влијание може да се мери со:

- $\quad$ Непосредните добивки - дали системот функционира така како што било планирано.

- $\quad$ Промените кои се случуваат при вклучување на луѓето во системот во даденото место и време.

- На крај, најважен е долгорочниот успех, а не реакцијата во самиот момент на имплементирање. 
- $\quad$ Задоволително решение е тоа кога промените се видливи со тек на време и системот и идеите се прифатени и практикувани.

Во текот на процесот на дизајнирање за социјална промена треба да се запазат неколку аспекти:

- Многу е важно да постои соработка, афектираната групата активно да биде инволвирана во текот на процесот, давајќи фидбек и увид. Таргетираните групи се експерти за проблемот со кој се справуваат, клучно е тие да бидат послушани и да се има емпатија кон нив. Само тогаш решението има шанса за долгорочен успех.

- Без разлика колку се брилијантни идеите на дизајнерите, единственото нешто што е важно е тоа дали ги исполнува потребите на таргет групата. Исто така, треба да се верифицира дека идеите би ја подобриле ситуацијата.

- $\quad$ При процесот на дизајнирање треба да се елиминираат сите штетни стереотипи и дисбаланси на моќ со цел да се избегнат концепти кои директно или индиректно би наштетиле / навредиле / повредиле корисник.

- П Преку ригорозно тестирање треба да се осигура дека процесот оди во вистинска насока. Најдобро е да се тестира пред целосната имплементација на идејата, на овој начин се избегнува неуспех и проблемите може да бидат откриени и поправени на време.

- $\quad$ Секогаш треба да се стреми кон долгорочни решенија кои се трајни.

- $\quad$ Наоѓaње инспирација, студирање на успешно завршени проекти, себе-едуцирање и критично размислување се екстремно важни елементи во овој процес.

Гретчен Андерсон во својата книга „Дизајнирање на општествено влијание“[3] тврди дека дизајнерите се' повеќе сакаат да бидат вклучени во ваков тип проекти, со цел да остават некаков белег за глобалното добро, бидејќи тие можат најефективно да го искористат своето знаење и алатки за создавање позитивни социјални промени

Таа исто така ги потврдува воспоставените чекори и дека во овој процес е важно да се дизајнира со луѓето наместо за нив, преку емпатија и учејќи што најдобро функционира од методите кои треба да помогнат во создавање долгорочни промени во однесувањето, системот или услугата. Исто така, потенцира дека одлуките кои се донесуваат треба да имаат влијание врз сите кои се афектирани, а не само врз одредена група која е можеби најлесно достапна. Ваков вид на работа носи многу голема одговорност и е нетолерантна за несигурни или ризични солуции.

Интересот за социјални иновации расте и има голема поддршка и од власта која помага при креирање социјални иновативни стратегии, користејќи го целиот потенцијал на дизајнерите. Социјалните иновации ги поместуваат традиционалните граници помеѓу пазарот, власта и граѓанското општество, развивајќи нови форми на услуги, врски, колаборации. Социјалните иновации имаат големо влијание и моќ да трансформираат едно општество и да го подобрат [26].

Дизајнот и социјалните иновации се тесно поврзани. Дизајнерите треба да се сметаат за експерти кои работат кон постигнување заеднички цели, во смисла дека потенцијално сите можат да учествуваат во животните проекти. Колаборативни проекти доведуваат до уникатни резултати, 
но треба да се запамети дека има голема разлика помеѓу дизајн кој секој може да го направи и експертен дизајн кој се креира само од добро тренирани дизајнери. Добрата соработка е клучна за остварување на целта [27].

„Опитествено влијание значи дека една активност го менува животот на луд́ето кон подобро. Со други зборови, демонстрира врска причинител-и-ефект помеѓу активностите и резултатот од кој луѓето имаат корист". Ед Гарнер[24]

\section{1. Примери на дизајн за општествена промена}

Скоро 90\% од светската популација немаат или имаат многу лимитиран пристап до производи или услуги кои на останатите им се секојдневие. Повеќе од половината од нив немаат регуларен пристап до храна, чиста вода или засолништа. Движењето дизајн со општествено влијание овозможува дизајнерите, инженерите, архитектите, студентите, разни прогресивни личности, да им помогнат на тие 90\% маргинализирани и сиромашни во креирањето евтини решенија со кои ќе се подобри нивниот животот. Постојат многу примери за добро дизајнирани успешни проекти, но секако постојат и примери за пропаднати идеи од кои треба да се извлече поука.

Ikea

Во минатите години бевме сведоци на масовна емиграција на бегалци во Азија и Европа. Оваа појава ја инспирираше шведската компанија Икеа за „Светскиот Ден на Бегалци“ да произведе ново засолниште кое може лесно и брзо да се спакува, со модуларен дизајн и соларни панели, дизајниран да ги подобри условите на живеење за бегалците (сл. 1). Овие засолништа може да се изградат екстремно брзо, обезбедувајќи дом во итни случаи за жртви на природни катастрофи, бегалци и сл.

\section{Firefly Centre}

Минатогодишниот добитник на наградата за Дизајн со општествено влијание „Сore77 Design Awards 2018" се нарекува Firefly Centre и е управувачки центар во проблематични населби. Со цел да го подобрат квалитет на живот во поскромните области, резидентите почнале да го дизајнираат и креираат Фајрфлај Центарот. Овој Центар нуди дневна грижа, разни услуги, разни алатки и простории, слично на услугите кои би ги добиле во комплекс од апартмани (сл.2.). Исто така, доколку биде побарано од страна на жените да бидат придружувани тие ќе бидат испратени до нивните домови во доцните ноќни часови. Резидентите сами го менаџираат овој центар под контрола на системски регулативи. Првичниот резултат е многу позитивен, но останува на времето да покаже колку ќе биде ефективен [40]. 


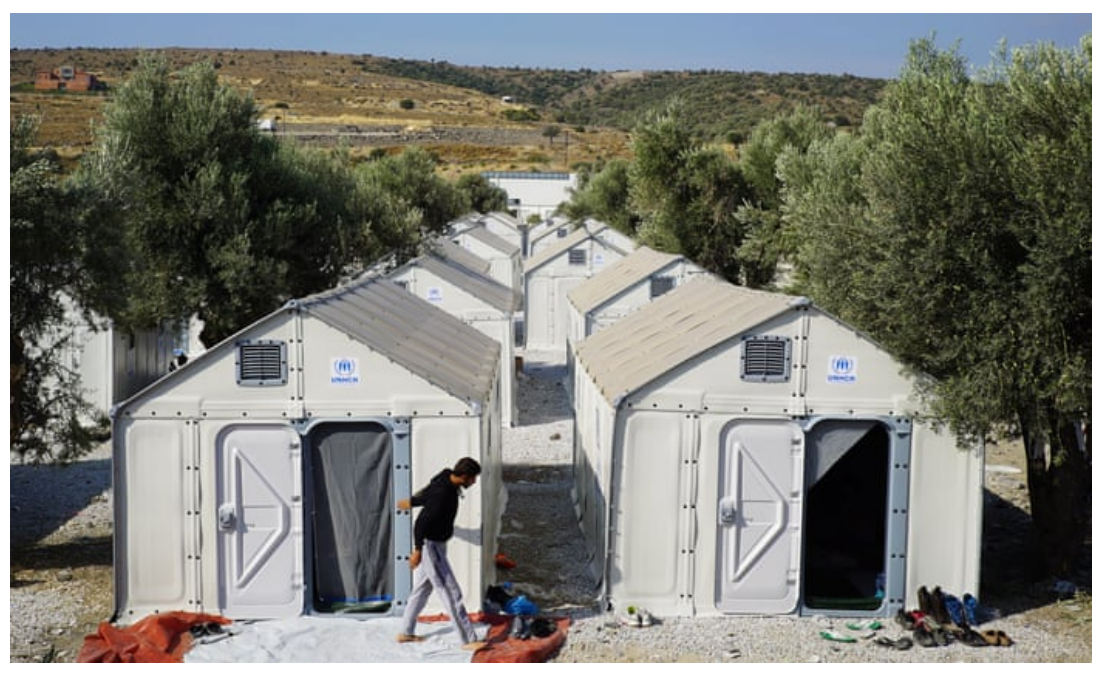

Сл. 1. Засолништа за бегалци на Икеа
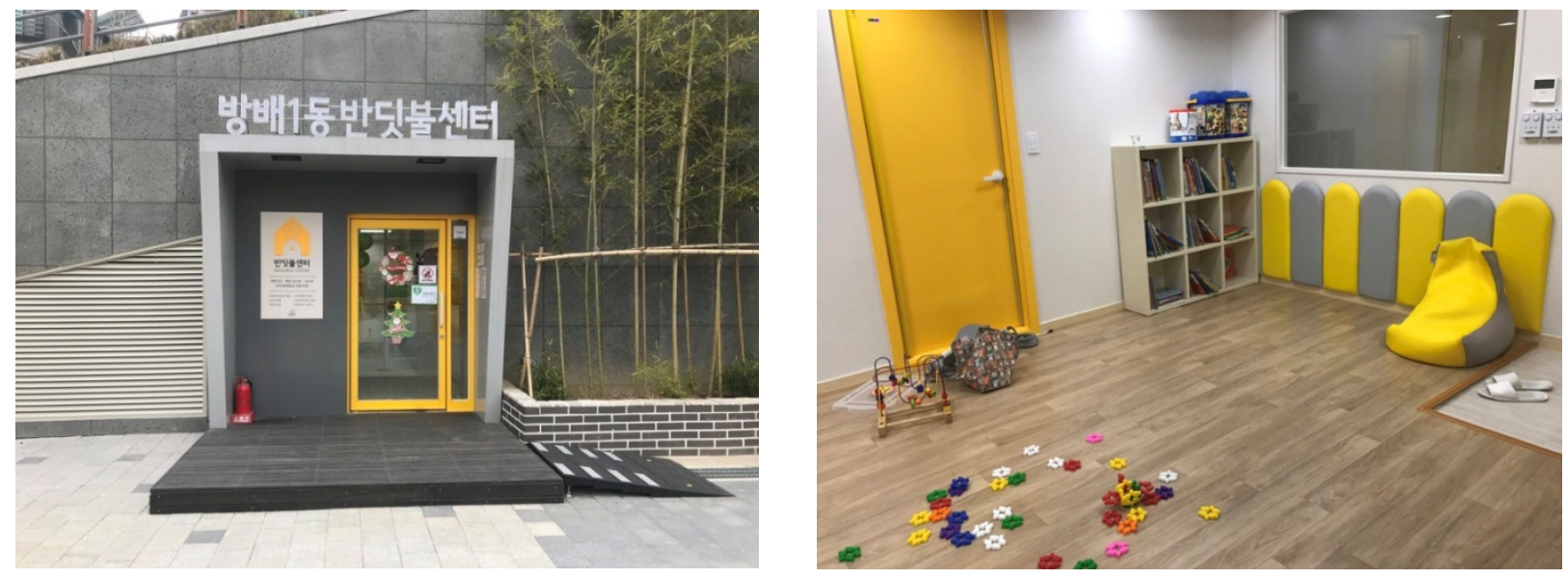

Сл. 2. "Firefly" центар

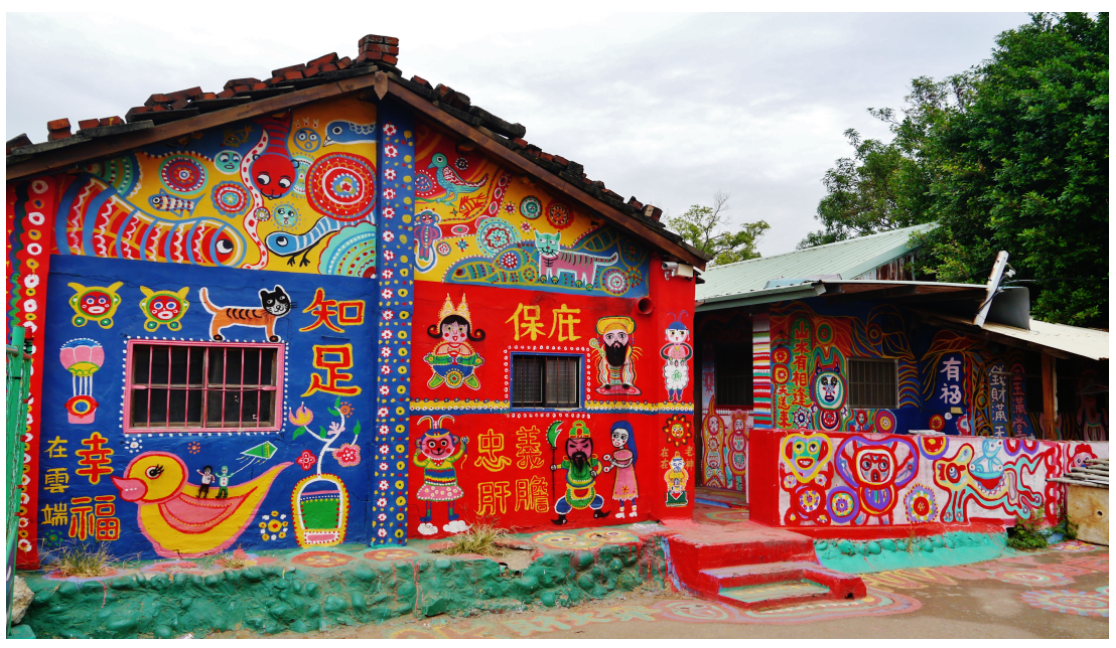

Сл. 3. Фасади во „Виножитно“ село 


\section{Rainbow Village}

Друг интересен пример е „Виножитното село“ во Тајван. Пред околу десетина години истото тоа село добило закана од власта дека ќе биде срушено. Еден постар жител, сега познат како дедо Виножито, поради силната емотивна поврзаност не сакал да го напушти својот дом, па почнал да ги слика со разни бои зидовите, подовите, улиците, фасадите на сите објекти во селото, што резултирало со голема посетеност од странци(сл.3.). Денес тоа мало место е голема туристичка атракција, додека Huang Yung-fu или дедо Виножито се смета за херој кој го спасил селото [38].

\section{TYIN Tegnestue}

За Андреас Гјерстен и Јашар Јамдстад живеењето една година на брод било инспирација да започнат со креирање „архитектура на неопходност“ поради што се преселиле во Тајланд каде една година поминале дизајнирајќи и градејќи библиотека, игралишта, бањи за деца од Сејф Хевн домот(сл.4). Користејќи ги веќе постоечките структури, како и локалните ресурси, успеале да го направат тоа со минимални штети за околината и со многу мал трошок. Покрај тоа што помогнале на децата тие ги промовирале и потенцијалите на локалните ресурси како предизвик за слични проекти [41].

\section{FabScrap}

Текстилната индустрија се справува со голем проблем во врска со загадувањето на водите и текстилниот отпад кој го создава. 15 \% од материјалите завршуваат на подовите од фабриките, а често само за еден „high end“ производ, 10 \% од потребниот материјал се користи, додека останатите 90\% завршуваат во контејнер. ФабСкарп е компанија за рециклирање и реупотреба на текстил која секојдневно со свој транспорт ги собираат сите текстилни остатоци од разни компании, брендови, фабрики, дизајнери(сл.6). Остатоците ги рециклираат или реупотребуваат креирајќи гардероба. Исто така, отворени се за соработка со модни дизајнери кои ја поддржуваат оваа инцијатива. Еден од нив е и Zero Waste Daniel(сл.5), сега веќе многу познат, кој шие креации од собраните текстилни остатоци [42].

\section{Fare share}

Секојдневно маркетите отстрануваат храна која е сеуште добра за консумација. Фер Шер е една од иницијативите која се бори за редуцирање на храна која завршува во отпад. Тие собираат храна која маркетите веќе не можат да ја продаваат, но е со добар квалитет и консумабилна. Потоа истата ја дистрибуираат и донираат за добротворни цели, хранејќи илјадници луѓе кои имаат потреба.

\section{Водоводна инсталација во Африка}

За жал постојат и многу неуспешни проекти од кои може да се научи нешто. Еден од нив е водната инсталација во бунар во Африка(сл.7-8). Решението било многу добро прифатено во моментот на имплементирање, но големо разочарување со тек на време. Поради некоректно и нерегуларно неодржување, , бунарите се веќе комплетно нефункционални, принудувајќи ги 
жителите на Африка да се вратат на нивните стари начини на справување со проблемот со водата [28].

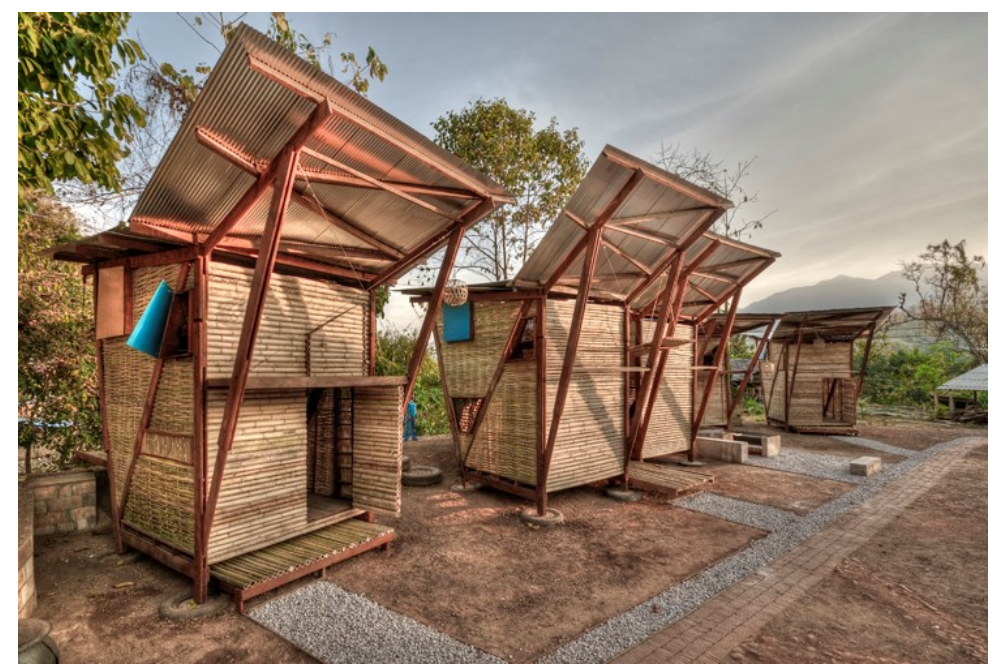

Сл. 4. Објекти во "Safe Heaven"

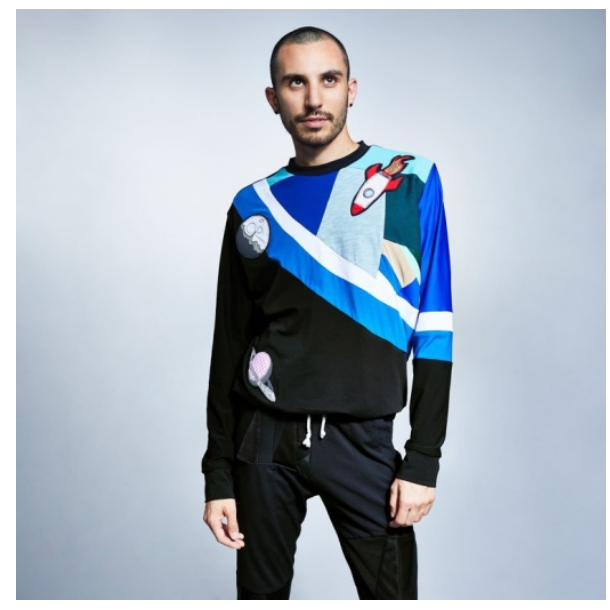

Сл. 5. Zero Waste Daniel

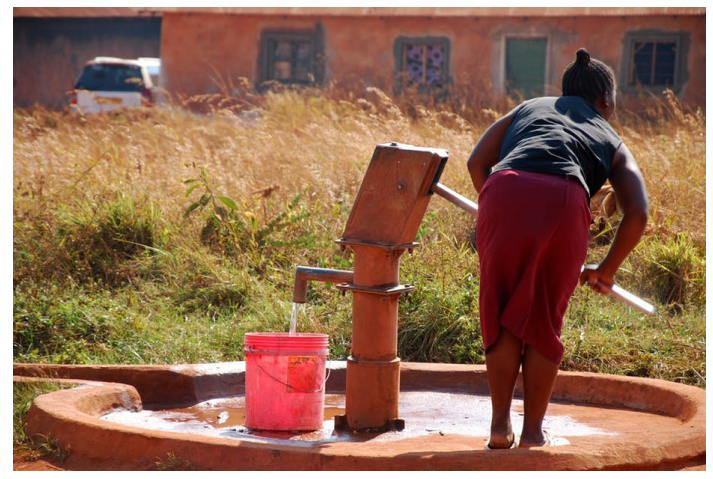

Сл. 7. Водна инсталација во Африка

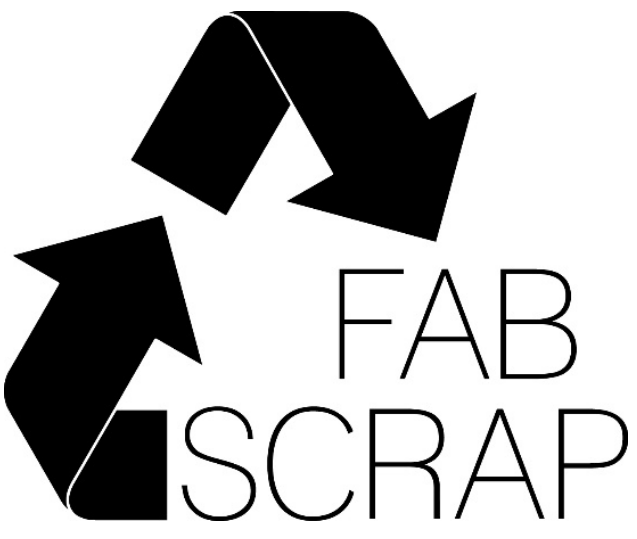

Сл. 6. Лого на компанијата

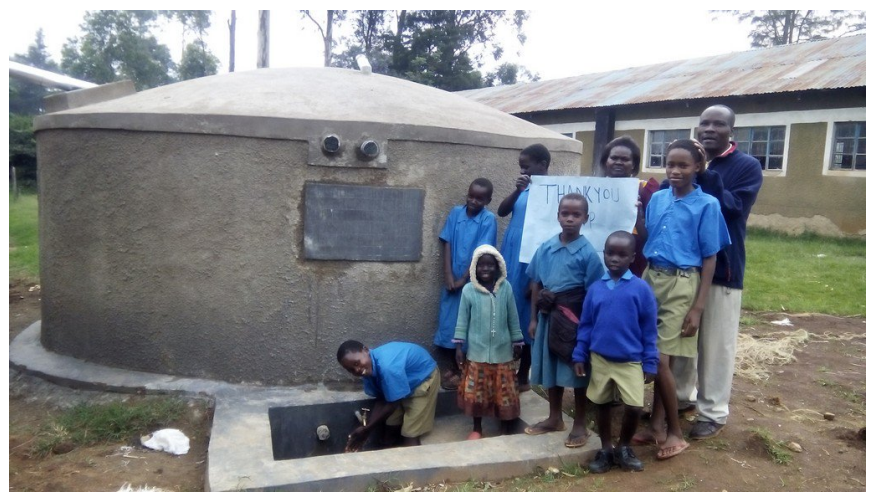

Сл. 8. Водна инсталација во Африка 


\section{2. Актуелни проблеми во современото општество}

Човештвото низ историјата има откриено начини како да функционира ефективно, продуктивно и хармонично во заедништво. Тие заедници имаат прераснато во општества кои може да се опишат како групи на луѓе со заедничка територија, интеракција и култура. Друга дефиниција би била како економска, социјална, индустриска, културна инфраструктура, составена од различни групи на индивидуалци. Иако историски гледано човештвото се има развиено многу и има направено голем прогрес, сеуште има проблеми кои го „повредуваат“ модерното општество. И покрај тоа што вината многу ретко ја носат индивидуалците, социјалните проблеми се многу чести и можат да бидат од различна природа. Социјален проблем најлесно би се опишал како проблем кој засега голем број на индивидуи во едно општество. Најчесто е последица од фактори многу поголеми од индивидуалците и е извор на конфликти и различни мислења. Општествените проблеми можат да бидат од различен тип, социјална сатисфакција, економски проблеми, општествена дезорганизација, јавно здравство, општествена нееднаквост, образование, околина, рециклирање итн. [43].

"Социјален проблем е генерички израз (термин) кој се однесува на спектар на услови и девијантни однесувања кои се манифестација на социјална дезорганизација. Tоа е состојба која многу луѓе во општеството ја гледаат како непосакувана и сакаат да ја променат преку мерки на социјален инженеринг или планирање." - Речник на Оксфорд за Социологија , 1994

Социјалните проблеми се дефинираат преку следните аспекти:

1. Состојба или ситуација осудена како непристојна од значаен број на луѓе.

2. Се смета за непосакувана поради штетни последици.

3. Сите социјални проблеми имаат потреба од подобрување преку колективна акција. Наложуваат промени преку социјален инженеринг.

4. Секое несоодветно однесување или девијација од прифатените норми се смета за социјален проблем, како криминал, деликвентност, проституција итн.

5. Социјалните проблеми не се постојани, напротив тие се менуваат во време и простор. Промените во законот го менуваат и концептот на социјален проблем.

Препознавање и дефинирање на социјален проблем се две различни работи. Понекогаш може да дојде до несогласување ако одредена група има мислење дека одредени ситуации или состојби се непосакувани, но исто така неизбежни поради тоа што се дел од развојот на човештвото или цена која се плаќа за некаков вид напредок. Добар пример за ова е нарушување на рамнотежата во природата кој се создава при сечење дрва заради изградба на патишта итн. [29]. Социјалните проблеми се појавуваат поради разни фактори:

- бидејќn модерните општества се многу комплексни, со измешана внатрешна структура,

- поради фактот дека некои групи ги уживаат бенефитите на општеството, а некои не,

- $\quad$ поради постоењето континуирани социјални промени кои ја менуваат и структурата и воспоставуваат врски помеѓу социјалните групи 


\section{3. Еколошки општествени проблеми}

Еколошките и социјалните проблеми може да се манифестираат на различни начини и да имаат голем ефект врз развојот на човештвото, како и благосостојбата на живите суштества. Во последните неколку децении интересот за еколошката состојба се има значајно зголемено. Големиот притисок кој го претрпе светскиот еко систем имаше големо влијание врз развивањето на свеста кај човекот. Денес на малку поинаков начин се гледа на неговата значајност, добрата, услугите, нарушувањето на биодиверзитетот и потребата за адаптирање во променети климатски услови [8].

Моментални или долготрајни промени во атмосферата, водата, земјата, поради човечки активности, резултираат со влијанија кои се се' потешко поправливи. Општествените проблеми од овој тип најчесто се раѓаат со активностите на разни бизниси или инвеститори кои имаат влијание на околината и општеството. Пример: квалитетот на воздухот, користењето на необновлива енергија, отпадни води и квалитет на водата за пиење, користење опасни материјали, загадување на земјиште, биодиверзитет и природни ресурси, работа и работни услови, професионално здравје и безбедност, општествено здравје, безбедност и сигурност, откупување земјиште и отселување, културно наследство итн. [44].

Според научен труд објавен во "Schooled by science “ во март 2019 година [30], најголемите и најзагрижувачки еколошки проблеми во денешно време, чии последици не можат да бидат игнорирани, се следните:

\footnotetext{
- $\quad$ Менаџирање на земјиште и урбано ширење

- Отстранување на отпад (сл.9)

- Пренаселеност

- $\quad$ Загуба на биодиверзитет

- Недостиг на вода и загадување на водата

- З Загадување на почва

- $\quad$ Уништување на шуми

- $\quad$ Загрозени екосистеми и видови

- $\quad$ Климатски промени(сл.10)
} 


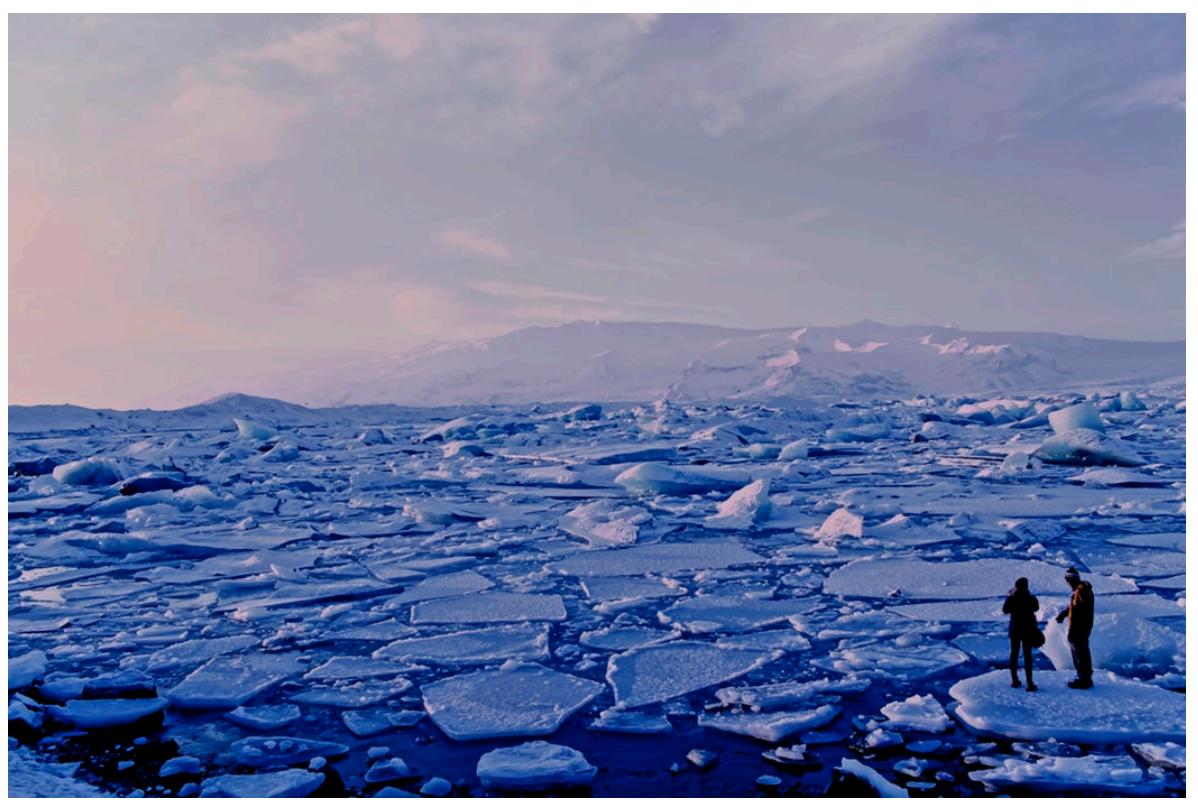

Сл. 9. Топење на мразот поради климатските промени

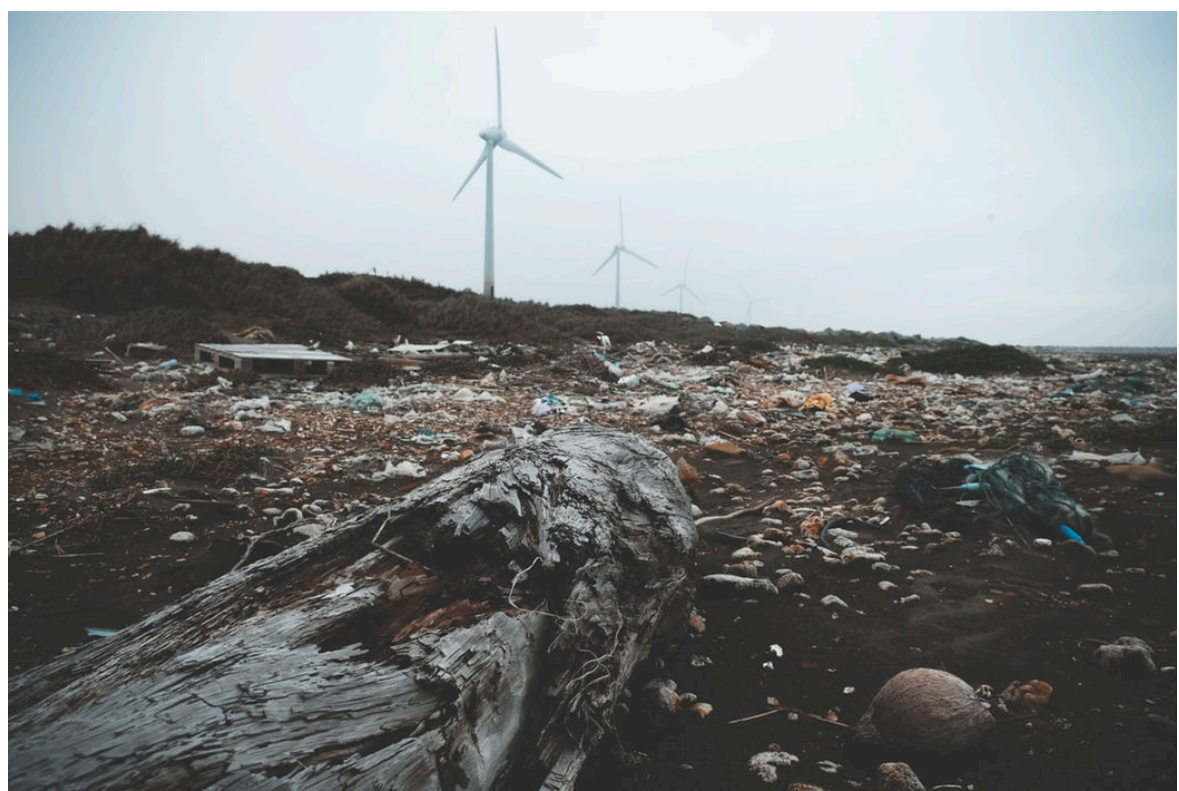

Сл. 10. Загадена животна средина 


\section{4. Решавање проблеми поврзани со животната средина}

"Проблемите со животната средина се присутни и претставуваат предизвик за решавање. Многу комплексни, полни со несигурности и екстремно политизирани" -Лиса В. Брдвел [11]

Историски начинот на истражување се менувал многу, почнувајќи од базични факти до трансдисциплинарни истражувања за решавање некаква еколошка ситуација. Трансдисциплинарните истражувања се прават за идентификување и проучување на даден проблем и факторите кои влијаат врз него. Се базира на интеграција на повеќе дисциплини и активна инклузија на учесници од различни општествени сектори во процесите. За да се има успех во ова поле важно е да се земат во предвид глобалниот (биофизички), социјален и човечки систем истовремено. Вклучување на сите системи подразбира почитување на потребите и интересите на сите, како и поврзаноста со регионални, национални, интернационални нивоа на општествени управување. Во овие процеси човечкиот систем ги претставува здравјето, прифатените норми и вредностите. Медиумите и другите експресии на општество се круцијални за разбирање на еколошкиот и социјалниот процес, менаџирање со природни ресурси, управување и последиците по здравјето и однесувањето на јавноста [10].

Како повеќето социјални проблеми, така и тие кои се однесуваат на животната средина изгледаат екстремно комплексни бидејќ не се добро структурирани. Карактеристично за овој тип на предизвици е дека секое решение со себе носи и нов спектар на проблеми. Во вакви случаи често ризикот е многу голем, а последиците од постапките се неповратни и долготрајни [9].

Наоѓање решенија за оваа категорија проблеми значи многу повеќе од наоѓање само техничко решение, поради тоа што секој избор кој се прави има влијание врз политички или социјални вредности, како и научни очекувања. Одлуките зависат од приоритетите, или „пазарење“ кои ние како општество одлучуваме да го избереме. Тие имплицираат кои ризици и какви промени сме спремни да прифатиме, а што да жртвуваме.

Tоа што особено ги прави комплексни овие проблеми е инкорпорирањето на диверзитетот, разни перспективи на гледање, фактот дека никогаш на крај нема сите да бидат задоволни, нешто ќе треба да се жртвува.

Сознанието дека постојат ситуации кои може да се опишат како ургентни, комплицирани, големи, поставени над индивидуалната моќ, е често многу поразително. За жал повеќето општества имаат недостаток на ентузијазам, мотив, посветеност за справување со нив, наспроти тоа што се очекува од нив [11]. 


\section{3. КРЕАТИВНОТО РАЗМИСЛУВАЊЕ КАКО ОСНОВА НА ДИЗАЈНОТ И ДИЗАЈНЕРСКИОТ НАЧИН НА РАЗМИСЛУВАЊЕ}

Зборот „дизајн“ се користи на толку различни начини што понекогаш е тешко да го дефинираме неговото вистинско значење. Во една од многуте дефиниции се претставува како прогрес, концептуализирање и креирање на нови работи, идеи, интеракции, информации, објекти, производи, места, знаци, системи, услуги и многу повеќе.

“Дизајнот не може да се држи во рака. Не е предмет. Тоа е процес. Систем. Начин на размислување"- Боб Гил [20]

Дизајнот е процес кој ги зема во предвид сите гледни точки, но го става корисникот на прво место и го фокусира развојот според барањата или потребите на таргет групата. Има многу големо влијание врз секојдневието и тоа може да се забележи во најмалите работи кои не опкружуваат и ни го олеснуваат живеењето. Сепак, дизајнот игра важна улога и во еволуцијата на човештвото, развојот на општествата, новите технологии и подобрувања и развој во сите полиња на човековото делување.

Поради разновидноста на областите каде се применува, дизајнот може да биде поделен во неколку категории:

- Дизајн во уметноста - каде границата помеѓу двата поима (дизајн -уметност) е многу тенка. Повеќе се однесува на естетскиот аспект и во ова поле дизајнот претежно се користи за искажување на мислење, филозофија или како декоративна алатка.

- Дизајн како компонента во инженерството - со големо значење во решавањето проблеми. Процесите и методите кои се користат во оваа сфера се екстремно ефикасни и продуктивни.

- Дизајн во производство - како процес на планирање и спроведување на процесите на производство. Тука дизајнот помага во решавањето проблеми во врска со реализација на производството, преку креирање постапки и процеси на планирање.

Дизајнот може да биде и само идеја, план, кој не вклучува физички производ или инженерски процес, но има некаков важен импакт во општеството или за одредена група на луѓе, и се нарекува „дизајн со општествено влијание“. Овој поим најчесто се категоризира како истражување институции, системи (економски, социјални, политички), заедници или поединци, за да дефинира можности за промена или помагање на маргинализирани членови во општеството и нивно активно вклучување во решавање на сопствените проблеми.

Оттука може да заклучиме дека во денешно време дизајнот ги има надминато традиционалните очекувања финалниот резултат да е физички производ и дека истиот може да биде сложен процес на планирање, развој, иновација, решение или промена. 


\section{1. Креативно размислување}

„Ментален и социјален процес кој се користи за генерирање идеи, концепти и асоцијации кои водат до истражување на нови идеи, или со еден збор: иновација.", Рајан Меј [37]

Покрај тоа што овој концепт, најчесто погрешно, се поистоветува со артисти, уметници, писатели, изведувачи, сепак е само начин на пристапување кон даден проблем или ситуација, од различни перспективи.

Познат како „дизајн размислување“ претставува комплексен, но многу важен процес во справувањето со некаков предизвик. Се базира на креативни стратегии, планирања, истражувања, анализи и многу други методи кои доведуваат до решенија. Целосно е фокусиран кон наоѓање солуција преку логика, имагинација, интуиција, резонирање и истражување разни можности за тоа што може да доведе до посакуваниот резултат.

Со овој тип на размислување, се идентификуваат и истражуваат сите познати и непознати аспекти на дадената ситуација, со цел откривање параметри и алтернативни решенија кои водат до задоволителни цели. Разните методи и фази кои се користат, помагаат во надминување на стравот од неуспех и охрабруваат давање и прифаќање идеи од што повеќе различни извори [25].

Дизајн размислувањето или креативното размислување во модерниот свет, се користи во разни сфери на човековото живеење, а во последно време тоа е посебно популарно во работата на бизнис компаниите.

Претставуван и како глобално модерен начин на размислување со моќ да трансформира, има големо влијание врз тоа како успешни организации ги решаваат своите проблеми. Му се дава голема предност бидејќ е секогаш фокусиран кон човекот за наоѓање иновативни вистински решенија за тешки проблеми. Комбинација на дизајн, менаџмент и наука која се користи за развој на производи, услуги и искуства, како и бизнис стратегии е важна способност за станување најдобар во одредена сфера [25].

Авторот Томас Локвуд, во својата книга „Дизајн размислување: интегрирање иновација, искуство на потрошувачите и вредност на бренд“, вели дека индустриските дизајнери се конечно ослободени од нивните ограничени обврски на стилизирање производи или нивна иновација. Нивната креативност и начин на размислување се искористува и за стратегии, во насока на дизајнирање искуства, услуги, бизнис модели и слично. Потврдено е дека овој процес на размислување дава резултати кои носат голем профит за компаниите, поради што и дизајнерите се сметаат за коренот на агилноста на една компанија. Локвуд агилноста ја објаснува како вистинскиот ментален склоп, јаки вештини и страст за работа [2].

Сепак, многу автори избегнуваат да дадат конечна дефиниција за дизајн размислувањето за да не создадат погрешна слика или несакајки да го претстават како едноставен процес. Честопати на него реферираат како на начин на работа на еден дизајнер и како тој го разбира дизајнот. 
Процесот на креативното размислување се одвива на тој начин што тим од дизајнери (или други лица со креативни способности) преку примена на разни методи целат да решат даден проблем или ситуација, и да им помогнат на тие кои имаат потреба.

Поради предностите на процесот, имало многу голем интерес за тоа дизајнерскиот начин на размислување да се сведе на принципи кои можат да бидат учени и користени од недизајнерите. Тоа е остварено преку воспоставување неколку клучни елементи кои се меѓусебно зависни и многу динамични и треба да се следат при процесот на истражување. Но, како овие елементи ќе бидат искористени зависи од дизајнерот/те и од контекстот.

Овие принципи се посебно погодни за небулозни ситуации каде проблемите не се добро формулирани, клучните информации се конфузни или непостоечки, или е тешко да се предвиди какво влијание би имале промените. Со ова се овозможува поголема иновативна слобода на дизајнерите при структурирањето, реформулирањето и третирањето на проблемите, оставајќи простор за покреативни пристапи. Повторување, анализирање, ревизија и најважното поставувано прашање -“ Што ако?“" - ја имаат главната улога за предвидување на последиците и генерирањето нови идеи и солуции [2].

\section{2. Процес на дизајнирање}

Дизајнерските процеси вклучуваат висок степен на контролирана креативност, насочена кон продуцирање остварливи, практични решенија на даден проблем. Постојат поголем број разработени методологии за процесот на креативно размислување составени од 4, 5 или повеќе чекори. Преку овие чекори се лоцира проблемот, се поставуваат вистинските прашања, се креираат идеи, се охрабрува размислување 'out of the box', и се избираат најдобрите одговори. За реализација на процесот на дизајнирање се применуваат голем број креативни техники, карактеристични за различните фази. Редоследот на чекорите може да биде променет за поефикасни резултати. Како пример може да се земе методот предложен од Хасо-Платнер Дизајн Институтот во Станфорд [39] кој содржи 5 фази, презентиран преку дијаграмот бр. 1.

Прва фаза : Емпатија

Прва и многу важна фаза во која дизајнерите не треба да се водат според нивните претпоставки и интуиција за дадена ситуација, напротив, треба да се обидат темелно да го разберат дадениот предизвик. Целта е да се истражува што повеќе и се оствари емпатија кон афектираните, како и подобро разбирање на потребите на таргетираната група. Ова е особено важно кога се решава социјален или општествен проблем, кој има потреба од креативно решение. Во оваа фаза е потребно внимателно студирање на дадената област, опсервирање, поврзување/зближување со жртвите како и нивно вклучување во процесот, со цел да се разберат нивните искуства и мотивации подобро.

Искусување на физичкиот амбиент/атмосфера од самите дизајнери, заради подлабоко персонално разбирање и согледување на ситуацијата е приоритет во оваа фаза, бидејќи тие треба да направат истражување за : 
- откривање што е значајно и вредно за целната група;

- препознавање на неискажаните потреби и желби;

- запознавање на светот од перспективата на корисниците / „жртвите“

Втора фаза : Дефинирање

Самиот наслов асоцира дека во оваа фаза се дефинираат карактеристиките, функциите, и други елементи кои доведуваат поблиску до можното решение. Прецизно систематизирање на истраженото и собраните податоци, воспоставување структура како понатаму ќе се одвива процесот. Но, доколку предизвикот е доволно едноставен и дефинирањето прецизно, тоа може да резултира со наоѓање на решението со минимален напор, во самата фаза дефинирање. Сите собрани информации се анализираат детално за да се дефинира коренот на проблемот.

Трета фаза : Генерирање идеи

Во оваа фаза се врши генерирање идеи, идентификување нови решенија на претходно дефинираниот проблем и разгледување на работите од што повеќе различни гледни точки. „Brainstorm“ сесии, како и разни сценарио техники, се користат за стимулирање на слободно размислување и проширување на проблемот. Се наложува дека е најдобро да се генерираат сите идеи и решенија на самиот почеток на оваа фаза. Исто така, многу е важно сите да се чувствуваат слободни и да се елиминира стравот од давање погрешна идеја или можноста за неуспех.

Четврта фаза : Прототипирање

Фаза во која се произведува пробна верзија, со минимален трошок, на самото решение или дефинираните карактеристики, со цел да се истражат избраните идеи и информации од претходните чекори. Ова е експериментална фаза и целта е да се најде најдобриот одговор за секој идентификуван проблем посебно. Сите солуции се имплементирани во прототипот и внимателно испитувани. Тие или се прифаќаат, подобруваат, испитуваат одново или се одбиваат врз основа на искуството на корисникот.

Петта фаза : Тестирање

Овозможува редефинирање на проблемот. Избраниот прототип ригорозно се тестира, како и целосниот производ, користејќи ги најдобрите решенија детерминирани во претходните фази. Важно е да се прифатат сите критики и коментари и да се тестира повеќе пати, воедно внимателно да се опсервира однесувањето на корисниците или ситуацијата [27]. 


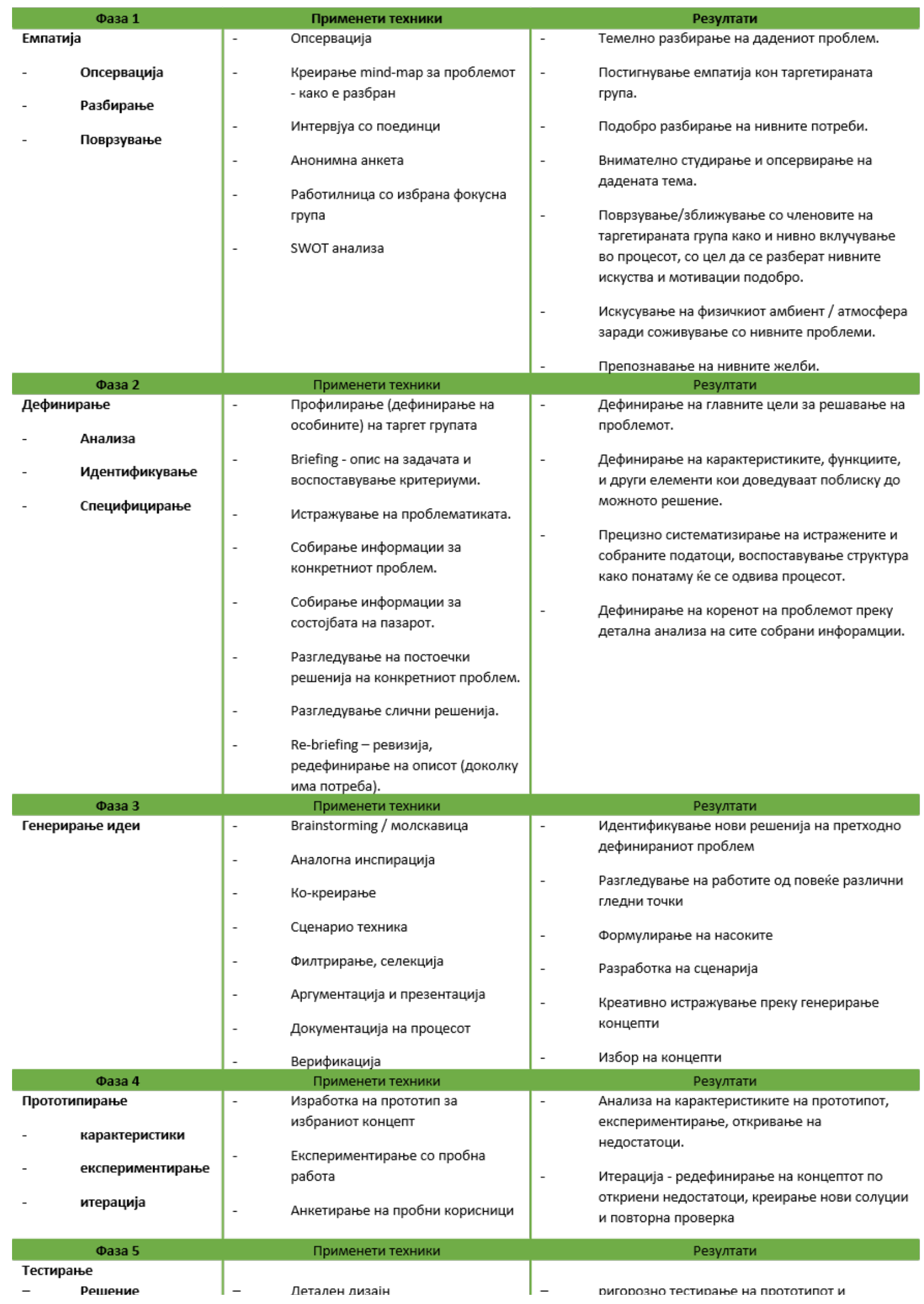




\section{Истражување}

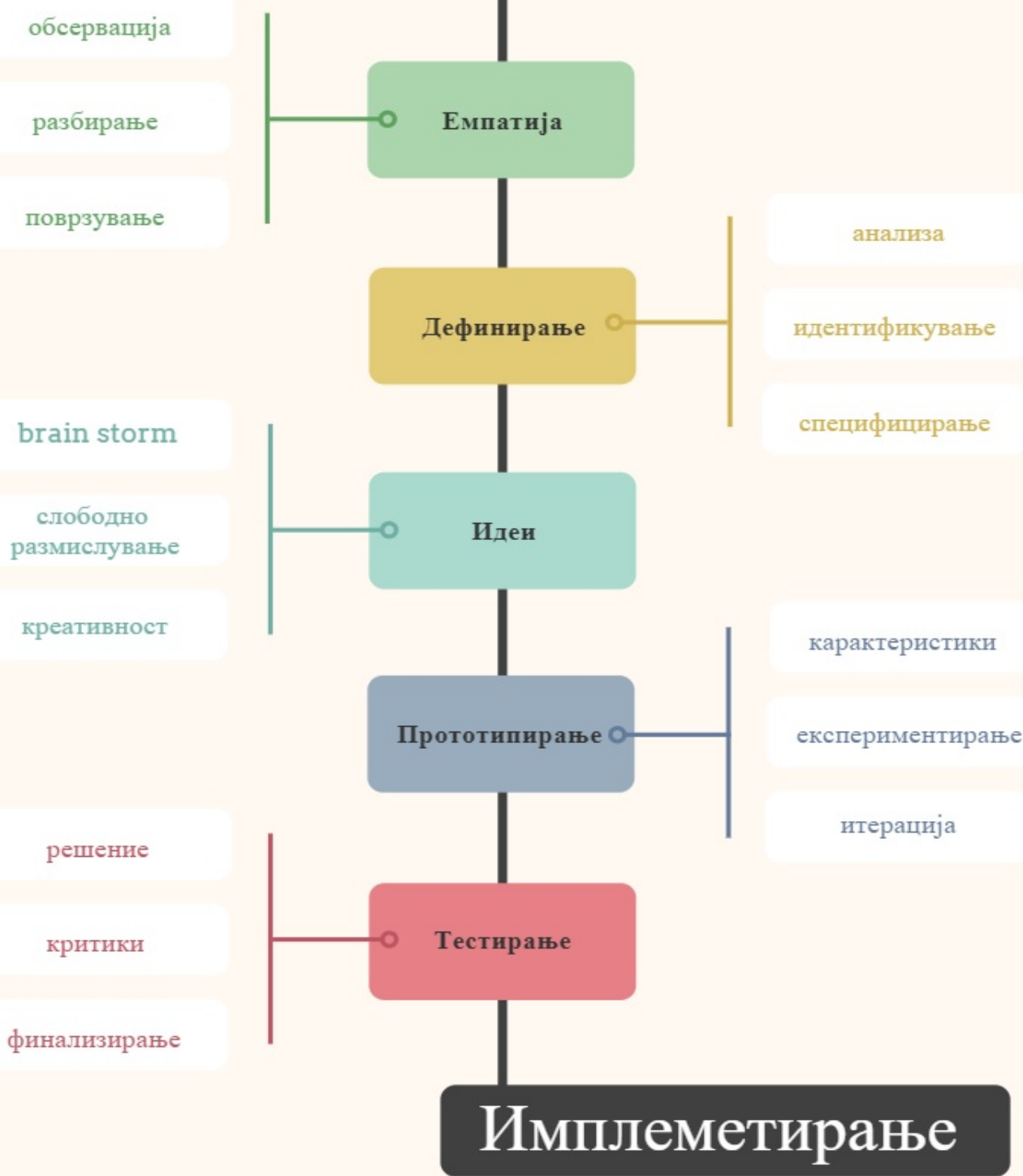

Дијаграм бр.1 Пет фази на процесот на дизајнирање 


\section{3. Процес на дизајнирање во решавањето проблеми од општествено значење}

Дизајнерското размислување е добро познато во комерцијалниот сектор, но е многу потребно во општествениот сектор. Општествениот сектор секогаш се соочувал со разни проблеми кои имаат потреба од темелно решавање користејќ ги сите можни алатки. Потешкотиите во здравството, образованието, земјоделието, транспортот, социјалните услуги и слично имаат потреба од креативни соработки, кои можат да ги променат и најзакоравените бирократски институции [21].

Целокупната структура на еден проект во кој се применува пристап на дизајн со општествено влијание има многу покомплексна структура и содржина од вообичаениот проект за дизајнирање. Како резултат на стекнатите искуствата од едукативниот и истражувачкиот дел на проектот „Дизајн со општествено влијание“ кој беше реализиран како соработка помеѓу Универзитетот за применети уметности од Цирих, Швајцарија и Машинскиот факултет во Скопје во периодот 2015-2017 година [19], изведени се заклучоци кои се однесуваат на разликите помеѓу вообичаениот процес на дизајнирање и оној во кој е применет пристапот на дизајн со општествено влијание.

Вообичаениот процес на дизајнирање започнува со јасно дефиниран и очигледен проблем, каде клиентот најчесто не соработува со дизајнерот. Синџирот на вредности е однапред дефиниран. Целиот процес е праволиниски и под контрола на дизајнерот. Се одвива со примена на пристапот одгоре-надолу, поточно воден е од прецизно зацртани цели од самиот почеток, воспоставени врз база на извршени истражувања од засегнатата област.

За разлика од вообичаениот процес на дизајнирање во еден проект со општествено влијание проблемот на почетокот е нејасен, непрепознаен. Процесот се одвива по принципот оддолу-нагоре, поточно се тргнува од проучување на заедницата, начинот на живот, а конкретниот проблем треба да се препознае преку заедничката работа на дизајнерите како креативци и членовите на засегнатата заедница. Овој процес не е праволиниски, честопати е конфузен, нејасен, не се знае кој го води и контролира. Се одвива преку заедничко делување и кокреирање, при што неопходни се знаењата и вештините на сите учесници. Во овој процес голема

улога играат невладини организации чија цел е да се помогне на заедницата во унапредување на нивниот живот во различни аспекти.

Во дијаграм бр.1 е даден преглед на фазите на процесот на дизајнирање во еден проект со општествено влијание проблемот, најчесто применуваните техники по фази и резултатите кои се постигнуваат при тоа. 


\section{4. ПРИМЕНА НА КРЕАТИВНИТЕ ТЕХНИКИ ВО РЕШАВАЊЕ НА ОПШТЕСТВЕНИОТ ПРОБЛЕМ - СПРАВУВАҢЕ СО ОТПАДОТ ВО УРБАНИТЕ СРЕДИНИ}

Врз основа на стекнатите знаења за креативните техники, процесот на дизајнирање и методологијата дизајн со општествено влијание во овој магистерски труд е извршено истражување со цел да се даде придонес кон подобрување на условите за живот во урбаните средини во нашата земја. Во ова поглавје се опишани сите пет фази на креативниот процес спроведен за конкретниот истражуван проблем, според методологијата дизајн со општествено влијание. Процесот е започнат со дефинирање на:

- истражуван проблем од општествено значење - видливи огромни количини на различни видови отпад на улиците во градот Скопје

- таргет група - жителите на градот Скопје

Истражувањето е извршено во пет фази опишани во продолжение. 


\section{1. Фаза 1 - емпатија}

Во првата фаза е извршено запознавање со проблемот преку опсервација и документирање на состојбите, интервјуа, анкетирање и работилница која помогна во соживувањето со проблемите на граѓаните.

\subsection{1. Опсервација}

Истражувањето започна со опсервација на секојдневните навики на граѓаните и нивните проблеми поврзани со отпадот во неколку реони на Општината Карпош и Центар. Состојбите беа документирани преку голем број фотографии (сликите подолу) кои сведочат за лошите навики на граѓаните, но и лошото работење на Институциите задолжени за собирање на сметот.

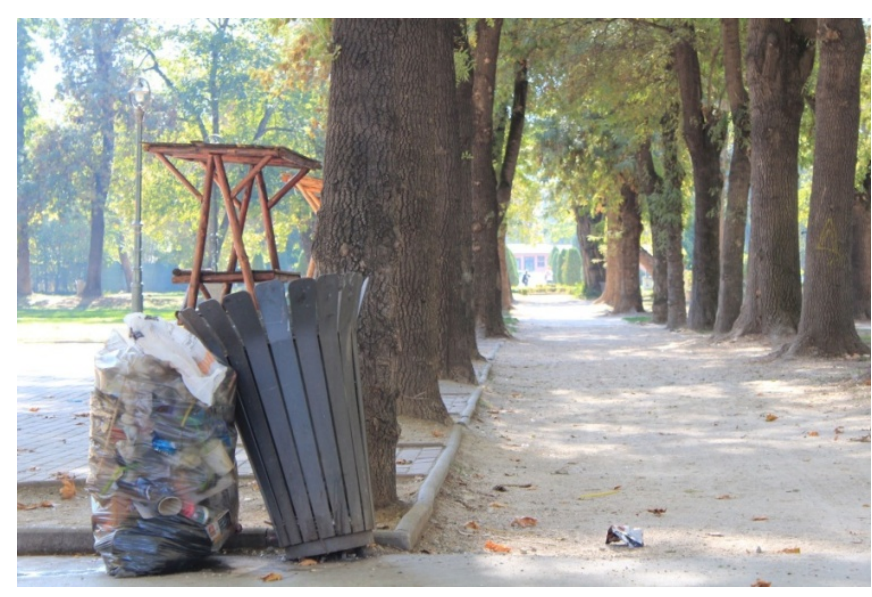

Сл. 11. Отпадот најчесто завршува надвор од корпите

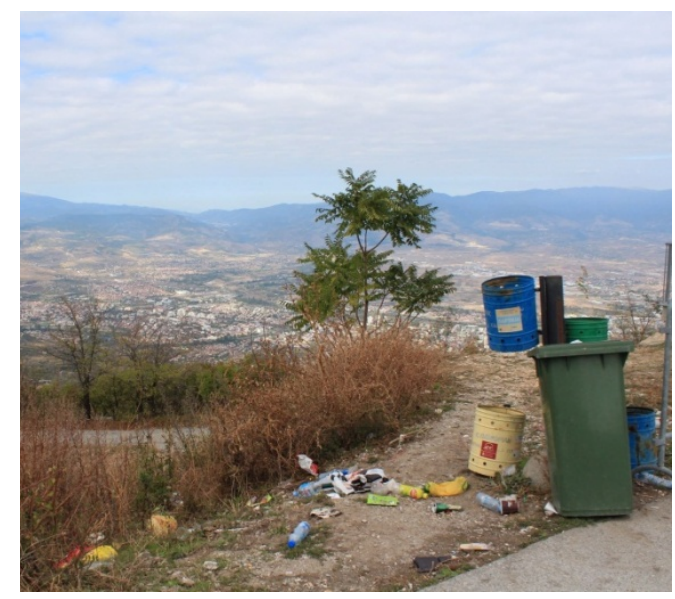

Сл. 12. Отпадот расфрлан надвор од корпите

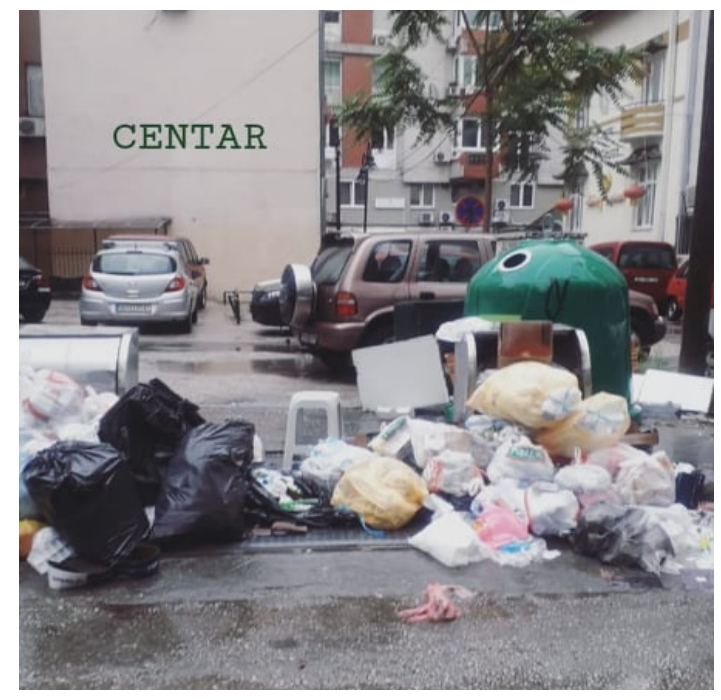

Сл. 13. Отпадот фрлен надвор од контејнерите

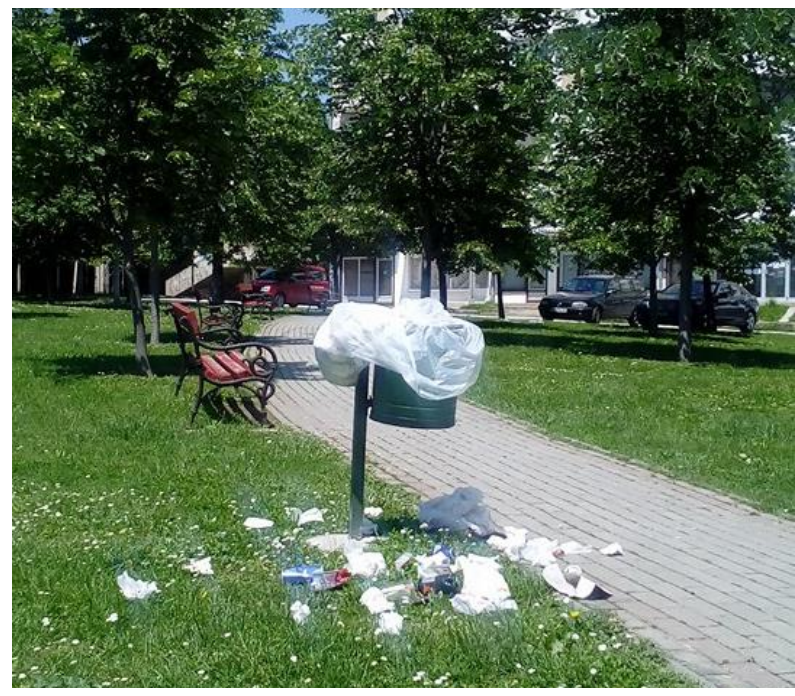

Сл. 14. Отпад околу корпите

И покрај поставените улични контејнери, отпадот најчесто завршува надвор од нив, загадувајќи ја околината. Овој факт зборува многу за свеста на граѓаните за тоа како со нивните неодговорни постапки негативно влијаат на животната средина. 

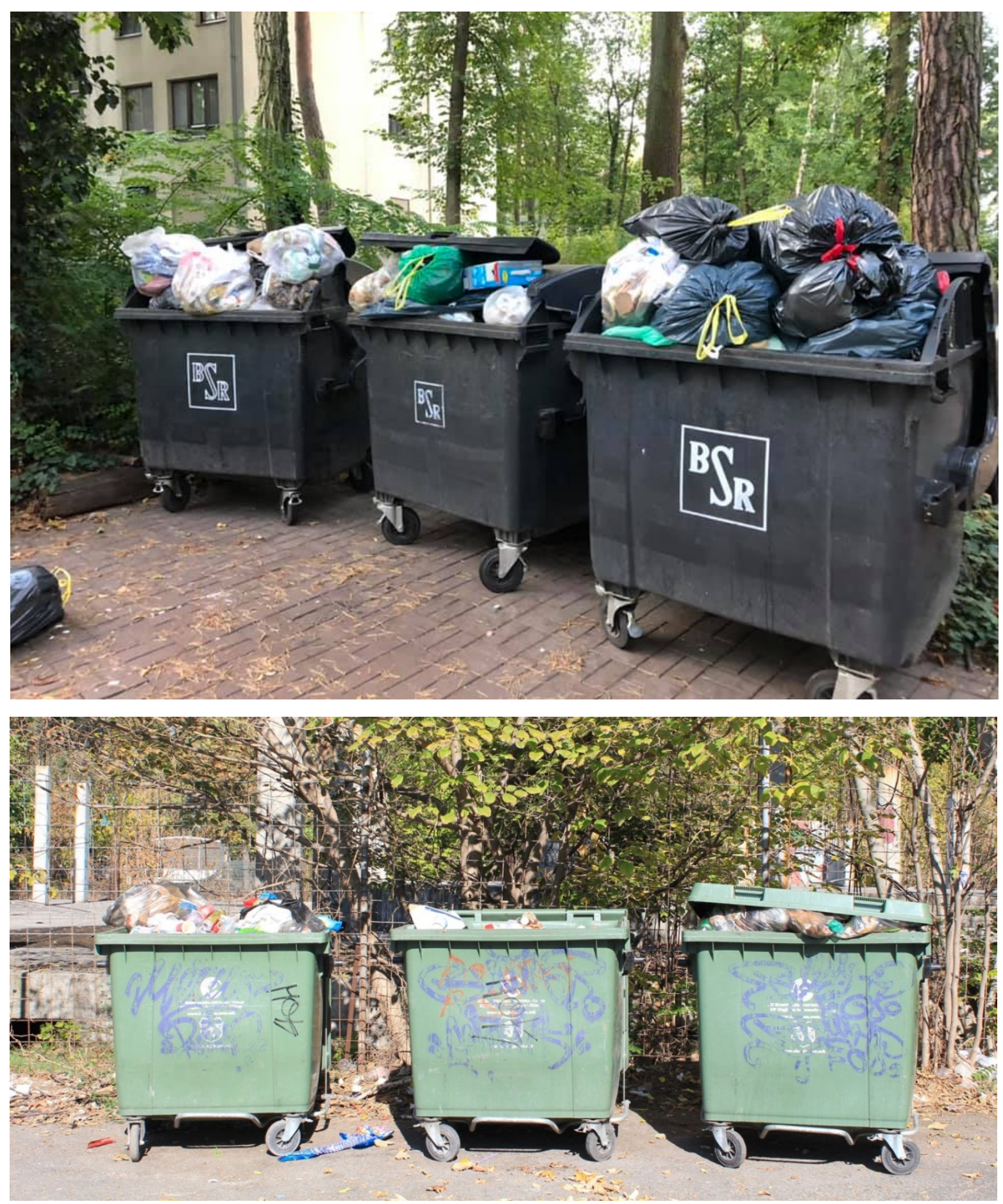

Сл. 15. и сл. 16. Контејнери полни со отпад

Контејнерите се секогаш преполни и отворени поради што отпадот многу лесно се истура од нив. Покрај лошата слика, ваквата состојба овозможува временските услови да бидат фактор во разнесувањето на отпадот низ околината, како и можност за ширење екстремно лоши миризби и зарази од органскиот отпад. 


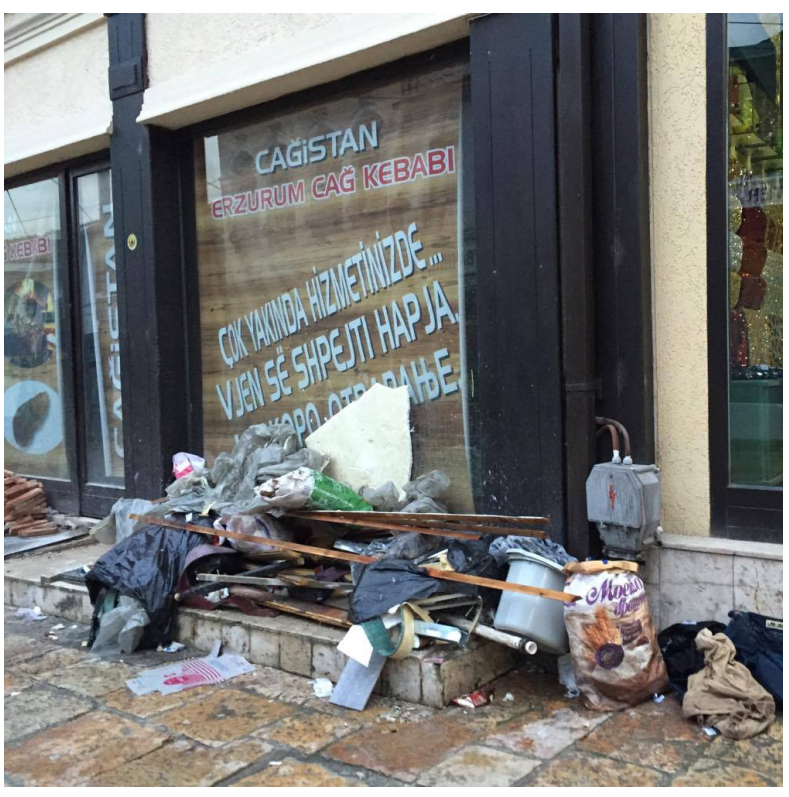

Сл. 17. Отпад на улица

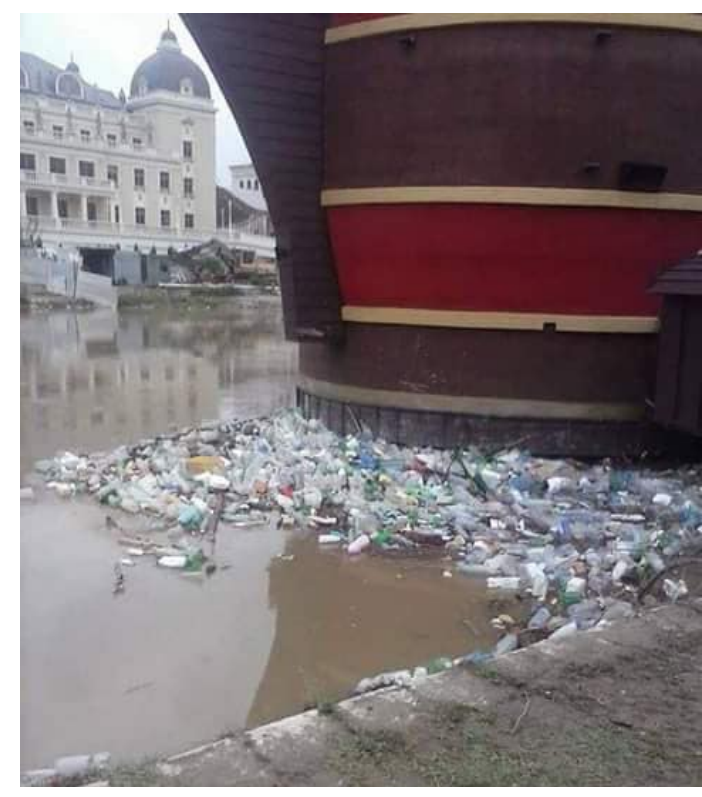

Сл. 18. Отпад расфрлан во реката Вардар

Отпадот е насекаде, дури и на места кои се секојдневно посетени од туристи

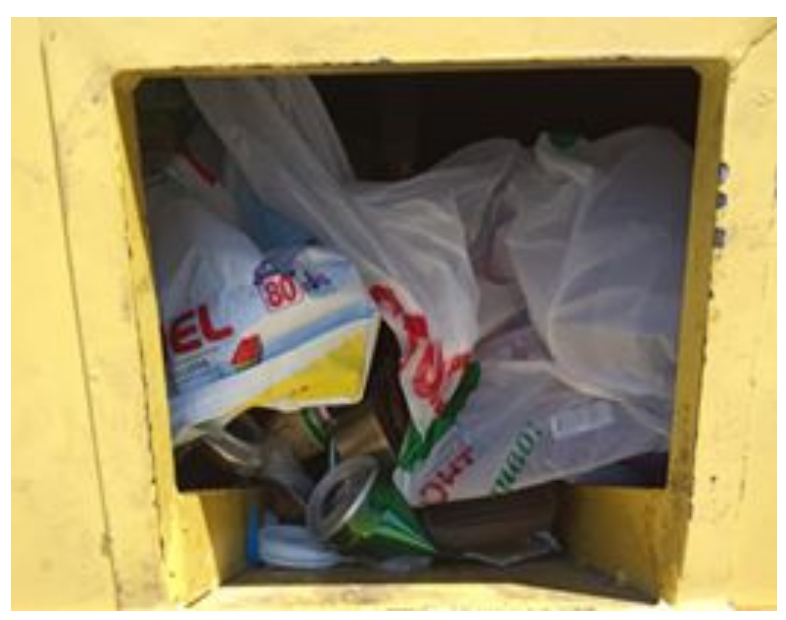

Сл. 19. Несортиран отпад

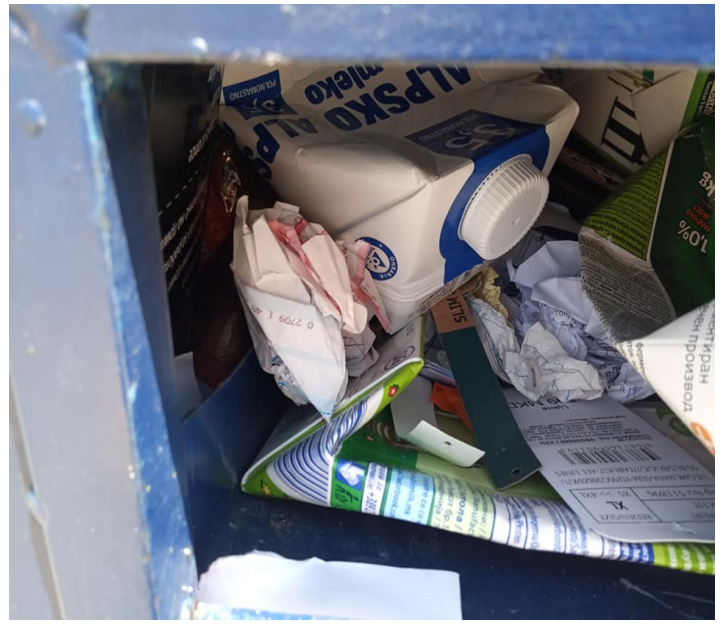

Сл. 20. Обележан контејнер со мешан отпад

Контејнерите за селектиран отпад се реткост во споредба со очекуваното од еден главен град, но и кај тие кои се поставени, иако се обележани, отпадот во нив не е селектиран. 

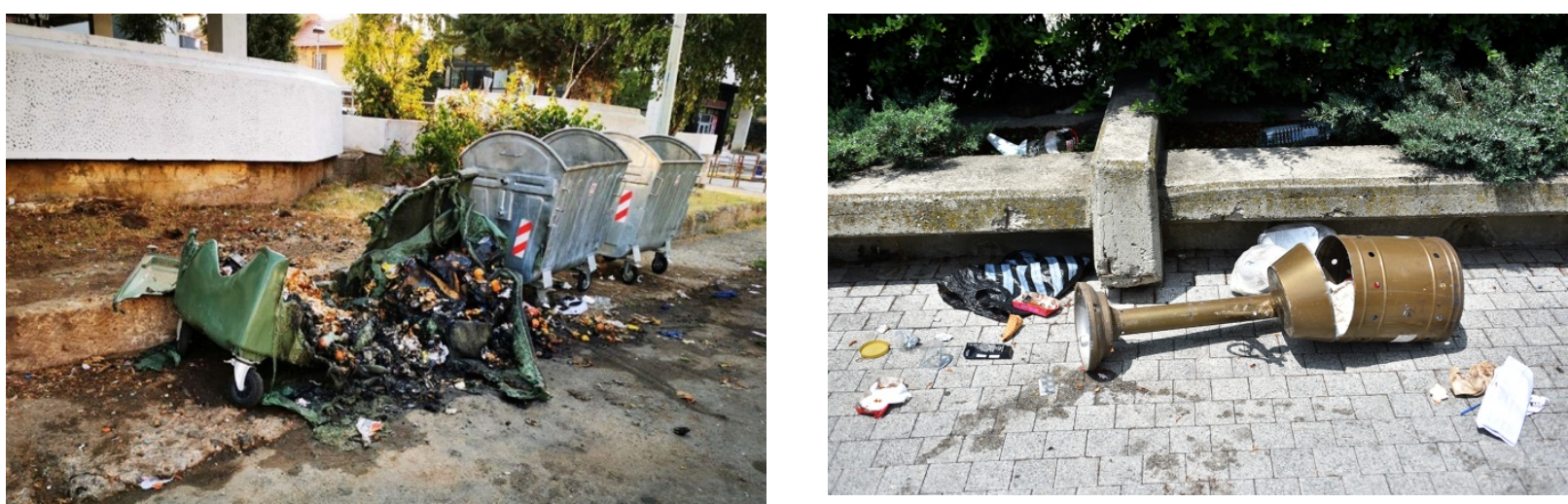

Сл. 21 и сл. 22. Превртени и оштетени контејнери и улични корпи за отпадоци
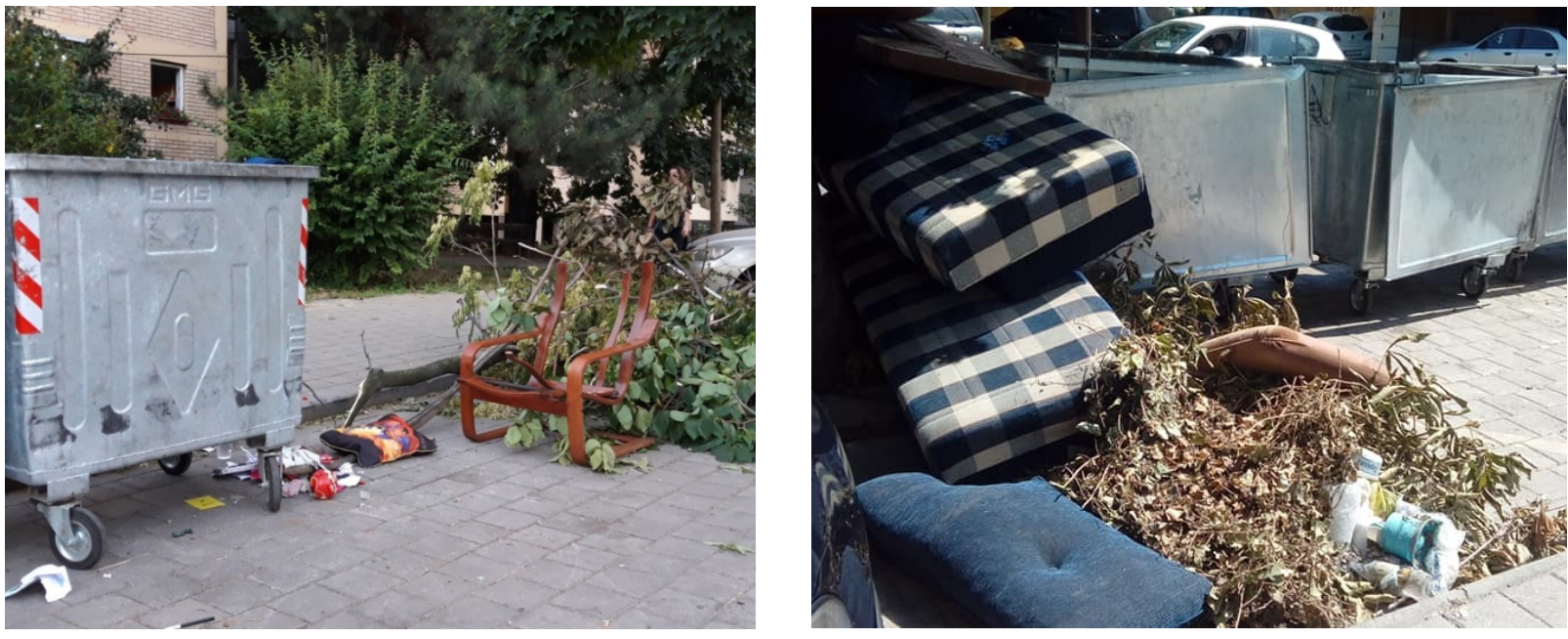

Сл. 23. и сл. 24. Кабаст отпад покрај контејнери

Кабастиот отпад (градежен шут, стар мебел и облека) треба да се одлага во специјални контејнери или директно во пунктовите на Комунална хигиена, но тој скоро секогаш завршува на тротоарите или во близина на контејнерите. Жителите не се доволно информирани за тоа како се одлага кабаст отпад или поради финансиски причини се одлучуваат да ја загадуваат околината (сл.23,24). 


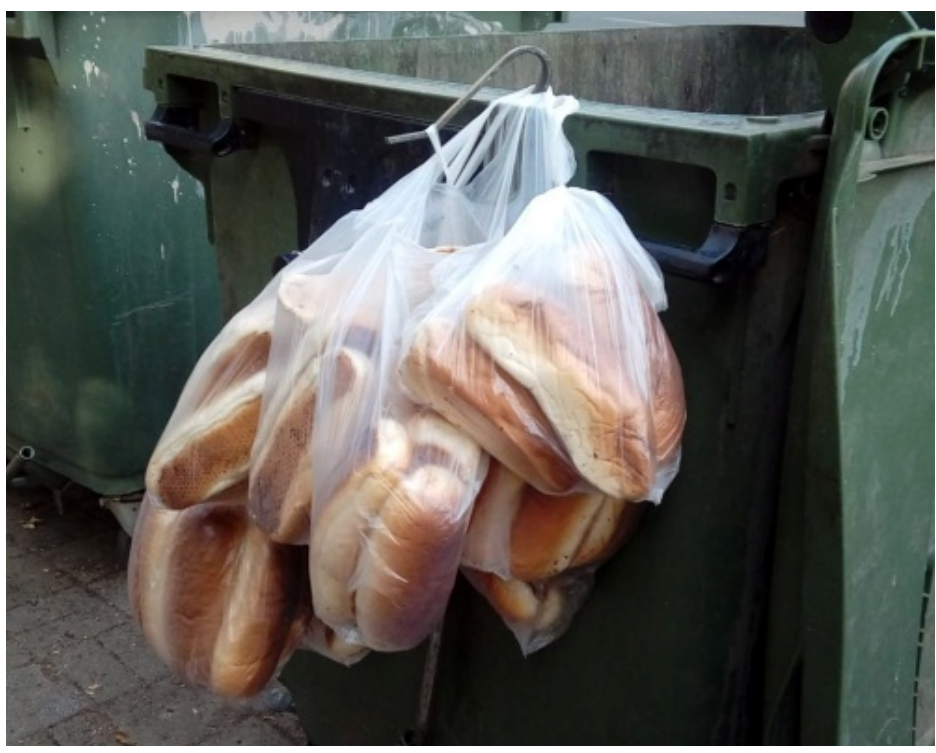

Сл. 25. Храна закачена надвор од контејнер

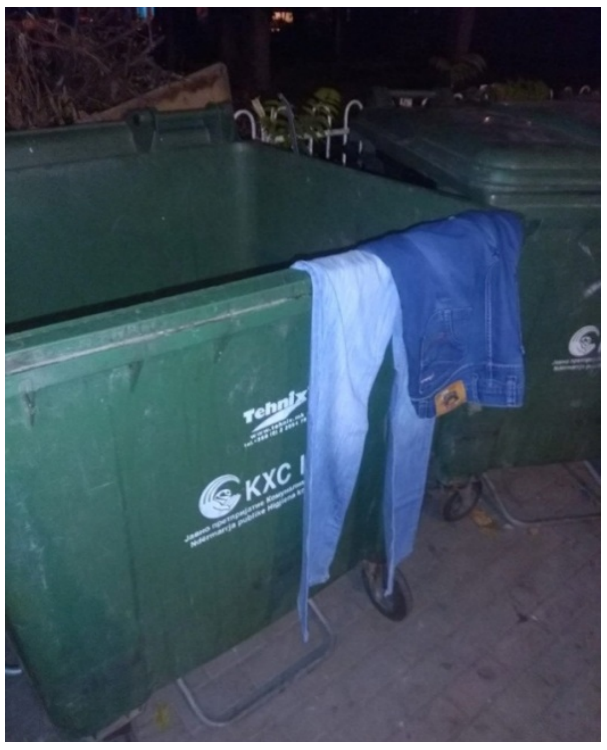

Сл. 26. Гардероба закачена на контејнер

Честа слика се и закачените кеси полни со храна, облека или селектиран тип отпад како висат на контејнерот, иако тоа не е дозволено. Ова честопати го прават со цел да не го мешаат отпадот со сеуште употребливи или реупотребливи продукти, кои некому може да му требаат.

Заклучоците изведени од извршената опсервација се однесуваат на следните аспекти:

- Контејнерите се во 99\% случаи отворени и преполни со отпадоци

- Околу контејнерите многу често има расфрлани отпадоци кои не можеле да се сместат во преполните контејнери

- Улични животни се собираат околу нив

- Се шири многу лош мирис од органските отпадоци

- Многу често се забележуваат парчиња мебел, вреќи шут

- Обележаните контејнери за одлагање селектиран отпад не се почитуваат

- Често пати контејнерите се уништуваат и превртуваат 
4.1.2. Креирање mind-map за проблемот како е разбран

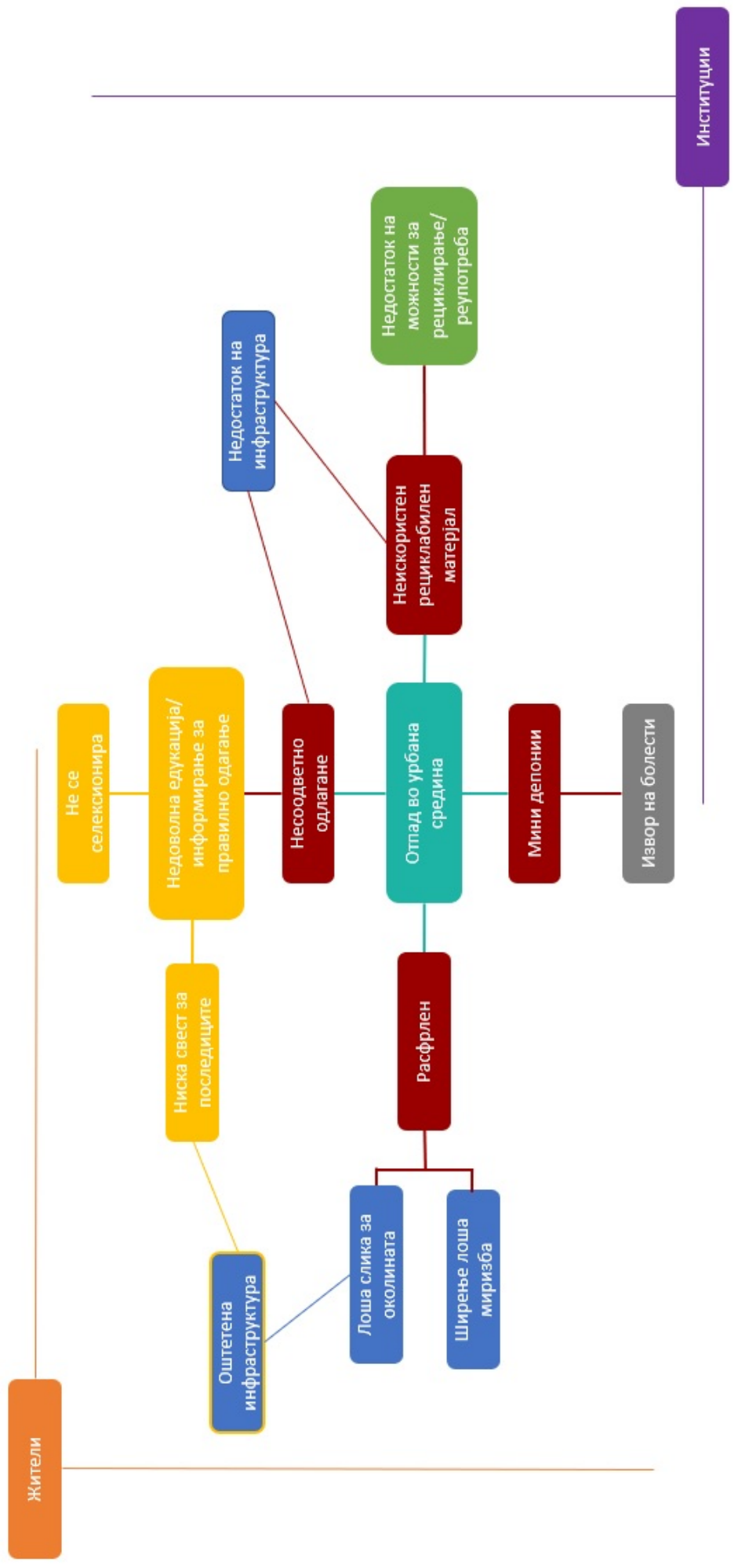

Дијаграм бр.2 Mind map 


\subsection{3. Интервјуа со поединци}

Низ разговори со десетина поединци, жители на Општината Карпош, беа собрани дополнителни информации кои се однесуваат на проблемите на граѓаните во врска со:

- непостоење или неинформираност на граѓаните за начинот како да се отстранат непотребните предмети од домовите (стар мебел, облека, електрични и електронски уреди итн.);

- непостоење или неинформираност на граѓаните за начинот како да се отстрани градежниот шут при реновирање на станови;

- непостоење на собирни центри за донирање и размена на стари предмети;

- несовесно користење на пожарните скали во зградите за отстранување на шут и други непотребни предмети.

\subsection{4. Спроведена анонимна анкета}

Во месец јуни 2019 година беше спроведена анонимна on-line анкета со прашања наменети за индивидуалци, жители на градовите од Македонија со цел да се извлечат заклучоци за нивните навики во отстранувањето на отпадот, нивните ставови и мислења за состојбите со отпадот во нивната животна средина. Резултатите од анкетата се следните:

\section{Табела 1.}

Процентуално учество на испитаници по општини и градови

$\begin{array}{ll}\text { Општина Центар } & 23,4 \% \\ \text { Општина Карпош } & 17,3 \% \\ \text { Општина Аеродром } & 14,5 \% \\ \text { Општина Чаир } & 11,3 \% \\ \text { Општина Кисела Вода } & 9,3 \% \\ \text { Општина Ѓорче Петров } & 7,95 \% \\ \text { Општина Бутел } & 3,4 \% \\ \text { Општина Гази баба } & 2,9 \% \\ \text { Општина Сарај } & 0,7 \% \\ \text { Други градови во Македонија } & 9 \%\end{array}$

91\% од испитаниците беа од главниот град Скопје, додека 9\% од други градови во државата. 


\title{
Дијаграм бр.3
}

\section{Возраст}

151 responses

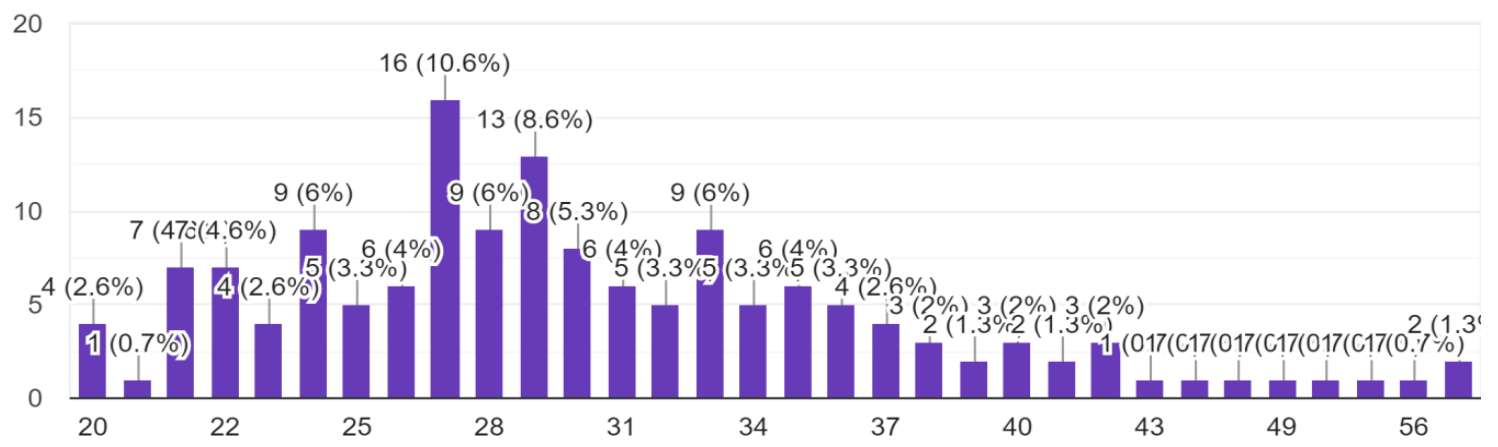

Според возраста најголемиот дел од испитаниците беа помеѓу 22 и 35 години.

\section{Дијаграм бр.4}

\section{Дали го сортирате отпадот во вашето домаќинство?}

\author{
151 responses
}
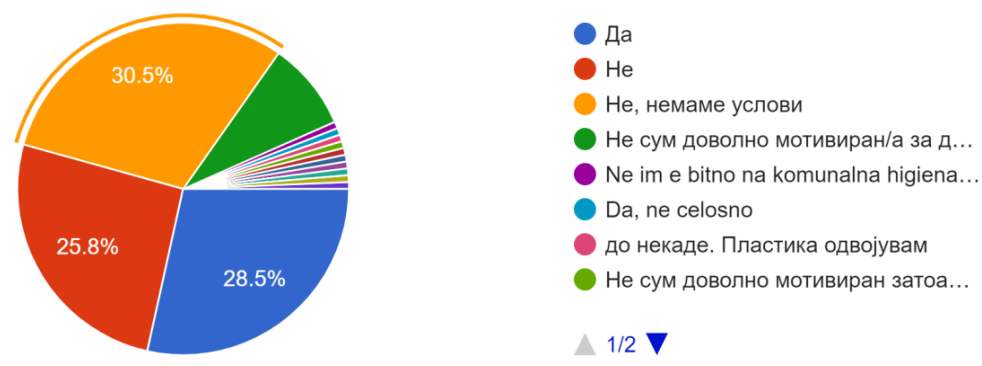

Најголем број испитаници не врши сортирање на отпадот, но сепак процентот на оние кои го сортираат, или барем се обидуваат, покажува дека полека се подигнува јавната свест за овој проблем. 


\section{Дијаграм бр.5}

Доколку одговорот на претходното прашање е „ДА“, како постапувате со одвоениот отпад кога треба да го отстраните?

61 responses
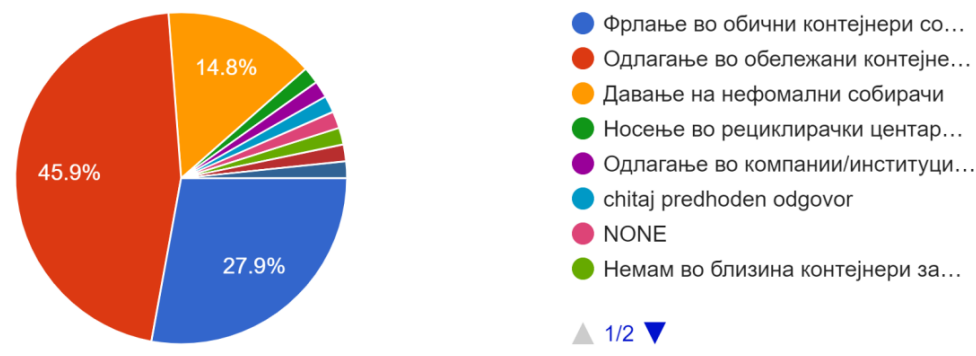

Од испитаниците кои одговориле позитивно 27,9 \% селектираниот отпад го фрлаат во обични контејнери со мешани отпадоци, 45,9\% во соодветно обележани контејнери, додека $14,8 \%$ го даваат на неформални собирачи. Двајца од испитаниците одговориле дека го носат во рециклирачки центар или отпад, само еден го предава на институции кои откупуваат рециклабилни материјали, а еден тврди дека селектира органски отпад поради компостирање.

\section{Дијаграм бр.6}

Дали го сортирате отпадот на работното место/образнова инситицција?

151 responses

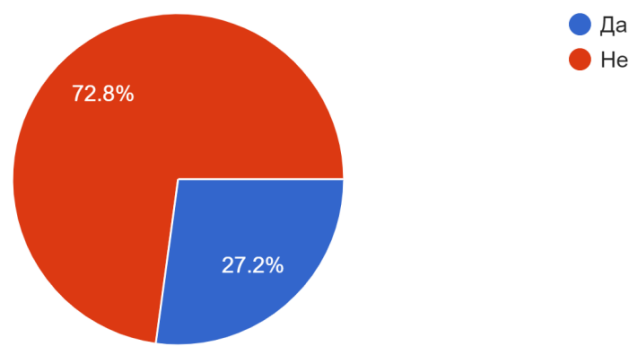

Од 27.2\% учесници кои одговориле позитивно на претходното прашање 5\% тврдат дека компанијата Пакомак е одговорна за отпадот. Истите го собираат во текот на неделата. Други 5\% велат дека отпадот е преземен од компании кои се занимаваат со оваа дејност, меѓу кои беа спомнати и Нула Отпад. 5\% тврдат дека ја рециклираат хартијата, додека 2\% компостираат на работното место, а делумно селектираниот отпад го даваат на неформални собирачи. 1\% тврдат дека медицинскиот отпад го добива соодветниот третман, додека останатите се немаат изјаснето. 


\section{Дијаграм бр.7}

Дали во ваша близина има поставено соодветно обележани контејнери за хартија сталко и пластика?

151 responses
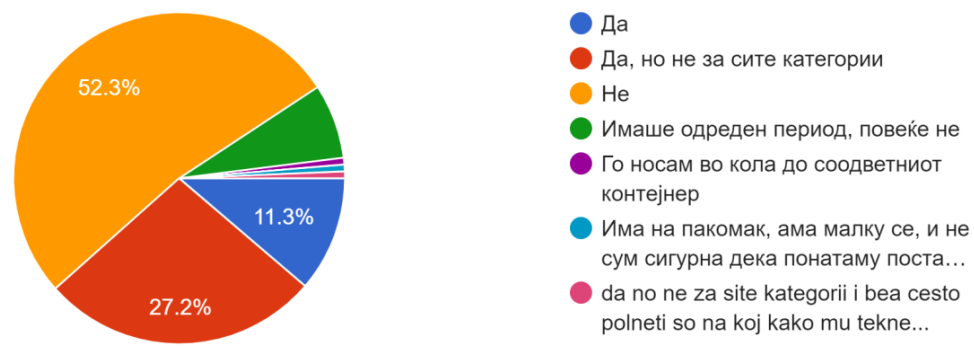

52.3\% испитаници изјавиле дека во нивна близина нема поставено обележани контејнери, додека кај 27.2\% само за одредени категории. 7.3\% тврдат дека имало извесен период кога постоеле контејнери во нивна близина, но подоцна биле дислоцирани. Од ова може да заклучиме дека повеќе од 80\% од испитаниците немаат адекватна опрема во нивна близина што го отежнува процесот на примарно селектирање.

\section{Дијаграм бр.8}

Колку често се наоѓате во ситуација да не знаете како да постапите со одредена категорија на отпад?

151 responses
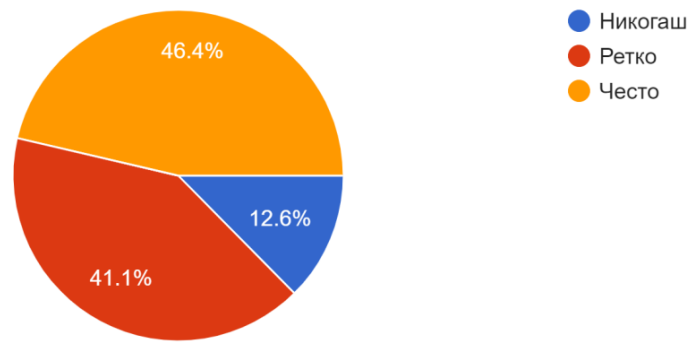

Граѓаните се неинформирани како да постапат со одредени категории отпад. 


\section{Дијаграм бр.9}

Одлагањето на кој тип на отпад најчесто ви претставува проблем?

146 responses

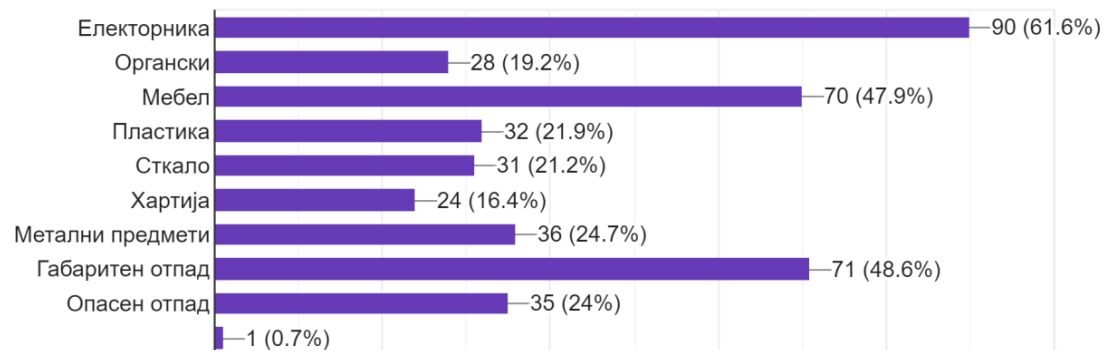

Според испитаниците најпроблематичен отпад е електронскиот а после него, габаритниот отпад и стариот мебел.

\section{Дијаграм бр.10}

Како сте постапувале до сега? (со отпад кој за вас бил проблематичен за одлагање)

151 responses

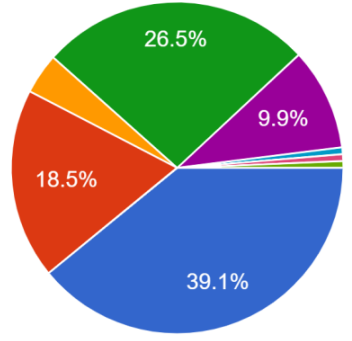

Фрлање во контејнер со мешан отпад

Оставање на улица/во близина на контејнер

Контактирање на институција/ком..

Продавање/поклонување на неф...

Чување дома/во гаража

Електрониката најчесто покрај ко...

1,4 и 5 од понудените одговори

ili go frlam so mesan otpad ili do ko...

39,1\% отпадот кој им преставува потешкотија при отстранување го фрлаат во контејнери со мешан отпад, додека $18,5 \%$ решението го наоѓаат во оставање на улица во близина на контејнерите. Само 4\% имаат контактирано институции кои се занимаваат со оваа дејност, додека 26,5\% го продаваат или подаруваат на неформалните собирачи. 9,9\% го чуваат во нивните домови или гаражи. 


\section{Дијаграм бр.11}

Колку често поклонувате работи кои не ви се потребни?

151 responses

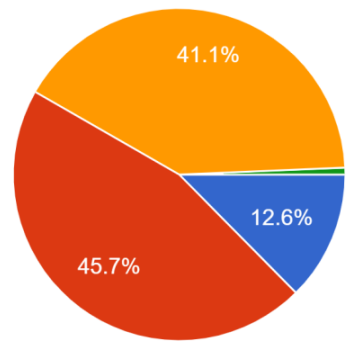

Многу ретко

Понекогаш

Многу често

Никогаш

Најголем број од граѓаните понекогаш или често подаруваат работи кои не им се потребни.

\section{Дијаграм бр.12}

Што најчесто поклонувате?

151 responses

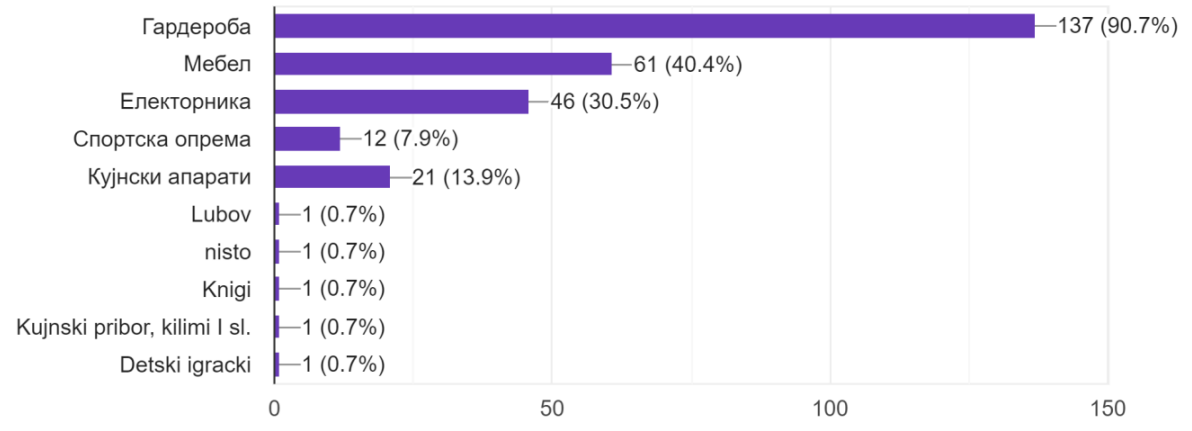

Најчесто се подарува гардероба и мебел, додека поретко спортска опрема, книги итн. 
Дијаграм бр.13

Со какви проблеми се справувате кога сакате да поклоните нешто? 150 responses

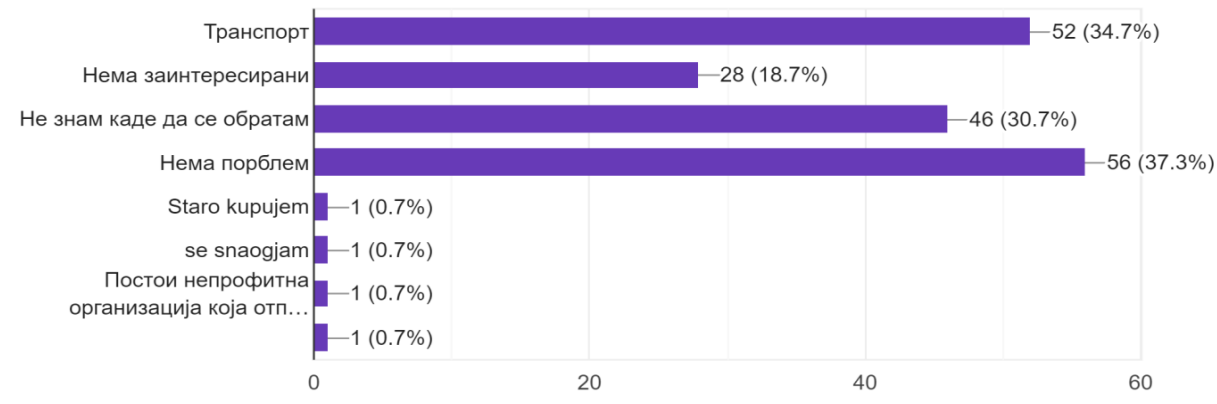

Од испитаниците 37,3\% тврдат дека немаат никаква потешкотија кога сакаат да подарат нешто, додека за 34,7\% транспортот е најголем проблем. 30,7\% не знаат каде точно да се обратат и како да постапат додека за 18,7\% било тешко да најдат заинтересирани. За 0,7 решение се неформалните собирачи, додека за други 0,7\% непрофитните организации.

Дијаграм бр.14

Во поглед на услуги за собирање/преземање на рециклабилен и опасен отпад, со кои од долунаведе...луги за собирање сте запознаени?

151 responses

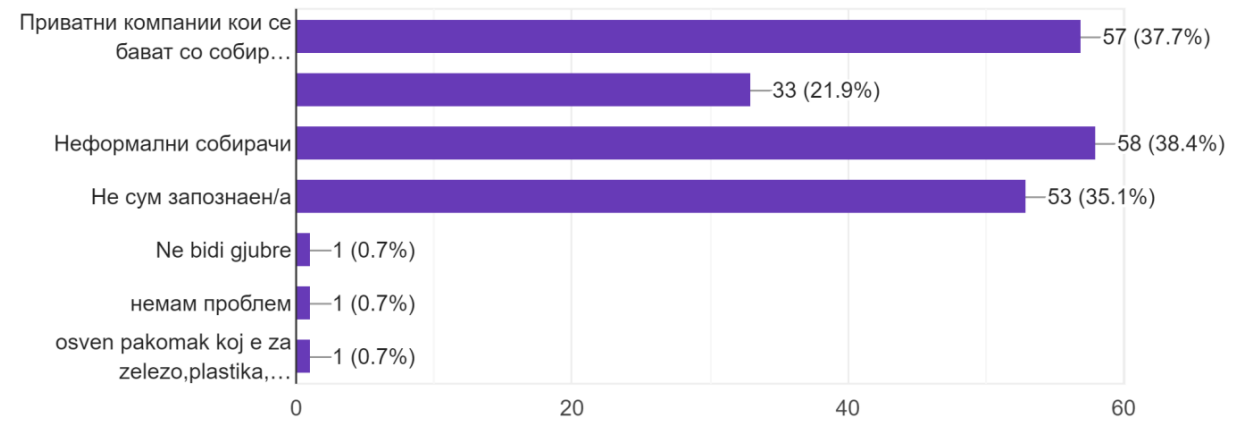

38,4\% испитаници се запознаени со можноста за преземање на рециклабилен или опасен отпад од страна на неформалните собирачи само 37,7\% имаат сознанија за тоа дека постојат компании и институции кои се занимаваат со таа дејност. $35,1 \%$ не се доволно информирани. 


\section{Дијаграм бр.15}

Во иднина дали би се решиле да контактирате некоја од приватните компании кои се занимваат со соби...орт, откуп на рециклабилен отпад? 150 responses

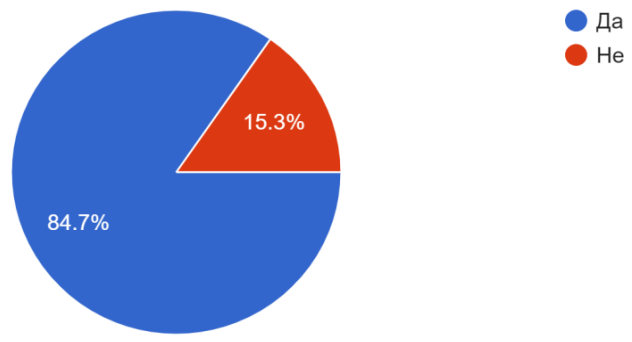

6,6\% од испитаниците имаат контактирано со институција/компанија или општина во врска со менаџирање на отпадот. Од нив 2,6\% тврдат дека имале одлично искуство, меѓу кои се спомнати и Нула Отпад. 1.9\% тврдат дека не добиле никаков одговор или требале премногу да чекаат за да дојдат да го соберат отпадот. Останатите посочуваат на проблемот дека ниту една компанија не прифаќа да соработува ако се работи за помала количина -според нивните стандарди.

\section{Дијаграм бр.16}

Кое е вашето ниво на информираност за тоа како да постапите со разни видови отпад и услугите кои се нудат од страна на институциите? 151 responses
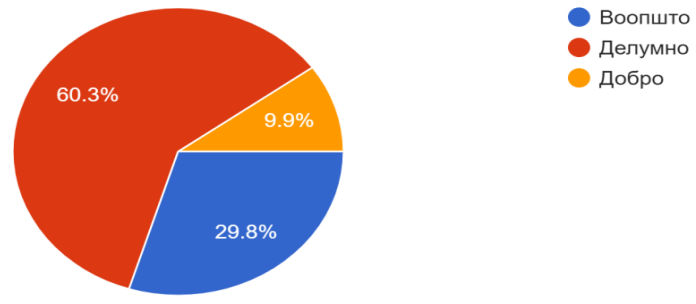

Само 9,9\% од испитаниците биле добро информирани како да постапат со различните видови отпад и услугите кои се нудат од страна на институциите, а $29.8 \%$ воопшто немале никакви информации. 
Кој според вас е најдобар начин за промовирање на ваков тип информации?

151 responses

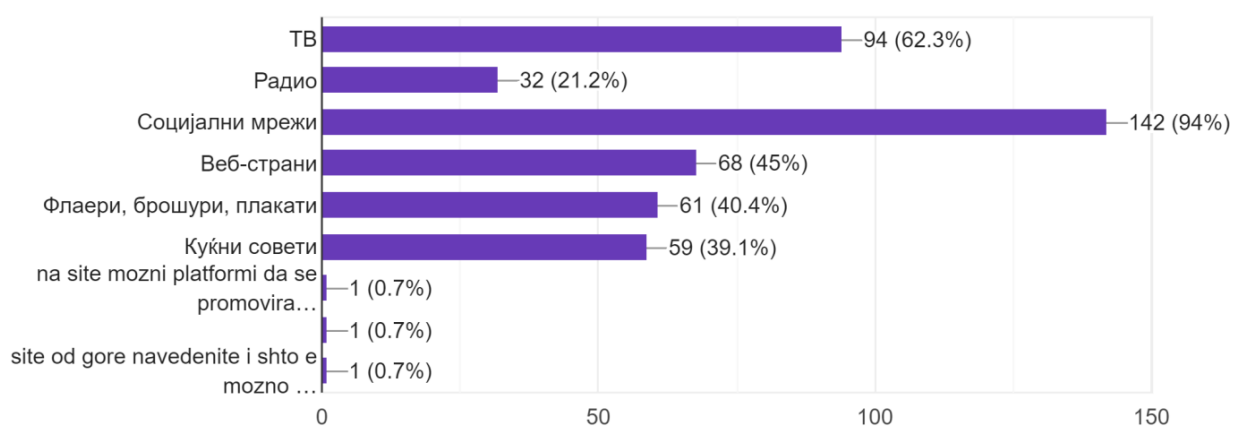

Водечкиот одговор со 94\% гласови е дека најдобар начин на промовирање на овој тип на информации за справување со отпад е директно преку социјалните мрежи. Промовирање на ТВ е следно со $62.3 \%$, додека веб страните се на трето место со $45 \%$ од гласовите. Промовирање преку куќните совети е поддржано од 39,1\%. Делење флаери, лепење плакати, печатење брошури е поддржано со $40.4 \%$ од испитаниците и покрај тоа што тоа би значело креирање на додатен отпад.

\section{Дијаграм бр.18}

Дали знаете што се случува со отпадот откако е собран од контејнерите?

151 responses

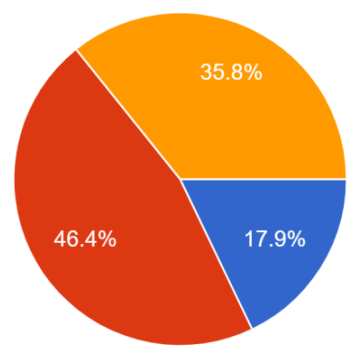

Да

Делумно

$\mathrm{He}$

35,8\% тврдат дека не се доволно информирани за тоа што се случува со отпадот откако е собран, додека $46,4 \%$ велат дека се делумно запознаени со процесот. 


\section{Дијаграм бр.19}

Според вас, дали со одпадот се менаџира правилно во нашата

држава?

151 responses
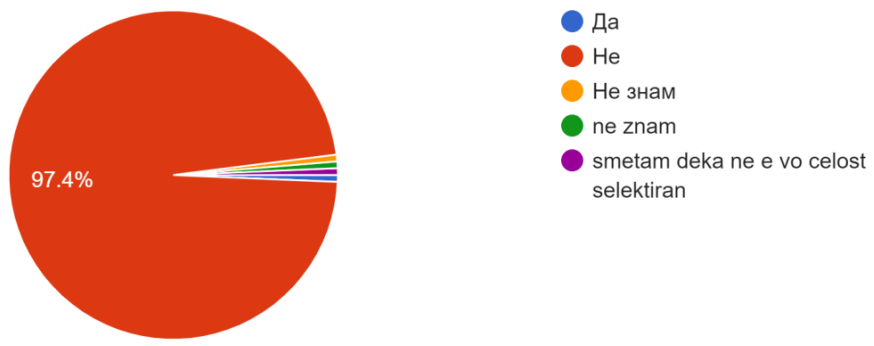

97.4\% испитаници тврдат дека во нашата држава не се менаџира правилно со отпадот.

Дијаграм бр.20

Дали сте свесни за штетите кои ги правиме на еко-системот поради современиот стил на живеење?

151 responses

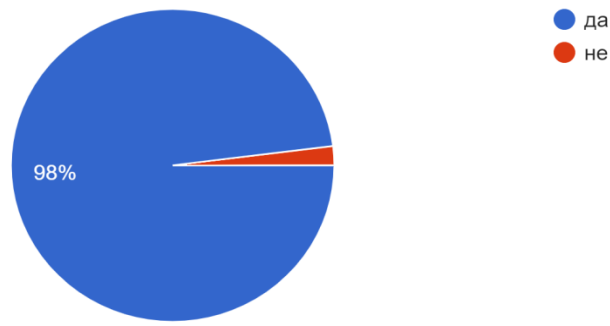

10.1 Во врска со ова прашање испитаниците беа замолени да напишат кратко за тоа што тие лично преземаат во врска со намалување на загадувањето на еко-системот. Одговор дале околу $60 \%$. Некои од нивните коментари се следните:

- Возам на плин и/или точак, се греам на струја и минимизирам користење на пластика.

- Се трудам да користам што помалку пластична амбалажа.

- Ретко користам пластични шишиња.

- Се обидувам да не возам кола многу често.

- Не користам пластика за една употреба. Користам sustainable продукти секогаш кога се достапни.

- Државата треба да преземе мерки и да не информира, ито можеме ние како граѓани да преземеме. 
- Cе трудам да бидам одговорен со селектирање на отпадот и да не го фрллам каде ито ќе стигнам.

- Ги фрллам отпадоците на места предвидени за тоа.

- Пробувам да сортирам отпад, итедам енергија, користам еко транспорт.

- Пробувам да користам производи од органско потекло колку можам повеќе.

- Користа торби за пазарење, избегнувам пластични/најлонски кеси.

- Избегнувам пластика за една употреба, кога пазарувам носам платнени торби, се трудам да купувам ресусни производи.

- Пробувам да го одвојувам отпадот со ито го правам рециклирањето поедноставно. Се трудам да ги следам сите светски трендови во врска со рециклирање и селектирање на отпад.

- Фрлам отпад прописно. Се приклучувам на акции за подигање на свеста во средината во која живеам.

- Го селектиран отпадот и внимавам на употребата на еко производи.

- Советувам луѓe.

- Рециклирам најмногу што можам, возам велосипед често.

- Се обидувам да итедам вода, да не користам производи кои содржат масло од палма , итедам електрична енергија, селектирам пластични шишиња, работам на еколошки проекти за зачувување на биодиверзитет на пасишта, се обидувам ито поретко да летам со авион, споделувам информации за практики коишто секој би можел индивидуално да ги спроведува за зачувување на средината.

- Зборувам и комуницирам со експерти.

- Свесно се грижам каде ги рециклирам и исррлам отпадните материи.

- Носам торба кога пазарам и редуцирам пластика дома.

- Купувам помалку производи, или производи без опаковка.

- Да правам помалку отпад, да не користам пластика.

- Строго почитувам правила каде и како одлагам отпад.

- Пробувам да минимализирам пластичен отпад, го складирам на страна со цел доколку нешто се промени соодветно да го отстранам. Старите батерии ги носам со себе и ги оставам во посебни корпи кои најчесто ги има на бензински пумпи, иако истите се полни скоро секогаш со обично ѓубре.

- Секогаш фррлам отпад во канта/контејнер, собирам отпадно масло за јадење и го носам во Суниленс.

- Практикувам поголема рационалност и скромност.

- Користам соларен систем на греење, купувам органска храна, користам платнени торби наместо пластичните ќеси, не ја загадувам околината со отпадоци (особено во природа или на патиштата.

- Cе трудам да најдам начин да се информирам дали има напредок во тој поглед од страна на институциите и давам предлози, секогаш водам сметка за мојот отпадколку што е тоа овозможено во мојата општина. Но сепак мислам дека немаме никаква еколошка свест во градот!

- Селектирам отпад и пробувам да влијаам на свеста на луѓето кои ме опкружуваат. 
- Намалена употреба на нерециклабилни материјали и користење на производи од екоматеријали.

Голем број од испитаниците имаат оставено додатни коментари искажувајќи ја нивната загриженост за моментална ситуација во градот Скопје. Многу од нив ја објаснуваа нивната разочараност од менталитетот на толпата и нивното некоректно однесување со отпадот. Дел ја искажуваат својата револтираност за тоа колку индивидуалците се немоќни и колку државата и институциите се игноранти кон оваа тема. Еден од коментарите посочуваше на тоа дека доколку се намали данокот за компаниите за рециклирање, автоматски ќе се зголеми профитабилноста, со што ќе се охрабрува увоз на отпад, а тоа би резултирало со поголема загаденост.

\subsection{5. Реализирана работилница со избрана фокусна група}

На 06.06.2019 во ОУ „Лазо Трповски“ се одржа работилница, средба со граѓаните од урбаната заедница Карпош 3, организирана од Општина Карпош, Институтот за комуникациски студии и претставници од Машинскиот факултет во Скопје. На повикот од општината се јавија триесетина жители од урбаната заедница Карпош 3.

Во текот на работилницата се разви дискусија во која граѓаните ги презентираа нивните искуства, ставови и идеи како да се подобри сегашната состојба на полето на справувањето со разни видови отпад. Нивните размислувања се однесуваа на следните клучни проблеми:

- Поддршка од институциите - Голем број од учесниците изјавија дека секојдневно вршат селекција на рециклабилниот отпад во нивните домови, но имаат проблеми со лошата организација за собирање на различните видови отпад, за што е неопходна поголема поддршка од институциите. Нема доволно поставени контејнери за сортирање на отпадот, означените контејнери немаат постојани локации, а често пати и се редуцира нивниот број. Уличните корпи за отпадоци кои се поставени низ регионот се честопати оштетени и нефункционални.

- Недостиг на мотивација - Според жителите, постојат повремени иницијативи и кампањи за почиста околина, но промените траат се додека не заврши проектот. За илустрација беше даден примерот со означените контејнери за стакло и иницијативата за собирање користено масло. На почеток од кампањите се врши фокусирање кон остварување на целта, но по извесно време промената престанува да функционира. При тоа, беше нагласено, дека промените можат да се случат посериозно доколку се применат мотивирачки стратегии или посериозно санкционирање.

- Недоволна информираност - Учесниците се пожалија дека не се доволно информирани за тоа како да постапат со повеќето категории на отпад, како на пример: шут од реновирање, стар мебел, стара облека, електроника, особено со остатоци од храна и друг органски отпад кој има најлошо влијание во однос на хигиената на контејнерите за собирање на отпадот од јавното комунално претпријатие. Граѓаните апелираа за подобро информирање и подобра промоција на телефонски броеви од компании/институции кои 
можат да помогнат или да го решат проблемот во такви ситуации. Исто така, беше нагласена потребата од информирање на начини достапни за сите возрасни групи, особено оние кои не користат социјални медиуми и интернет.

- Недоволна свест и едукација на граѓаните - Не сите се однесуваат совесно со отпадот и поставените контејнери. Беа дадени разни примери, како оштетување на уличните корпи од страна на граѓаните, несовесно фрлање на отпад во корпи кои не се наменети за таа категорија на отпад од страна на угостителски претпријатија итн. Исто така, беше посочен проблемот со затворањето на контејнерите, кое е тешко за манипулација и не е влезено во навиките на граѓаните. Поради тоа од нив се шири непријатна миризба и овозможува собирање на уличните животни. Свеста на граѓаните за тоа како треба да се постапува со отпадот и како да се чува околината е на многу ниско ниво.

Учесниците на работилницата преку бреинсторминг сесија дадоа предлози со можни аспекти за решавање на проблемот. На крајот од средбата тие изразија задоволство за покренатата иницијатива, со надеж дека барем некои од идеите ќе бидат прифатени од Општина Карпош и реализирани до крај. Исто така, беше испратена покана до организаторите ваква средба да се одржи и во урбаната заедница Влае.

- Соработка - од исклучителна важност за успехот на било која акција за подобрување на граѓанскиот однос кон отпадот е да се воспостават зрели и одржливи соработки со граѓанскиот и приватниот сектор, особено со здруженија и друштва чии дејности се сродни со општинските иницијативи. Граѓаните изразија огромна заинтересираност за нивно учество во создавањето и одржувањето на ваквите соработки.

\subsubsection{SWOT анализа на состојбата со отпадот во градот Скопје}

На крајот од првата фаза сите сознанија и впечатоци беа формулирани во заклучоци презентирани во вид на SWOT анализа, поточно анализа на предностите, слабостите, можностите и заканите во врска со состојбата со отпадот во градот Скопје. 


\section{SWOT Анализа на состојбата со собирањето на отпадот во градот Скопје}
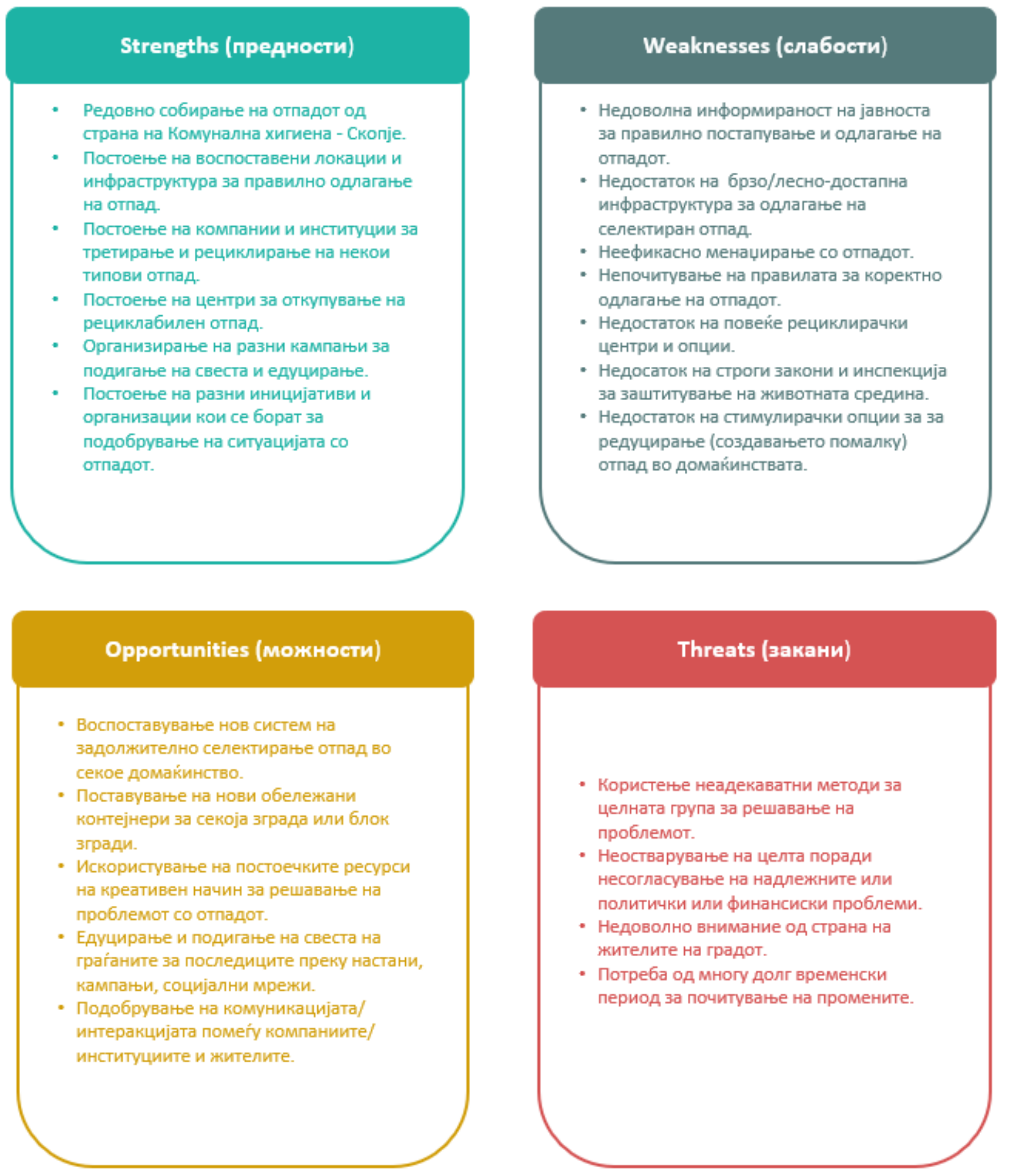


\subsection{7 Конкретна листа на барања од граѓаните}

На крајот од оваа фаза, како резултат на спроведената анкета и одржаната работилница предлозите и барањата на граѓаните беа анализирани и врз нивна основа беше составена листа од конкретни предлози до Институциите на власт во нашата држава:

- Санкционирање - да се дефинираат јасни правила на однесување со отпадот и нивното непочитување да е казниво со закон. Граѓаните да бидат добро информирани за истите, и нивното почитување да биде еднакво одговорно од страна на граѓаните и институциите. За жал, понекогаш казните можат да обезбедат поефикасни промени.

- Мотивација - да се најдат начини кои ќе ги мотивираат граѓаните не само да ја чуваат чистотата во нивната околина, но и да ја разубават. Беше предложено да се организираат натпревари помеѓу улиците или дворовите со прогласување на победник и медиумско ширење на информацијата. Дополнително, граѓаните треба да бидат мотивирани за поодговорен третман на јавните добра и да бидат агенти за воведување на промените охрабрени, а не напуштени, од институционалните механизми.

- Информации - подобро промовирање на информации поврзани со отпад како и телефонски броеви на институции/компании кои се надлежни и можат да помогнат. Покрај постирањето на социјалните мрежи, информациите треба да стигнат и до повозрасните жители. Еден од предлозите беше поставување табли со сите потребни информации во влезовите на зградите, поточно подобар пристап до такви информации за претседателите на куќните совети.

- Настани - да се организираат настани каде жителите можат да направат продажба, поклонување или размена на работи кои не им се повеќе потребни. Предложија покренување на повеќе иницијативи по примерот на проектот „Копче“ во рамките на Црвениот Крст. (https://www.facebook.com/pg/kopce/about/?ref=page internal) 


\section{2. Фаза 2 - дефинирање}

Во втората фаза е извршено попрецизно профилирање на таргет групата $и$ јасно дефинирање на општествениот проблем за кој треба да се бара решение - отпадот во урбаните средини во нашата земја. Во истата фаза е извршено истражување за обемот на проблемот преку извлекување на статистички податоци и како развиените земји се справуваат успешно со овој проблем.

\subsection{1 Профилирање на таргет групата}

По извршените опсервации, анкети и други анализи сликата за таргет групата, а во однос на навиките во врска со одлагањето на отпадот, можеше да биде јасно дефинирана и профилирана. Може слободно да се извлече заклучок дека нивните навики покажуваат дека граѓаните се:

- несовесни, неуредни и мрзливи, фрлаат отпад насекаде и не се грижат за заштита на околината;

- не се доволно едуцирани и информирани каде можат да го отстранат поспецифичниот отпад;

- немаат навики за селекција на отпадот заради рециклирање;

- не се доволно мотивирани за селекција на отпадот и за правилно отстранување на истиот;

- немаат страв од санкции затоа што се благи и Органите на Власта не ги спроведуваат строго;

- немаат навики за потегнување иницијативи за бенефит на општеството.

\subsubsection{Briefing - опис на задачата и воспоставување критериуми}

Врз основа на овие извлечени заклучоци целта на овој креативен процес станува сосема јасна: да се дефинираат мерки и средства со кои ќе се подобрат состојбите со отпадот во нашите градови, преку:

- промена на навиките на граѓаните за начинот на третирање на отпадоците;

- подигање на нивото на едуцираност (од најмали нозе) како да се постапува со различни видови отпад;

- подигање на нивото на информираност за значењето на намалувањето на количините на отпадот во животната околина, колку е тоа значајно за заедниците, за поединците, за идните генерации;

- подигање на мотивираноста за правилно постапување со отпадот;

- воведување на санкции за неправилно постапување со отпадот. 


\subsection{3. Факти во врска со количините на отпадот во светски рамки}

Еден од најголемите предизвици со кои светот се справува во последните години е менаџирањето со масовните количини на отпад кои се произведуваат секој ден, а достигнуваат до приближно 2.12 милијарди тони годишно во светски рамки.

Отпадот може да биде цврст, течен или гасен материјал кој се отстранува со рециклирање, палење или депонирање. Може да биде и помошен продукт во некој процес на производство или застарен комерцијален производ кој не може повеќе да се користи за својата намена. Тоа е резултат на нашиот секојдневен живот и не може да се избегне.

Според изворите на ВЕФОРУМ, Европа рециклира 30\% од својата пластика, додека Америка само 9\%, што посочува на тоа дека најголемиот дел од пластиките завршуваат во депонии и океани. Тоа лесно може да се заклучи преку доказите за големиот процент на пластика која може да се најде во рибите и останатите морски животни. Животните и природата не знаат како да се однесуваат кон вештачки создаден отпад, кој покрај тоа што ја загадува околината, често ги спречува нивните секојдневни активности, завршува и во животинскиот дигестивен систем и носи фатални последици. Не треба да заборавиме дека повеќето животни сочинуваат дел од исхраната на човекот, што доведува до заклучокот дека и човекот го консумира во некоја доза отпадот кој самиот го создава.

Од 1950-тите години, човештвото има создадено 9.1 милијарди тони пластика од кои 79\% се сеуште во депонии или во природата. Само $12 \%$ се согорени, додека само $9 \%$ се рециклирани. Половина од произведената пластика во последните 70 години е направена во последните 13 години. Според калкулациите се смета дека за 30 години на планетата ќе бидат создадени 50 милијарди тони пластика.

Во денешно време САД се на прво место како држава која произведува $40 \%$ од отпадот на целиот свет. Отпадот од развиените земји се решава така што константно се извезува во помалите неразвиени држави.

Експлозијата на пренаселеност, брзата урбанизација и индустријализација има создадено дисбаланс во екосистемот. Голема популација треба да е задоволена со добра инфраструктура, санитарни услови, транспорт, сместување и други услуги кои создаваат зголемување отпадна вода, отпад од домаќинствата, индустриски отпад итн.[13].

За отстранување на отпадот, сепак на крај излезот се гледа во самата природа. Закопување на отпадот во земјата е главното решение кое се практикува најчесто низ светот. Во овој процес на отстранување спаѓa и согорувањето, кое се прави со цел да се намали волуменот, а притоа поради различна реакција на материјалите при разни температури се испуштаат и токсични супстанции кои го загадуваат воздухот $и$ предизвикуваат токсични дождови. Истите тие материи кои завршуваат во земјата, ја загадуваат почвата што резултира со канцерогени плодови, загадени подземни води и слично [46]. 


\subsection{4. Отпадот и природата}

„Не можеме да продолжиме со бизнисот како до сега, освен ако не сакаме цела планета буквално да биде покриена со пластика.“ вели Roland Geyer - Industrial Ecologist, UC Santa Barbara. Тој исто така посочува дека иако можеби сме креирале машини кои ја собираат пластиката од водите, тоа не го спречува фрлањето на нов отпад во океаните [45].

He ce' што се произведува може да се рециклира, што значи дека единствено решение е драстично редуцирање или прекинување на производството, тука особено се мисли на пластиката [45].

Отпадот со органско потекло како дрва, растенија, плодови, храна и др., сами се разградуваат со тек на време, но додека и оваа категорија не е соодветно контролирана, може да се шират разни болести, лоши миризби, нечистотии и слично. Другите типови на отпад, особено тој со опасен / токсичен состав преставуваат проблем во голема мера, но пластиката е најмногу дискутирана во последно време поради количините во кои се произведува, хемиските карактеристики и лошиот начин на отстранување.

Последиците кои се резултат на неконтролирано и несовесно менаџирање со отпадот се следните:

1. Загадена почва - многу од отпадните материи кои завршуваат во депонии или во природата испуштаат хемикалии кои ги впива земјата.

2. Загаден воздух - отпад од испарување и испуштање опасни хемикалии, миризби итн., доведува до климатски промени.

3. Загадена вода - најчесто хемикалиите од почвата завршуваат во подземните води кои се неопходни за живот.

4. Лошо влијание врз здравјето на човекот - дивите депонии, неправилно отстранување на отпадот и разните процеси за третирање на опасен отпад се извор на болести.

5. Лошо влијание врз живите суштества и морињата - отпадот најчесто содржи вештачки материи и карактеристики кои животните и природата не можат да ги препознаат и не знаат како да се справат со нив.

6. Креирање извор на болести кои лесно се шират преку комарци, стаорци, мувла итн..

7. Пропуштени шанси за рециклирање, реутпореба веќе постоечките материјали.

8. Предизвикување на климатски промени

9. Тивко и бавно убивање на планетата.

\subsection{5. Менаџирање со отпадот}

Менаџирањето на отпад започнува со генерирање на истиот, минимизирање, транспорт и отстранување [44]. Елементи важни за процесот се:

- Планирано менаџирање - отпадот треба да биде карактеризиран според состав, извор, вид. Овој тип на статистика помага во создавање можности за намалување на загаденоста, реупотреба, рециклирање. 
- Превенција на создавање отпад - преку дизајнирање и користење процеси со кои се превентира или минимизира количината на создавање отпад.

- Рециклирање и реупотреба - значајно помага во намалувањето на создавањето отпад. Со имплементирање на рециклирањето на материјалите им се продолжува животниот век, слично се случува и со реупотребата.

- Третман и отстранување - остатокот од отпадоците кои не можат да бидат редуцирани, превентирани, реупотретебувани, рециклирани или обновени треба да се третираат и отстранат на начини кои не би имале влијание врз човекот и околината. Тоа најчесто значи разни биолошки, хемиски и физички третмани кои не се токсични.

- Складирање на опасен отпад - секогаш мора да биде контролиран, никогаш да не дојде во контакт со воздух, земја или вода. Поради тоа се складираат во затворени контејнери, кои не овозможуваат директен контакт со сонце, дожд, ветер итн.

- Транспортирање опасен отпад - за вакви случаи треба да се следи строг протокол, за да се минимизираат опасностите од незгода.

- Третман и отстранување на опасен отпад - во случај да не постојат комерцијални или објекти поседувани од владата, каде се собира ваквиот тип на отпад, тогаш самите производители треба да се сертифицирани и способни да го третираат и отстранат истиот.

- Мали количини на опасен отпад - токсични материјали се неизбежни и се создаваат секојдневно и при банални работи, одржување во домаќинствата, градежништвото итн.

Во земјите каде не се селектираат употребливите состојки во местото на создавање, мешаниот отпад се носи во специјални центри. Тој понатаму се селектира, делумно со човечка помош, делумно со примена на големи машини наменети за одделување на метал, пластика, алуминиум, стакло (употребливи материјали). По процесот на селектирање отпадот се транспортира во рециклирачките центри или депонии.

\subsection{6. Намалување на загадувањето на животната околина преку рециклирање на отпадот}

Некои видови отпад имаат својства кои им овозможуваат да се обработуваат и пак да бидат употребувани и трансформирани во нови производи. Овој процес се нарекува рециклирање и ветува многу за заштитување на животната средина.

Но што всушност може да се рециклира и колку пати? Амбалажи на грицки, чоколади, овошја, зеленчуци итн. кои се светкави, обоени, содржат фолија и не се рециклабилни. Таков е случајот и со стиропор, најлонски кеси, пакување од брза храна, замрсени кутии или хартија, пластичен прибор за јадење, тоалетна хартија, салфетки, целофан, огледало, медицински игли, тањири, дрва финиширани со разни хемикалии, кабли, нечисто стакло и многу други, не можат да бидат обработувани и да им се продолжи животниот век.

Од друга страна чисти пластични шишиња, капаци, чист картон, хартија, конзерви, алуминиум, челик, метали, стакло можат да бидат рециклирани. Но, сепак, треба да се има на ум 
дека некои материјали не можат бесконечно пати да бидат рециклирани. Во табелата 2. се претставени некои најчесто употребувани материјали и колку пати можат да се рециклираат [46].

Табела 2.

Колку пати можат да се рециклираат материјалите

\begin{tabular}{|c|c|c|}
\hline Пластика & $\begin{array}{l}\text { 1-9 пати } \\
\text { *во зависност од типот }\end{array}$ & $\begin{array}{l}\text { Во зависност од типот, после назначениот број пати на } \\
\text { рециклирање пластиката завршува во текстилната } \\
\text { индустрија }\end{array}$ \\
\hline Алуминиум & бесконечно & $\begin{array}{l}\text { Може да се рециклира бесконечен број пати поради што се } \\
\text { смета за многу вреден материјал. }\end{array}$ \\
\hline Метал & бесконечно & Може да се рециклираат бесконечен број пати \\
\hline Хартија & 5-7 пати & Со секое рециклирање се намалува животниот век \\
\hline Стакло & бесконечно & $\begin{array}{l}\text { Поисплатливо е да се рециклира стакло бесконечен број } \\
\text { пати отколку да се произведе на ново. Но, важно е да се } \\
\text { запази типот на стакло бидејќи сите имаат различна точка } \\
\text { на топење. }\end{array}$ \\
\hline
\end{tabular}

Рециклирањето понекогаш не е едноставно бидејќи треба да се следат неколку правила за да може да се реализира. Многу важно правило е дека рециклабилните амбалажи треба да бидат чисти, измиени пред нивно одлагање.

Строго се препорачува хартијата да не се сецка бидејќи така се скратуваат целулозните влакна, додека стаклото, ако е скршено не може понатаму да се обработува и мора да биде строго двоено според бојата.

Најважно е се' да биде селектирано според видот, бојата или својствата. Информации за тоа како правилно треба да се делат различните видови рециклабилни отпадни материи може да се најдат на интернет или кај локалните надлежни институции.

При рециклирање на 1 килограм алуминиум се заштедуваат 14 киловати енергија односно 90-95\% од потребната енергија за да се произведе истата количина од бокситна руда. Исто така се заштедуваат 4.8 тони нафта која се користи при екстракцијата и производство на сиров алуминиум. Алуминиумските лименки може да се рециклираат во целост неограничен број пати. Земјите како Швајцарија, Германија, Финска, Норвешка, рециклираат над 90\% од алуминиумските лименки.

Процесот на рециклирање пластика е далеку поисплатлив отколку добивање на пластика од суровини. Со 1 тон рециклирана пластика се заштедуваат околу 2 тони нафта и 5700 киловати енергија. Со рециклирање пластика значајно се заштитува животната средина и се намалува ефектот на стаклена градина. 


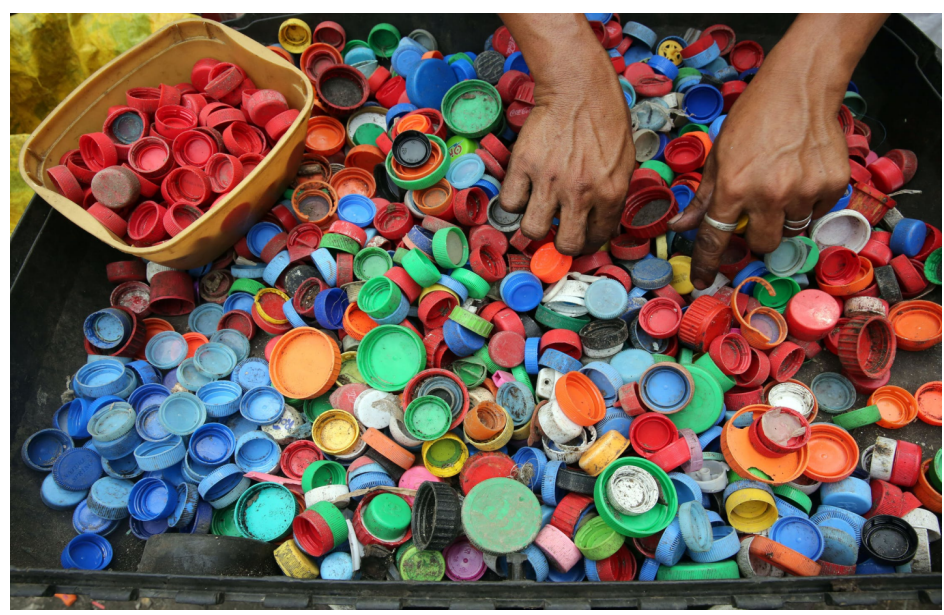

Сл. 27. Селектирање на капачиња

\subsection{7. Менаџирање и рециклирање на отпадот како бизнис}

Рециклирањето не е само "спасување“ на материјалите кои ја поседуваат таа карактеристика, тоа е целосен економски систем. Во периоди кога има голема побарувачка на рециклабилни материјали, сите се „победници“. Наспроти тоа, ако дури и само за еден производ побарувачката е ниска, а за другите е на задоволително ниво, претставува закана на рециклирачкиот пазар. Како и да е, позитивна страна на ваква ситуација би била дека и покрај тоа што добивката од производ е ниска или непостоечка, се избегнуваат трошоците за праќање во депонија.

Во денешно време просечната цена за рециклирање на картон, хартија, алуминиум и пластика е над вредноста на трошоците за процесирање, што значи дека е профитабилно. Од друга страна рециклираното стакло скоро секогаш претставува загуба за рециклирачките компании поради тоа што многу тешко или скоро никогаш нема побарувачка на пазарот [35].

Проблемите во рециклирачкиот пазар се многу обемни, а поради тоа што не е политички коректно, често се чува во тајност всушност колкава количина од материјалите завршуваат во депонија. Пластиката претставува најголем проблем, поради тоа што само неколку видови на пластика се рециклабилни (РЕТ најпогодна), а за да се олесни работата на рециклирачките центри, треба да се постават контејнери за сортирање за сите 7 постоечки видови на пластика [36].

Двоењето на видовите пластика во центрите е многу тежок процес бидејќи треба да се прави рачно. Пред извесно време имало иницијатива за градење на лента со разни степени на топлина (секој вид пластика има различна точка на топење) со цел типот на пластика да се стопи и залепи на лентата. Трошоците за оваа иновација се огромни и едноставно непрофитабилни за компаниите [55].

Друг проблем е тоа што пластиките/амбалажите скоро никогаш не се чисти и спремни за рециклирање, што е еден од главните причини поради кои Кина има забрането увоз на повеќе пластики. 


\subsection{8. Примери како се врши справување со отпадот во светот}

Интересен факт е дека до неодамна Кина се сметаше за земја која најмногу придонесува за светското загадување, воедно и дека произведува најмногу отпад. Реалноста е дека Кина до 2018 година увезуваше најмногу отпад, што значи дека била земја која се справувала со најмногу отпад глобално. Од 2018 година државата донесе решение да забрани увезување на многу видови отпад, што направи големите сили, како Америка на пример, да се запрашаат за своите постапки. Сега повеќето големи држави се принудени сами да го регулираат и третираат отпадот.

Германија е водечка земја во рециклирање на отпадот. Веднаш по Германија се Австрија и Јужна Кореја, блиску се и Велс, Швајцарија и Словенија. Споменатите се во можност да рециклираат од $52 \%$ до 56 \% од нивниот отпад.

Според Еуномиа, во државите кои се успешни во ова, постојат закони кои охрабруваат или задолжуваат рециклирање, со што им се олеснува на домаќинствата да рециклираат и да го селектираат отпадот. Покрај добрите финансиски инвестиции, исто така, тие поставуваат јасни цели и закони за локалните власти [56].

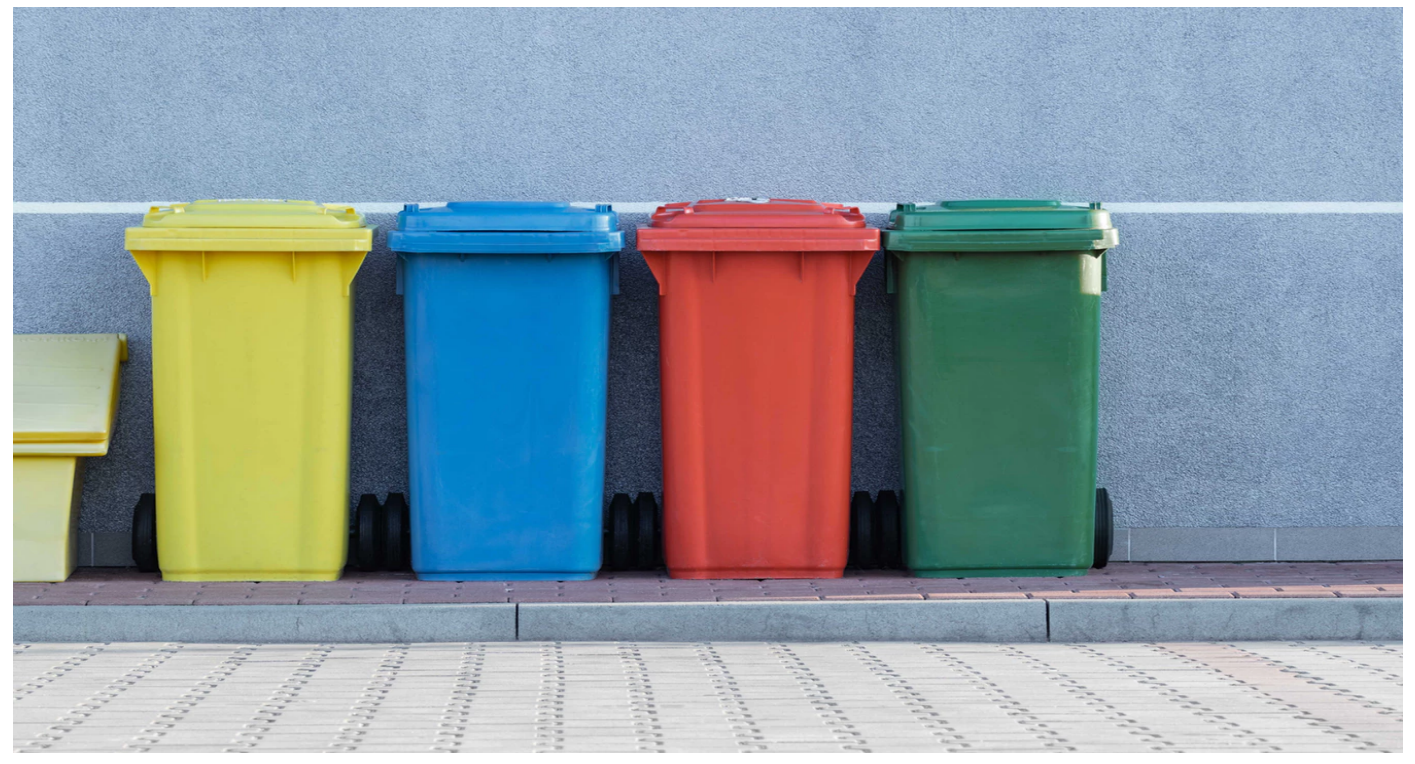

Сл. 28. Пример на сортирање на отпад од домаќинствата.

Во Германија постојат екстремно строги правила за примарно сортирање на отпад во домаќинствата. Назначено е точно кој вид на отпад во кој контејнер се одлага, и кој ден во неделата ќе биде собран од надлежните (сл. 28). На пример:

- Со жолта боја се назначени контејнерите во кои се одлагаат амбалажи, лесни пакувања како тетрапак, пластични кеси, алуминиумски фолии, пластични шишиња итн.

- Со зелена или сина боја се означени контејнерите во кои се одлагаат хартијата и картоните. 
- Ц Црни или сиви се контејнерите во кои се одлага остатокот од отпадоци од домаќинствата кои не можат да бидат рециклирани и не спаѓаат во ниедна друга категорија од означените контејнери.

- Био отпад или кафени контејнери (некогаш зелени) се наменети за компост, природен отпад од храна и разни природни материи [56].

Кога се работи за несекојдневен отпад, или поретка категорија, постои распоред за тоа кој ден од месецот може истиот да биде оставен на улица и собран од надлежните.

Користењето "second hand" предмети се практикува многу. Ce' што не им е повеќе потребно на поединците или домаќинствата го донираат или продаваат во назначените места, од каде други можат да ги купат или преземат.

Уште во осумдесеттите беше тренд на подарување на работи кои не се корисни на една личност на друга, добар пример е тоа дека кога некој во соседството има новороденче, сите соседи ги донираат своите предмети наменети за бебиња кои не ги користат повеќе.

Друг многу важен начин на справување со отпадот е поставување на така наречени „Reverse Vending Machines“ или автомати за рециклирање. Тие најчесто се поставени во супермаркети и примаат стаклени шишиња, пластични шишиња или лименки, а за возврат се добиваат од 8 до 25 центи по парче. Во некои маркети добиената сума се користи како ваучер во истиот супермаркет. Вакви автоматизирани машини има во сите поразвиени европски земји како Холандија, Скандинавските земји, Швајцарија итн., но и пошироко низ светот. Во Јужна Америка со ваков тип на машини наместо паричен надомест се доделуваат купони, попусти или ваучери за разни настани. Во други држави за возврат за дадениот рециклабилен материјал во автоматите поставени на улиците се обезбедува храна за уличните животни.

Во Шведска првиот концепт за собирање на лименки постои од 1984, додека за пластични шишиња од 1994, со што се овозможува рециклирање на 1.8 милијарди шишиња. Во Скандинавските држави важат истите строги правила за примарна селекција на отпадот. Најчесто зградите или поголем број на домаќинства имаат заеднички контејнери за кои подеднакво ја носат одговорноста. Шведска е исто така позната по тоа дека ги има надминато своите поставени цели за рециклирање. Таков е примерот со поставена цел за рециклирање на $70 \%$ од стаклото, а тие имаат постигнато рециклирање на $93 \%$.

Шведската економија има за цел да се потпира во иднина на концептот на Циркуларната економија, која претставува реупотреба на сите материјали и производи со цел сведување на производството-од-нула на што пониско ниво, поточно главна карактеристика да им биде реупотреба. Друга цел на Шведската влада е да го редизајнираат начинот на живот и однесување на луѓето, со цел да овозможат на консуматорите да делат и реупотребуваат секакви видови на алати, облека, мебел, работни места и домови. Во 2017 година Шведска ги реформираше своите даноци за да помогне $и$ стимулира еколошко однесување на народот како $и$ институциите/компаниите. Поправките на веќе користени предмети се многу поевтини, а даноците на компаниите за рециклирање се минимални или непостоечки. Друг пример е модниот бренд X и М кој им нуди попуст на сите купувачи кои донираат стара облека [57] . 
Во Холандија како и во другите европски држави некоректно сепарирање на отпадот е казниво со закон. Во оваа земја е актуелно движењето познато како „Скапоцена Пластика“, кое поради иновативноста е веќе глобално познато и применувано."Precious Plastic" е составена од мала група на луѓе кои имаат откриено начин како со многу помал буџет да се креираат 4 машини за рециклирање на пластика и произведување на мали предмети од истата. На нивата веб страна нудат детални инженерски цртежи и видеа со објаснување како да се изградат тие машини [58].

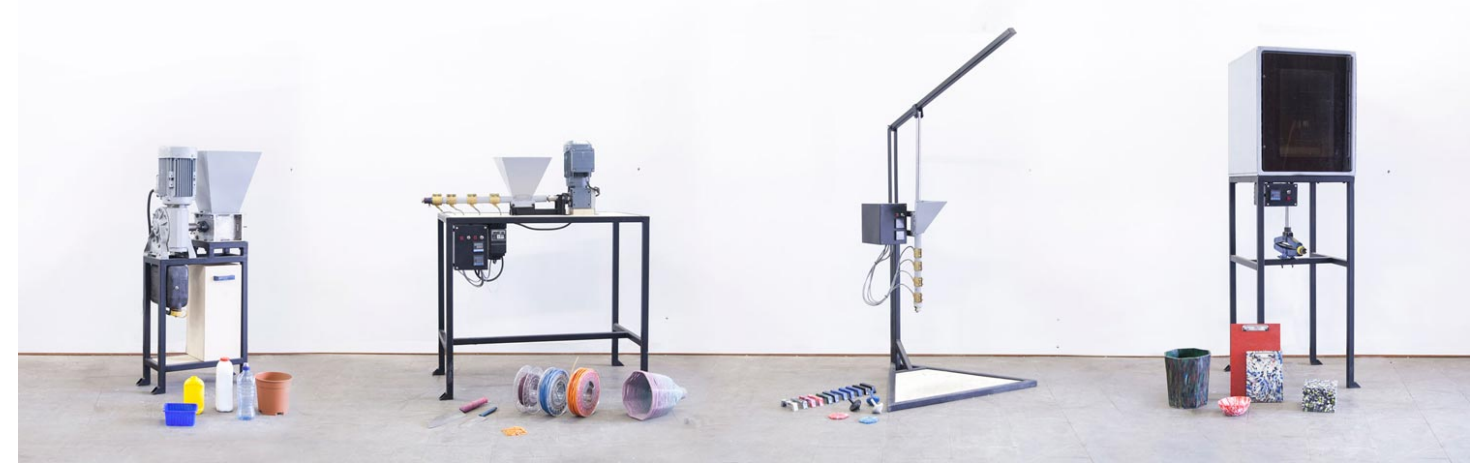

Сл. 29. Машини креирани од Скапоцена Пластика

извор : preciousplastic.com

Во последно време САД се соочуваат со голем проблем за справување со целиот отпад кој се создава секојдневно. Преку разни кампањи, предавања во школи, работилници, разни организации пробуваат да ја подигнат свеста на $2 / 3$ од населението кои се игнорантни кон целата ситуација. Една од тие организации е Кип Америка Бјутифул (“Кеep America Beautiful”) која се бори за ставање крај на отпадот. Преку организирање разни настани се трудат да ги мотивираат граѓаните да консумираат паметно и да го сортираат отпадот. Со една од нивите кампањи советуваат и организираат посети на депониите, за да можат луѓето да имаат јасна слика за тоа што точно се случува таму [59]. Исто така се трудат што повеќе да го олеснат целиот процес на сортирање и рециклирање за да не претставува никаква потешкотија на поединците, поточно лесно да се вклопи во секојдневието на индивидуалците. Во САД 15-ти Ноември е прогласен како ден на рециклирање. "Garage Sales“ се приватни неформални организирани продажби каде индивидуалците продаваат или поклонуваат работи кои нив не им се повеќе потребни. Најчесто се организираат во приватни дворови, на улица, во парк, посебно се популарни помеѓу студенти кои се селат.

Во Индија често родителите наместо да ги праќаат своите деца во школо одлучуваат да ги вработат. Понекогаш причина за тоа е и висината на школарината која треба да се плаќа. Mazin 
Muktar and Parmita Sarma се учители кои водат мало училиште. Откако станале свесни за мизерната ситуација со отпадот во нивната околина, одлучиле студентите да ја плаќаaт школарината со пластични шишиња. Шишињата кои ги добиваат ги реупотребуваат со нивна пренамена или ги продаваат во депонии за да заработат доволно за да може да опстои школото. Ова е многу добар пример за тоа како се прави општествено влијание преку решавање на два проблеми одеднаш [60].

Бидејќи Сингапур е мала држава по површина, имаат откриено ефикасен начин како да го отстранат отпадот. Иако тоа најчесто завршува во согорните центри, енергијата која се генерира од истите потоа се користи за снабдување на домовите. Од целиот процес сите токсични материи кои се ослободуваат се прочистуваат, а тоа што останува е пепел кој завршува во вештачки базени.

Во Индонезија за да ги мотивираат граѓаните да рециклираат, автобуските карти во јавниот превоз се наплаќаат со пластични шишиња [61].

Словенија започнала со сортирање на отпадот во означени контејнери во 2002 година. Од тогаш до денес депониите веќе добиваат 80\% помалку отпад. Сортирањето, рециклирањето и реупотребата се веќе станати дел од нивната култура и секојдневие. Во главниот град Љубљана постојат два отворени рециклирачки центри кои се многу популарни и имаат голема посетеност во текот на денот. Во план е да изградат уште такви низ целата држава. Во Словенија исто така организираат неделни работилници каде ги учат луѓето како да вршат поправки на разни предмети за домаќинствата [62].

Во Кенија е целосно забранета употребата на пластични кеси. Се казнува со 4 години затвор или 40000 \$ за произведување, продавање или носење пластична кеса. Канада и земјите членки на Европска Унија веќе работат на тоа и имаат донесено соодветни закони, а се планира да стапи во сила забрана за користење на пластика за едно употреба од 2021 година.

Во Камерун реките се целосно покриени со пластичен отпад, најмногу шишиња. Поради тоа што е сиромашна држава, власта не ја разбира како приоритет грижата за животната средина. Иницијативата Madiba and Nature составена од триесетина волонтери го има преземено во свои раце чистењето на реките. Од собраните шишиња тие прават чамци за рибари. Досега имаат собрано и искористено околу 25000 шишиња [63].

Во Солун еден архитект и дизајнер имал идеја да ја собира пластиката која може да се рециклира и од истата да креира клупи низа парковите во градот преку 3D принтање. Уникатно е тоа дека тој често ги вклучува и жителите на градот во дизајнирањето на клупите. Тие моментално се во голем тренд поради формите и удобноста. Издржливи се на било какви временски услови поради карактеристиките на пластиката како материјал [64].

Од 2019 година класифицирањето на отпад е задолжително во Шангај. За да се олесни максимално практикувањето на новите правила, тие имаат поставено „паметни“ контејнери, кои се способни да детектираат и алармираат доколку погрешен вид на отпад се фрли во погрешен контејнер. Камионите за собирање на контејнерите се во можност да ги идентификуваат според видот и да ги празнат само тие кај кои е потребно [65]. 


\subsection{9. Социјални движења}

Движење „Нула отпад“ е многу популарно и модерно движење, но многу малку луѓе глобално се во можност да се приклучат. Постои подолго време, но стана јавно популарно во почетокот на 2000-тите години. Во денешно време со помош на социјалните мрежи добива прилично голема поддршка, но сепак не е многу успешна во „регрутирање“ нови членови. Ова движење се бори за целосно елиминирање на отпадот, штедење енергија и вода, преку разни начини. Имаат воспоставено неколку правила според кои се водат, а тие се:

1. Одбивање - неприфаќање на работи кои не ни' се потребни, како поклони, реклами, бесплатни предмети. На работите да се гледа како 'junk mail' кој не ни е потребен.

2. Редуцирање - разгледување низ предметите во домот и идентификување на работите кои не ни се потребни или работи кои се дупликати кои општеството не убедува дека ни требаат. Донирање на истите.

3. Реупотреба - користење на реупотребливи работи, како платнени торби или стаклени тегли за пазарење итн.

4. Рециклирање - работи кои едноставно се неизбежни во секојдневието, но мора да се рециклираат на крај.

5. Компостирање - органски отпад се најчесто остатоци од храна или градинарење кои се разградуваат и стануваат хранливи за почвата.

6. Направи сам - многу важни производи доаѓаат во пакувања, кои едноставно се неопходни и дел од секојдневието, како дезодоранс, паста за заби итн. Се советува истите тие да се направат дома од природни состојки, што покрај тоа што елиминираат отпадоци, се исто така многу поздрави за човекот.

\subsubsection{0. Социјални мрежи}

Моќта на социјалните мрежи во модерниот свет е недискутабилна. Преку нив се пристапува до таргетирани групи, незабележливо се наведува начин на размислување, начин на живот итн.

Пред извесно време на социјалните мрежи се појави предизвик \#trashgtag, кој повикуваше на ставање слики на локации со отпад и потоа слики од истите откако биле исчистени со самоиницијатива на објавувачот на истите. За само неколку дена предизвикот стана вирален, популарен низ целиот свет, но после неколку недели исчезна како и сите други трендови во светот на интернетот. Сепак беше еден од поефикасните предизвици за глобалното добро и остави зад себе добар траг [66]. Постирање слики од диви депонии низ градот и тагнување на општините исто така беше тренд во повеќе држави, а беше применет и во нашата земја.

Recycling Bank е интернет страна која нуди едукација за тоа што е рециклирање и како се прави. Имаат објавено дека поединци се зачленуваат за да добијат награда, додека други се зачленуваат бидејќи го живеат тој начин на живот. Членови кои рециклираат се наградувани со поени кои може да ги користат во разни прилики и места (www.recyclebank.com). 


\subsubsection{1. Состојбата со отпадот во Македонија}

Во Македонија еколошките проблеми се типични за регионот, концентрирани се на загаденоста на воздухот и водата, особено во главниот град Скопје како и шумите кои се во исчезнување. Се смета дека најголемите загадувачи се домаќинствата и индустриските канализациони системи, додека во земјоделските подрачја претежно главните загадувачи се фармите и индустријата за преработка на храна, особено млечната и месната. Водите не се филтрирани ниту третирани, поради што цинк, олово и кадмиум се пронајдени во реката Вардар, а слично е и со останатите реки. Најголемите загадувачи на водата се хемиската и металуршката индустрија, производството на кожа, храна.

Отпадот може да биде класифициран во разни категории, на пример според агрегатната состојбата (цврст, течен или гасен). Цврстиот отпад потоа се дели на био-деградивен или не. Може да се класифицира и според составот или пак според тоа дали е комунален или не. Категоризирањето на отпадот е посебно важно за полесно справување, планирање $и$ отстранување на истиот. Според Агенцијата за заштита на средината како и Министерството за животна средина и просторно планирање на Македонија постојат главна и споредна класификација. Според главната класификација постојат следните категории отпад[50] :

1. Опасен отпад кој содржи опасни супстанции со својства од типот на реактивност, запаливост, експлозивност, инфективност, канцерогеност, мутагеност, раздразливост, токсичност, испуштање отровни гасови при контакт со вода, воздух или киселина.

2. Неопасен отпад што не ги поседува карактеристиките споменати во претходната категорија.

3. Комунален отпад за кој се одговорни општините: отпадот од домаќинствата, масовен отпад од комерцијални и трговски дејности, институции и мали бизниси, уличен смет, содржината од контејнерите од службени згради, отпад од дворовите и градините.

4. Комерцијален отпад кој се создава од правни и физички лица при вршење индустриски, комерцијални, услужни, административни, занаетчиски дејности. Најчесто е сличен на отпадот од домаќинствата.

5. Отпад од индустријата кој се создава од преработувачката индустрија и деловни субјекти.

Во Македонија најголемото количество на собран комунален отпад (99.5 \%) се исфрла во депониите. Во табела .3 се презентирани податоци преземени од Државниот Завод за статистика на РСМ за 2018 кои покажуваат дека 81\% од отпадот потекнува од домаќинствата. 
Табела 3.

Количество отпад во Република Северна Македонија во 2018 година

\begin{tabular}{|l|l|}
\hline Република Северна Македонија & 854865 тони \\
\hline Скопски регион & 166029 тони или 26,5\% \\
\hline По жител & 412 кг \\
\hline Од домаќинства & 109002 или $81 \%$ \\
\hline Комерцијален отпад & $19 \%$ од вкупното \\
\hline
\end{tabular}

Годишното количество на создаден комунален отпад по жител е за 8.6 \% повеќе од 2017 година, додека за околу 60 кг по жител повеќе од 2008 година. Вкупното количество собран отпад се зголемил за околу 141300 тони во текот на претходните 10 години, што е само потврда за тоа какво влијание има развојот на модерниот свет.[50]

Табела 4.

Количество собран комунален отпад за 2018

\begin{tabular}{|c|c}
\hline Хартија & 7729 T \\
\hline Стакло & 2288 т \\
\hline Пластика & 8532 т \\
\hline Метал & 1991 T \\
\hline Органски & 35756 т \\
\hline Текстил & 7837 T \\
\hline Гума & 673 т \\
\hline Измешан комунален отпад & 535604 т \\
\hline Останато & 24975 т \\
\hline
\end{tabular}

Во руралните средини нема организирани системи за собирање на отпад, што значи дека отпадот завршува во диви депонии или селско буниште. Таков отпад се смета за генериран, но не и собран. [34].

Во менаџирање со отпадот спаѓаат собирање, селектирање, транспортирање, третман, преработка, складирање и отстранување на отпадот. Дел од отпадот се преработува со цел да се искористат употребливите материи и состојки, или реупотреба заради искористување како извор на енергија или рециклирање. Целосното отстранување најчесто се прави со горење, а некои од опасните материи се уништуваат со посебен третман преку разни процеси. Постојат и други решенија за отпад кој не може да биде реупотребен или преработуван. 
Околу 99\% од отпадот секако завршува во депониите - објекти наменети за истурање на отпад под или над земја. Некои видови на отпад се извезуваат надвор од државата.

Селектирање на употребливи отпадни материи во местото каде што се создаваат не е дел од нашата култура/систем или пак е екстремна реткост .

\subsubsection{2. Законски регулативи во врска со отпадот во Македонија}

Во Република Македонија постојат повеќе закони кои покриваат и решаваат одредени проблематики и прашања поврзани со отпадот. Дел од тие закони кои се во надлежност на Министерството за животна средина и просторно планирање се следните:

- Законот за животна средина

- Закон за управување со отпад

- Просторен план на Република Македонија (Службен весник на Р.М. бр. 39/04)

- Базелската Конвенција во врска со контролата врз прекуграничните загадувања со опасен отпад и негово депонирање/Basel Convention on the Control of Transboundary movements of Hazardous wastes and Their Disposal. Конвенцијата е ратификувана со Закон за ратификација објавен во (Службен весник на Р.М. 49/97)

- Амандман на Базелската Конвенција во врска со контролата врз прекуграничните загадувања со опасен отпад и негово депонирање и Амандман на Анекс I АнексVIII $и$ АнексIX/ Amendment to the basel Convention on the Control of Transboundary Movements of Hazardous Wastes and Their Disposal. Амандманите се ратификувани со Закон за ратификација (Службен весник на Р.М. бр. 49/04)

- Стратегија за управување со отпад на Република Македонија (2008-2020) година (Службен весник на Р.М. бр. 39/08)

- Национален план за управување со отпад (2009-2015) на Република Македонија (Службен весник на Р.М. 6р. 77/09)

- Закон за управување со пакување и отпад од пакување (Службен весник на Р.М. бр. 161/09)

Во Скопје во јануари 2016 година е донесен План за управување со отпад на град Скопје за 2016-2020 [49]. Тој план се фокусира на следните точки:

- Подигање на јавната свест за одговорно управување со отпад

- $\quad$ Собирање, транспорт и складирање на отпад

- $\quad$ Третман/ преработка на селективно собраните фракции на комунален отпад

- $\quad$ Отстранување на отпад

- Институционално зајакнување

- $\quad$ Контролни и санкциони мерки при управување со отпад

- $\quad$ Управување со индустриски отпад

- $\quad$ Градежни материјали кои содржат азбест и управување со отпад од градење и рушење

- $\quad$ Финансиски аспекти на управувањето со отпадот 
- База на податоци, мониторинг на спроведување, информирање на јавноста и ажурирање на планот

- Корекција на локални прописи "

\subsubsection{3. Статистики според Министерството за животна средина и просторно планирање}

Во извештаите од Министерството за животна средина е напоменато дека многу од институциите кои се обврзани да доставуваат годишен извештај за постапување со отпадот, не го прават тоа. Поради што е тешко да се дојде до прецизни информации. Податоците добиени за 2018 година од 103 деловни субјекти кои постапуваат со отпад го покажуваат следново[48]:

\section{Табела 5.}

Состојба со увоз и извоз на отпад во Македонија

Увезен отпад 21167,38 тони *нема опасен отпад

Извезен отпад 128.297,76 тони од кои 1.278,01 опасен отпад

Извозот на отпад е доминантен во споредба со увозот на отпад во Република Северна Македонија.

\section{Табела 6.}

Преработен комунален и друг вид неопасен отпад во 2018

Отстранет

Компостиран

Рециклиран (хартија, картон, стакло, пластика и метал)
472 556,1тони или 99,3\%

745,5тони или 0,7\%

2383,97 тони

Подетални податоци се достапни само за 2017 година и тоа се добиени од четири колективни постапувачи. Исто така, проценките за целите се направени врз база на доставените податоци од колективните постапувачи. [48]

\section{Табела 7.}

Податоци за рециклирани материјали во 2017година

\begin{tabular}{ccc}
\hline Стакло & 2137,32 & $18,86 \%$ \\
\hline Пластика & 6615,05 & $33,01 \%$ \\
\hline Хартија/Картон & 19855,88 & $85,18 \%$ \\
\hline Метал & 388,09 & $13,16 \%$ \\
\hline Дрво & 0 & 0 \\
\hline Композитни материјали & 0 & 0 \\
\hline Друго & 0 & 0 \\
\hline Вкупно & 28996,34 & $42,07 \%$ \\
\hline
\end{tabular}

До крајот на 2020 година е во план да се рециклираат следниве количества на материјали од кои се произведуваат опаковки: 60\% стакло, 60\% хартија и картон, 50\% метали и $15 \%$ дрво. 
Табела 8.

Состојба со преносни автомобилски и индустриски батерии и акумулатори во 2017 година

\begin{tabular}{llll} 
Пуштени на пазар & собрани & рециклирани & извезени \\
\hline 3543971,81 кг & $4297630,70 \kappa г$ & $4220865 \kappa г$ & $67980 к г$
\end{tabular}

* Податоците се од извештаите на колективните постапувачи, самостојните постапувачи и малите производители БА(1) батерија и акумулатор ОБА(2) отпадна батерија и акумулатор.

\subsubsection{4. Стратегии за справување со отпадот во Македонија}

Стратегијата на Македонија за решавање на проблемот со отпадот во моментов е насочена главно кон изградбата на регионалните депонии. Во нови осум региони треба да бидат изградени депонии со стандарди за заштита на животната средина, со помош на фондови. И покрај тоа дека средствата и документите се обезбедени, дел од општините се противат. Доколку општините не се согласат за локациите, ќе бидат потребни дополнителни средства за изработка на технички проекти [32].

Според истражување објавено на медиуми [33], спроведено за институциите за тоа што вистински се рециклира во Македонија, резултатите се дадени во табела 9:

\section{Табела 9.}

Што вистински се рециклира во Македонија

\begin{tabular}{|c|c|}
\hline Електроника и машини & $\begin{array}{l}\text { Компаниите работат според Законот за Управување со електрична и } \\
\text { електронска опрема и тврдат дека сите апарати се рециклираат или деловите } \\
\text { од него кои се рециклабилни }\end{array}$ \\
\hline Пластика & $\begin{array}{l}\text { Поради малата количина на отпад (бидејќи сме мала држава) како и скапите } \\
\text { инсталации за преработка и немање поддршка од државата за } \\
\text { субвенционирање, кај нас се рециклира само прозирна РЕТ пластика } \\
\text { (шишињата за вода). }\end{array}$ \\
\hline Хартија & $\begin{array}{l}\text { Добиениот одговор е дека се' се рециклира, со додатен коментар дека } \\
\text { капацитетите кај нас се ниски. }\end{array}$ \\
\hline Стакло & $\begin{array}{l}\text { За овој материјал не е добиен конкретен одговор, освен тоа дека нешто се } \\
\text { рециклира, а за друго нема капацитет. }\end{array}$ \\
\hline Метал & Нема одговор \\
\hline
\end{tabular}


Табела 10.

Институции и компании во град Скопје кои се занимаваат со менаџирање на отпадот

\begin{tabular}{|c|c|}
\hline Компанија & Услуги кои ги нуди \\
\hline $\begin{array}{l}\text { ЈП „Комунална } \\
\text { хигиена“- Скопје }\end{array}$ & $\begin{array}{ll}\text { - } & \text { Собирање комунален отпад } \\
\text { - } & \text { Чистење на јавни сообраќајни површини } \\
\text { - } & \text { Селекција на отпад и трансфер центри } \\
\text { - } & \text { Собирање на кабаст отпад и градежен шут } \\
\text { - } & \text { Третман на животни скитници } \\
\text { - } & \text { Третман на фекални води }\end{array}$ \\
\hline Депонијата Дрисла & $\begin{array}{ll}\text { - } & \text { Обработка и отстранување на безопасен отпад; } \\
\text { - } & \text { Депонирање комунален отпад, } \\
\text { - } & \text { Собирање на опасен отпад; } \\
\text { - } & \text { обработка и отстранување на опасен отпад: одлагање на отпадот, негово } \\
& \text { планирање, набивање, покривање со инертен материјал со дебелина од } 30 \\
\text { см. } \\
\text { - Собирање, транспортирање и согорување на медицински отпад, } \\
\text { - } \quad \text { Депонирање на азбест. }\end{array}$ \\
\hline Ново метал & $\begin{array}{ll}\text { - Откуп на метал, акумулатори, електронски отпад, хартија, стари } \\
\text { автомобили, } \\
\text { - } \text { отпадна електрична и електронска опрема, } \\
\text { - } \quad \text { отпадни батерии и акумулатори, } \\
\text { - } \quad \text { отпадни масла - собирање, } \\
\text { - } \quad \text { управување со електронски отпад }\end{array}$ \\
\hline ЕлКолект & $\begin{array}{l}\text { - Лиценциран колективен постапувач кој поседува дозвола за постапување } \\
\text { со отпадна електрична и електронска опрема, отпадни батерии и } \\
\text { акумулатори }\end{array}$ \\
\hline Екоцентар 97 & $\begin{array}{l}\text { - откуп, собирање и примарна преработка на отпад кој содржи обоени и } \\
\text { необоени метали. } \\
\text { - собирање на отпад од електрична и електронска опрема, искористени } \\
\text { возила, акумулатори, батерии и кабли. }\end{array}$ \\
\hline Пакомак & - управување со отпадот од пакување \\
\hline Еко енерџи систем & Компанија со многу широк дијапазон на рециклирање лоцирана во Кавадарци \\
\hline Гринтех МК & $\begin{array}{l}\text { Најголема групација за рециклажа на пластика во Југоисточна Европа, во } \\
\text { Македонија постојат од 2007ма година. Лидер во државата во рециклирање на } \\
\text { ПЕТ, ПП И ПЕ. }\end{array}$ \\
\hline DS Smith & $\begin{array}{l}\text { Најголемата компанија за рециклирање хартија и картон во Европа и водечки } \\
\text { провајдер за целосно рециклирање и управување со отпад. }\end{array}$ \\
\hline Еко циркон & $\begin{array}{l}\text { Приватна компанија регистрирана во } 1997 \text { година со основна дејност откуп и } \\
\text { преработка на секундарни суровини (железо, алуминиум, бакар, олово, бронза, }\end{array}$ \\
\hline
\end{tabular}


месинг, и други) од технолошки и индустриски отпад, како и ископ со тешка механизација.

\begin{tabular}{l|l} 
Акрон Доо & $\begin{array}{l}\text { Единствена компанија во Македонија што се занимава со третман на отпадно } \\
\text { стакло. }\end{array}$ \\
\hline Sunilens Dooel & $\begin{array}{l}\text { Компанија која се презеде иницијатива за собирање отпадно масло за готвење } \\
\text { од домовите. }\end{array}$ \\
\hline МаМаОргана & $\begin{array}{l}\text { Организирани два пунктови за собирање на органски отпад од кој се прави } \\
\text { компост во населбите Лисиче и Маџари. }\end{array}$
\end{tabular}

\subsubsection{5. Иницијативи за реупотреба}

\section{Табела 11.}

Компании во град Скопје кои започнаа иницијативи за реупотреба

Нашата Фарма

Задруга Наша Добра Земја

Дај, не фрлај
Нуди млеко во стаклена амбалажа која се реупотребува.

За пазарење кај нив, треба да се носи платнена торба, вишокот тегли од дома може да се користи при купување, или да им се поклони за пакување на нивните производи, или за рециклирање

Неформално самоиницијативно организирање на граѓаните за подарување нешто што не ви е потребно повеќе или не го користите.

\subsubsection{6. Неформални собирачи}

Неформалните собирачи собираат над $80 \%$ од рециклабилниот отпад директно од контејнерите. Според граѓанската организација „Ајде Македонија“ од три до пет илјади граѓани годишно живеат од оваа економска активност.

Откупните цени на рециклабилните материјали варираат. Хартијата е можеби најчест и најголем количински отпад за кој има голема побарувачка од откупувачите. Цената често варира и во просек се движи од 2 до 4 денари по килограм.

За алуминиум просечната цена се движи од 40-45 денари. Поретко се собира од неформалните собирачи поради тешкиот процес на селектирање заради нивната големина.

Постои значителен број на откупувачи на ПЕТ пластика во Скопје и во Македонија за пластични шишиња. Цената постигнува од 10 до 12 денари по килограм или во просек околу 250 денари за една голема вреќa. Цената на стаклото во зависност од категоријата се движи од 0,6 ден до 3 ден за кило.[51]

Покрај неформалните собирачи на хартија и пластика има и такви кои собираат стари предмети од домаќинствата, познати како „Старо Купувам“, кои откупуваат или транспортираат стар мебел или апарати од домаќинствата, железо и сл. [34] 


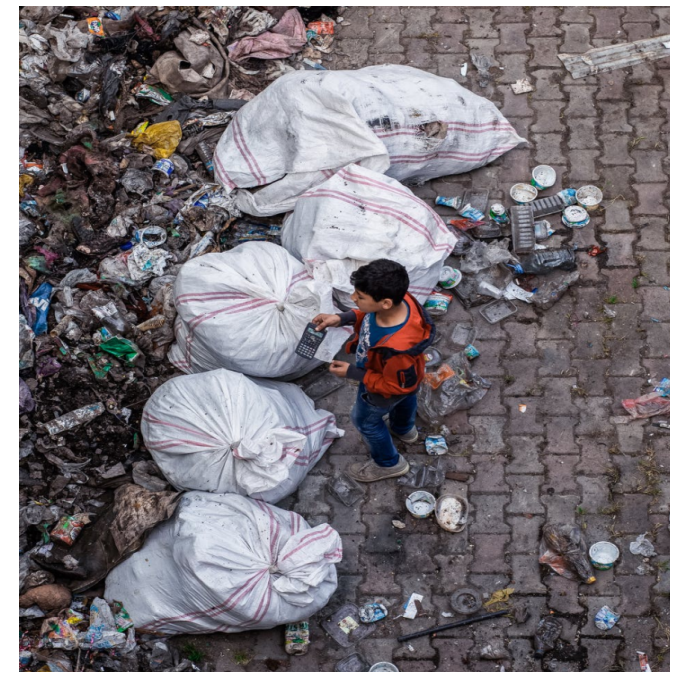

Сл. 30. Неформални собирачи

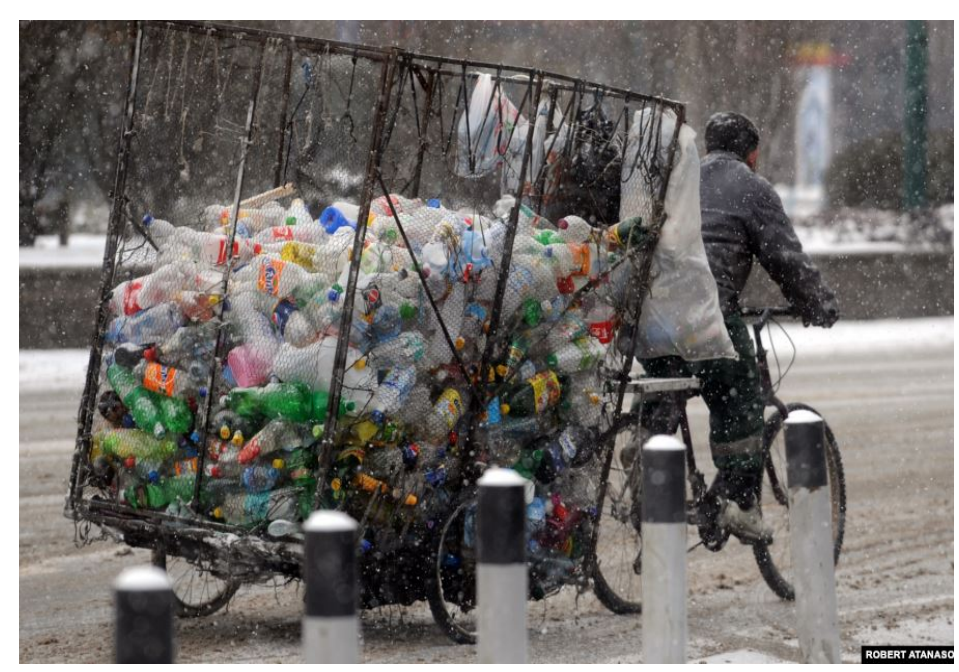

Сл. 31. неформален собирач со своето превозно средство Извор :slobodnaevropa.mk Robert Atanasovski(AFP)

\subsubsection{7. Диви депонии}

Дивите депонии се многу честа појава низ целата држава. Точниот број на депониите е тешко да се прецизира, а сигурно се брои во илјадници, додека многу од нив се со висок ризик за животната средина. Исто така, во руралните средини нема организирани системи за собирање на отпад, што значи дека тој завршува на селските буништа.

\subsubsection{8. Независни иницијативи и организации}

Постојат разни независни граѓански иницијативи, организации, здруженија и активисти кои сериозно се занимаваат со оваа проблематика. Недоволната ефикасност на институциите за одржување на урбаната средина чиста, многу често ги наведува членовите и граѓаните сами да се организираат за собирање на отпад од околината. Една од најпознатите групи „Не биди ѓубре“ со речиси пет илјади членови, неделно се организира низ разни локации за собирање и чистење на околината во и надвор од градот. Останатите често спроведуваат истражувања и ја критикуваат власта и надлежните за непреземање доволно мерки во врска со овој проблем.

Од Институтот за животна средина велат дека во Македонија годишно се создава околу 700 илјади тони отпад од кој 90\% завршува во дивите депонии. Се проценува дека ги има околу илјада такви во целата држава кои ги загадуваат водите, почвата и воздухот, додека и тие кои се регистрирани депонии не се добро организирани и опремени, поради што и процентот на загадување е многу голем. Исто така сметаат дека топлинската енергија која се испушта при согорувањето не се искористува правилно и ефикасно [53].

Според новинарот Бранко Прља проблемот со отпадот е многу видлив бидејќи тој се наоѓa секаде и не опкружува во секојдневието. Тој исто така вели дека е многу скептичен за тоа како 
навистина функционира рециклирањето во Македонија, и дали покрај тоа што овој процес би требало да ја зачува околината, на крај има спротивен ефект.[33]

Според истражување направено од Радио Слободна Европа, во Македонија не функционира целосно рециклирањето. Тоа е многу скап процес и, поради тоа што нема доволно голема количина за рециклирање, претежно се извезува. Дел од отпадот поминува низ долг процес на третирање, а дел се извезува директно најчесто во Хрватска, Бугарија, Романија итн. Материјалите за кои станува збор се стакло, хартија и пластика [32].

Од кампањата „НЕ ИГНОРИРАЈ.РЕАГИРАЈ“ информираат дека од целиот отпад 38.000 тони се пластика, а над 40.000 тони се стакло - цврст отпад за кој потребни се векови да се распадне. Од пластиката се рециклираат само 19\% (2.657 тони). Со нивно рециклирање би се заштедиле природните ресурси, нафта и многу киловати електрична енергија [53].

Овие информации драстично се разликуваат од податоците земени од Министерството за животна средина и просторно планирање.

Голем проблем е тоа што тешко може да се дојде до вистинити, точни или прецизни податоци, поради фактот дека институциите и покрај тоа што се обврзани да водат евиденција и даваат годишни извештаи, не го прават тоа. Сега за сега треба да ги прифатиме и да се задоволиме со информациите кои ги имаме, и покрај тоа што не го опфаќаат цело население, региони и отпад.

Рециклирањето, реупотребата и третирањето на отпад за жал сепак се гледа повеќе како бизнис, а многу помалку како потреба. Поради тоа што сме многу мала држава тие бизниси и не се толку профитабилни, што често доведува до решенија кои се моментално побрзи или полесни за спроведување. Ова може да се земе и како причина зошто голем дел од рециклабилниот отпад се извезува, а многу мал дел се рециклира локално. Додатна причина е таа дека компаниите често немаат доволен капацитет за задоволување на очекувањата за рециклирање.

\subsubsection{9. Истражување на мислењето на медиумите, каде тие го лоцираат проблемот со отпадот во Скопје}

Новинарката Нина Шуловиќ Цветковска пишува дека „ниту една комунална служба не е во можност да исчисти и одржува чист главен град доколку жителите не се однесуваат прописно и го фрлаат отпадот каде стигнат. Малите мини депонии се токму на овој начин настанати, а поради големата количина институциите не можат да постигнат да ги исчистат." Со овој напис Шуловска ги критикува граѓаните за нивното непрописно однесување, честа појава низ сите региони во градот, поради што се демотивираат и останатите кои ги почитуваат правилата [67].

Од порталот Капитал тврдат дека во Македонија само 10\% од целиот отпад се обработува додека јавноста е константно бомбардирана со пораки за подигање на свеста за рециклирање. Тоа укажува на недостатокот на транспарентност на информации кога се работи за оваа тема. 
Граѓаните не се информирани за тоа што точно, во колкава количина се рециклира или обработува отпадот, што го оправдува скептицизмот кај нив.[68]

Радио МОФ пренесува дека компанијата од Пакомак се жалат од неформалните собирачи дека ја уништуваат скапата опрема која што колективните постапувачи ја донираат на општините. Тие создаваат и лоша слика околу контејнерите каде го расфрлаат отпадот, а со тоа ги демотивираат останатите граѓани да го селектираат отпадот. Освен тоа, тие го собираат отпадот нелегално бидејќи не се евидентира, а често завршува во отпади кои работат без дозвола.[70]

Од друга страна медиумите информираат дека последните испитувања на почвата во Скопскиот регион укажуваат дека е контаминирана со олово, кадиум и арсен. Во зеленчуците и растенијата арсенот е застапен помеѓу 12-16 пати повеќе од дозволеното.[69]. Тоа укажува на фактот дека последиците од некоректно менаџирање и третирање на отпадот стануваат алармантни.

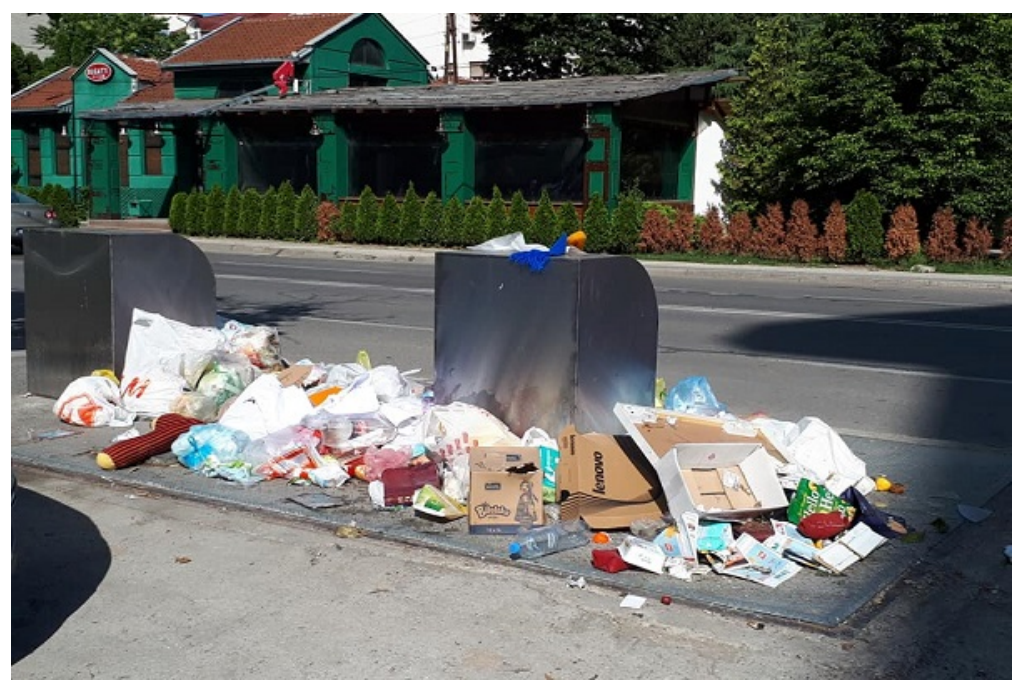

Сл. 32. отпад околу подземни контејнери 


\section{3. Фаза 3 - генерирање идеи}

Врз основа на извлечените заклучоци во претходните фази целта на овој креативен процес станува сосема јасна: да се дефинираат мерки и средства со кои ќе се подобрат состојбите со отпадот во нашите градови, преку:

- промена на навиките на граѓаните за начинот на третирање на отпадоците;

- подигање на нивото на едуцираност (од најмали нозе) како да се постапува со различни видови отпад;

- подигање на нивото на информираност за значењето на намалувањето на количините на отпадот во животната околина, колку е тоа значајно за заедниците, за поединците, за идните генерации;

- подигање на мотивираноста за правилно постапување со отпадот;

- воведување на санкции за неправилно постапување со отпадот.

\subsection{1 Бреинсторминг}

Од извршеното детално истражување од повеќе гледни точки на учесниците во создавањето на проблемот со лошото менаџирање на отпадот во нашиот град, спроведен е бреинсторминг на предлози кои би можеле да дадат придонес во решавањето на истиот, класифицирани според соодветната одговорност.

\section{Предлози за кои е неопходна поддршка од државни институции:}

- Мотивирачки иницијативи за стекнување навики за селектирање отпад (пример за тоа е спроведената кампања „донеси пет батерии - добиј бесплатна влезница за Зоолошка Градина“).

- Совесно спроведување до крај на било кој усвоен проект, со реални а не фиктивни резултати и со долгорочни ефекти.

- Воведување на екстремно високи парични казни за неовластено и несовесно фрлање на отпадоци, шут, пластика и други специфични видови отпад. Ригорозни казни на лица што оставаат градежен шут, апарати и стар мебел на улици, ниви, државно земјиште и други јавни простори. Зголемени инспекциски контроли низ населбите, опомени и казни за несовесните граѓани.

- Ригорозни казни за загадувачите.

- Забрана за увоз на отпад.

- Зголемување на цените на пластичните кеси и шишиња.

- Намалување на цените и субвенции за сите што користат реупотребливи амбалажи, торби, производи без пластика. 


\section{Предлози за кои е неопходна поддршка од образовните институции:}

- Воведување образовни програми во претшколските установи, основните и средните училишта за запознавање и подигање на свеста кај младите луѓе за штетноста од разни видови загадувачки отпад, воведување мотивирачки активности за стекнување навики за заштита на животната околина.

- Едукација на децата уште од најрана возраст за процесот на рециклирање, зошто е добро да рециклираат, како да рециклираат, кои се материјали се рециклираат и како. Да се воведат задолжителни работни акции, настава во природа или други активности, при што децата ќе бидат мотивирани на некаков начин да придонесат за подобрување на околината.

- Натпревари и работилници помеѓу учениците од исто или различни училишта на тема справување со отпадот.

\section{Предлози за кои е неопходна поддршка од компаниите кои се занимаваат со собирање и рециклирање на отпад:}

- Да се постават повеќе обележани корпи и контејнери за селектиран отпад во секоја улица и населба, трговски центри, паркови.

- Подобро обележани контејнери за селектирање отпад (контејнерите од Пакомак се многу лошо обележани, нејасни).

- Обезбедување повеќе екипи и опрема за справување со отпадот од страна на комуналните претпријатија.

- Обезбедување на подобро уреден простор наменет за контејнери за отпадоци (по можност истите да бидат подземни), да не бидат поставени како до сега на самата улица или тротоар, каде има поголем сообраќај, со цел да им се даде можност на граѓаните да посветат повеќе време на сортирање на отпадот, но и да не се растура по околината од страна на несовесни граѓани и од страна на животните.

- Да се усвои позитивниот пример од Љубљана, каде на секое место предвидено за одлагање на отпадоците од домовите се користат 3 вида контејнери за селектиран отпад и 1 за општ. При тоа, фрлањето на сортиран отпад не се плаќа, а за несортираниот отпад се наплаќа преку картичка во специјално дизајниран контејнер.

- Воведување временска рамка за одлагање и собирање отпад, казни за непочитување на правилата.

- Задолжителна едукација за селектирање отпад (преку интернет, телевизија, радио и сл.).

- Запознавање на јавноста со тоа што се случува со отпадот ако се фрли на погрешно место, а што ако се фрли на соодветно место, преку флаери, плакати, информативни видеа преку јавните медиуми итн.

- Вклучување на неформалните собирачи (луѓето што самите селектираат отпад од обичните контејнери) во работата на отпадните центри, нивно пријавување и добивање редовен надомест за извршената работа.

- Поставување на корпи за компостирање за собирање на органскиот отпад. 


\section{Предлози за кои е неопходна поддршка од самите граѓaни:}

- Самоиницијативни акции за чистење на околината околу нивните домови.

- Акции за подарување и продажба на стари предмети (по примерот на garrage sale).

- Акции за хортикултурно уредување на просторот околу нивните домови или изработка на урбана опрема со употреба на стари предмети.

- Креативни хоби центри за изработка на предмети од рециклирани материјали.

\subsection{2 Првични предлог концепти}

По извршената анализа на предложените мерки класифицирани според одговорноста во реализирање и спроведување на истите, се премина кон дефинирање на поконкретни предлог концепти за решавање на проблемот, според истите категории.

\section{Предлог концепт решенија кои зависат од Институциите}

Институциите се најмоќни за решавање на оваа ситуација, па затоа се предлага посериозно да се вклучат во процесот. Како за почеток доволно би било воспоставување правила и воведување санкции за сите кои не се однесуваат прописно, ставајќи најголем акцент на одговорно менаџирање и третирање со отпад, како и посериозно и прецизно евидентирање на ситуацијата. Институциите можат да влијаат на подобрување на ситуацијата на повеќе фронтови:

- Воведување на задолжителни предавања во училиштата за да научат и стекнат навика децата од што помала возраст.

- Данок - Намалување на данокот за сите компании кои се занимаваат со рециклирање, третирање или менаџирање на отпадот.

- Соработка со куќните совети - Еден од најклучните партнери во било кој од овие процеси треба да бидат куќните совети. Тие треба да бидат искористени како ресурс и точка за директен контакт со граѓаните. Создавање на мрежа на куќни совети, каде претседателите на истите би учествувале како претставници на секој поединечен станбен објект и неговите жители, би можело да биде граѓанско тело одговорно за предводење на потребните промени во комуникацијата помеѓу институциите и граѓаните, учеството на граѓаните и отчетноста на институциите. 


\section{КОНЦЕПт бр. 1 Купување билет со одредена количина на отпад.}

Идејата за овој концепт е подржана од испитаниците во анкетата како идеја која би ги мотивирала и наградила луѓето за нивното вклучување во процесот на рециклирање. Исто така, се смета дека е многу добар почеток за промени во однесувањето и подигнување на културата. Може да биде искористена за разни типови на билети, следејќи го примерот на Нула Отпад каде за донесени 5 батерии се наградува со билет за зоолошка градина.

Опција 1: Планината Водно е секој ден посетувана од спортисти, ентузијасти, кои за жал генерираат големи количини отпад. Идејата е секој кој би собрал одредена количина на отпад качувајќи се до врвот на планината, за возврат да добие бесплатен билет за симнување со жичара.

Опција 2: Билет за JCП - да се преговара колкава количина на отпад би прифатиле за еден билет и колку би биле флексибилни да прифатат и други рециклабилни материјали.

\section{КОНЦЕПТ 6р. 2 Информирање на куќните совети и станарите}

Овој концепт подразбира да се применат сите достапни начини на информирање на граѓаните за:

1. постоечките процеси за справување со различните категории на отпад;

2. постапките, партнерите и корисниците кои ги вклучува секој од тие процеси;

3. начините на кои граѓаните можат да се вклучат во секој од тие процеси.

Овие информации би биле достапни во вид на:

1. инфографици, плакати, летоци и брошури во јавните простори, во влезовите на зградите;

2. рекламни кампањи преку радио, телевизија, социјални мрежи;

3. специјализирани веб локации или дополнителни веб страници на Постоечките веб локации на Институциите

\section{КОНЦЕПт бр. 3 Подобрување на јавната инфраструктура за собирање на отпадот}

1. Поставување подобро дизајнирани и обележани контејнери, во разни бои, лесно достапни и јасни како треба да се употребуваат. Препорачливо е да бидат подземни поради хигиена, естетика и сл.

2. Воведување на формални транспортни услуги наменети за транспортирање на специфични и проблематични категории на отпад.

3. Воведување пункт за кабаст отпад, локација со функција на центар за прибирање отпад од реновирање на станови, искршен инвентар и неупотреблив мебел од домовите и компаниите, како и разни видови електронски отпад и отпадни парчиња метал. Истиот би можел да биде употребен и како собирен центар за стакло, хартија, разни видови амбалажи, лименки и сл. Граѓаните би требало да бидат информирани за неговото постоење, неговата локација, пристапот до него, контактни информации и сл. Уште подобро доколку е обезбеден и превоз на поголемите парчиња или поголем број вреќи со шут. 


\section{Технолошки предлог решенија}

\section{КОНЦЕПТ бр. 1 Воведување автомати за рециклирање}

Следејќn го примерот на поразвиените европски земји поставување на автомати за собирање рециклабилен материјал во поголемите супермаркети е многу погодно, бидејќ супермаркетите се секојдневно посетувани од граѓаните. Владата најави дека во 2020 година ќе бидат поставени такви автомати низ целата наша држава. Овие автомати прифаќаат стандардизирани рециклабилни материјали (пластични шишиња, стаклени шишиња и тегли, картон, хартија, лименки). За возврат, наместо паричен надоместок, граѓаните би добивале купони, билети или ваучери за попусти за разни настани, продавници, ресторани, музеи итн. Ова би значело соработка и контрибуција на разни установи за придонесување во подобро менаџирање со отпадот, и мотивација на граѓаните преку наградување со необични или неочекувани работи.

\section{КОНЦЕПт бр. 2 Замена на обичните контејнери со отпадомати / рецикломати}

Воведување уреди кои би ги замениле обичните контејнери, со доволно голем капацитет за да ги собере сите видови на примарно селектиран отпад, со можност за алармирање доколку погрешен тип на отпад биде фрлен во несоодветна секција. Од еколошки причини добро би било да функционира главно на соларна енергија. Освен собирање на отпадот да има доволна моќност за компресирање на пластиката $и$ хартијата, како $и$ мелење, сушење и компостирање на органскиот отпад.

Ваквите уреди да бидат поставени и користени од една зграда или блок од згради - во зависност од економските можности. Најголемата предност на овој тип на уред е тоа дека отпадот би бил на самото место детално проверуван и спремен за финално одлагање. На овој начин се заштедува многу време и ресурси бидејќи собраниот отпад може директно да биде транспортиран во рециклирачките центри, со што се прескокнуваат трансфер центрите каде сега рачно се двои и проверува целиот отпад.

Оваа идеја наложува промена во системот за собирање на отпадот, кој теоретски ветува позитивен социјален импакт бидејќ би овозможил бизнис соработка помеѓу граѓаните или куќните совети од зградите, од една страна, и компании откупувачи/рециклирачи, од друга страна. Со заработката можат да бидат покриени трошоците на куќните совети.

КОНЦЕПт бр. 3 Скапоцена пластика - Креирање на центри за ЗД принтање, каде секој би можел од рециклирана пластика да создаде некој траен предмет кој му е потребен.

Примерот на Скапоцена Пластика е многу погоден да се примени на техничките факултети. Машинскиот факултет може да биде прв пример. Факултетот ги има соодветните ресурси за дизајнирање на машините, додека пластиката може да се собира од самите корпи за отпадоци во објектот. Машините би служеле за креирање прототипови за проектите на студентите или на самиот факултет. Идејата може да се развие до мало производство на производи дизајнирани од самите студенти. 


\section{Предлог решенија базирани на иницијативи и самоорганизирање на граѓаните}

\section{КОНЦЕПТ бр. 1 Креативен центар за рециклирање.}

Искористување на имагинацијата за претворање на стари предмети во нови функционални производи со нивна пренамена придонесува многу во редуцирањето на отпадот. Од рециклираните материјали може да биде креирана и цела јавна урбана опрема во градот. Креативниот центар е замислен како простор на пристапно место за граѓаните каде ќе можат сами или организирано да донесат и остават стари непотребни предмети (мебел, облека, апарати, покуќнина и сл.), собрани рециклирачки материјали (стакло, пластика, хартија, метални предмети), остатоци од градежни материјали итн. Цели на Центарот:

- Собирање и складирање на реупотреблив отпад;

- Хоби центар - поправање, пренамена или уметничка преработка на стари предмети во работилница снабдена со ситни алати и опрема (донирани, стари, но функционални). Голем бенефит за граѓаните би бил постоењето на простор, каде креативците би можеле да го користат своето слободно време во реставрирање, поправање или преработка на стари предмети и материјали, со цел на креативен начин да се продолжи животот на предметите за нивна повторна употреба. Ваквите хоби центри би имале одлична едукативна намена ако се користат и како работилници за деца и младинци за изработка на разни предмети од отпадни материјали (картон, хартија, стаклени и пластични шишиња, изработка на мозаици од стари и искршени плочки и сл.).

- Организирање саеми за „sеcond hand“ мебел, машини, домаќински апарати, облека, покуќнина итн., каде граѓаните би можеле да продаваат, поклонуваат, или разменуваат работи кои не ги користат повеќе. Саемите би може да се одржуваат неколку пати во годината, организирани според категоријата на изложените предмети.

- Хуманитарни центри - предметите кои би биле собирани со тек на време во, кои сеуште се во добра состојба, би можеле примарно да се користат за хуманитарни цели. Иако не се пренесува транспарентно по медиумите, свесни сме за состојбата на студентските домови, детските домови, затворите како и здравствените установи во нашата држава. Собраните предмети можат да бидат донирани за подобрување на условите во овие институции, како и за индивидуални тешки социјални случаи на луѓе кои останале без нивните домови.

Постоење на повеќе помали пунктови, кои би функционирале на ист начин низ сите општини во градот би било многу корисно за жителите. Како центри за рециклирање или пунктови за собирање може да се искористат стари објекти, напуштени, кои немаат никаква функција во моментот.

Доколку се појави потреба за градење на нови објекти, истите би можеле да бидат изградени од рециклирани градежни материјали или неупотребени вишок материјали во добра состојба, како остатоци при реновирање и изградба на станови итн.

Ваквите центри би можеле да се развијат и прошират во вид на рекреативни центри кои овозможуваат одржување разни активности, наменети за промовирање на здрав живот преку можности за спортски активности или траки со пречки (obstacle course). 
Мали забавни паркови креирани од стари предмети пренаменети на креативен начин би биле многу привлечни, како за децата така и за младите и повозрасните. Центрите можат да бидат градени врз депонии, на кои би било засадено многу зеленило за да се помогне на природата да го разгради отпадот.

\section{КОНЦЕПТ бр. 2 Едукативна и информативна Веб платформа}

Креирање на веб платформа која ги содржи сите потребни информации за компании кои се занимаваат со менаџирање со отпад (контакти и опис на нивна дејност), едукација (начини за справување со отпад, совети за рециклирање итн.). Со други зборови - да се презентираат на едно место сите потребни информации во врска со отпадот кои моментално не се многу достапни и видливи, како и можност за размена на информации, дискусии, пријавување настани, разни активности или опасности поврзани со проблеми во врска со отпадот.

\subsection{3 Оценка на предложените концепти и избор на најдобар за понатамошна разработка}

Со цел да се согледа интересот на граѓаните и како тие ги оценуваат понудените концепти беше извршено анкетирање на 150 испитаници. Резултатите се следните:

1. Најподдржана идеја е таа за постоење на центар отворен за јавноста, за собирање и складирање на сите видови на отпад.

2. Веднаш после првата, со 2 гласа разлика, е идејата за купување билети со одредена количина на отпад, поконкретно примерот со жичарата на Водно.

3. На трето место е намалувањето на даноци за компании чија дејност е рециклирање отпад

4. На четврто место е идејата за креирање на веб-страна која ги содржи сите информации во врска со менаџирање на отпад како и контакти од институции кои можат да помогнат.

5. На петто место е поставување депозитни автомати во супермаркетите е исто така високо на табелата , гласано од 63,5\% од испитаниците.

6. На шесто место е идејата за организирање саеми за „sеcond hand“ или користени продукти.

7. Вклучување на куќните совети во еколошки програми е пониско рангирано, исто како и организирање „Garage sales”.

8. $\quad 22,5 \%$ не би прифатиле да се однесуваат според правилата на Zero Waste.

9. Организирање работилници за поправање и пренамена на стари предмети е најмалку подржано. 


\subsection{4 Заклучок од извршениот избор на предлог концепти за решавање на зададениот проблем}

За остварување на скоро сите понудени предлог концептни решенија потребна е голема поддршка од институциите, како и нивна активна инволвираност. Поради временски долги процеси и формалности кои се неопходни за соработка со нив, овој труд мораше да се фокусира на решение кое може да се реализира независно од институциите, но и независно од граѓаните, а сепак да ги исполнува барањата кои произлегоа од соработката со сите нив кои беа вклучени во интервјуата, анкетите и работилницата.

По завршувањето на целиот процес на истражување и предлагање концепт решенија, може да се заклучи дека главен проблем е што граѓаните не се доволни информирани ниту мотивирани за тоа како правилно да го одлагаат отпадот, а воедно и дека едукацијата за проблемот со загадувањето е на многу ниско ниво. Со оглед на фактот дека живееме во времето на он-лајн информирање најдобра и најбрза солуција за овој проблем е креирање на веб платформа наменета за проблемите со отпадот во Скопје, која ќе има едукативен и информативен карактер, како и можност за иницирање разни активности, дискусии за разни проблеми и предлози за нивно решавање. Токму затоа беше дефинитивно избран за понатамошна разработка концептот за едукативна и информативна веб платформа. 


\section{4. Фаза 4 - прототипирање}

Четвртата фаза го опфаќа процесот на дизајнирање на прототип на предложената веб платформа, како најсоодветно решение преку кое треба да се исполнат голем дел од очекувањата и барањата, препознаени од страна на жителите на градот. Оваа веб платформа треба да обезбеди:

- Брз пристап до важни информации поврзани со отпад за сите граѓани на Скопје.

- Едуцирање за разни теми поврзани со отпадот и животната средина, како на пример: процесите на рециклирање, карактеристики на различни видови отпад, правилно одлагање и редуцирање на отпад итн.

- Пристап до формалните годишни извештаи за генерирање отпад и животната средина во нашата држава.

- Пристап до регистри на сите формални постапувачи со отпад.

- Информации за физички и правни лица кои се занимаваат со менаџирање на отпад и се отворени за соработка со клиенти (опис на нивната дејност, контакт информации и линкови до нивните официјални веб-локации).

- Листа на организации, иницијативи, групи, институции чиј главен интерес е зачувување на животната средина и намалување на отпадот (контакт информации и линкови до нивните официјални веб локации со цел полесно остварување на соработка доколку има интерес).

- Објавување на најновите информации/вести од нашата држава и светот поврзани со темата на веб-платформата.

- Објавување на настани кои се организираат со цел да се подобри и помогне справувањето со отпадот и зачувувањето на животната средина во Град Скопје.

- Форум - отворени дискусии, можност за интеракција помеѓу посетителите, за додавање идеи, прашања, дилеми, или самоиницијативно да се организира настан на оваа тема.

\subsection{1 Таргет група}

Со оглед на фактот дека сите податоци кои треба да бидат презентирани на предвидената веб платформа се однесуваат на главниот град, таргетирани се жителите на Скопје, при што се опфатени сите општини. Возраста или некоја друга карактеристика не претставува никакво ограничување во користењето на веб платформата.

\subsection{2. Основни барања на дизајнот на веб-платформата}

За да биде успешен како производ дизајнот на веб платформата треба да исполнува неколку критериуми и да ги задоволи очекувањата на корисниците. Тие барања се следните:

- дизајн кој привлекува внимание; 
- дизајн кој на прв поглед ја презентира целта на темата;

- мотивирачки слогани кои повикуваат на подобрување на навиките на граѓаните заради заштита на животната средина;

- потенцирање на важноста на правилното одлагање и менаџирање со отпадот;

- интерактивност помеѓу посетителите, споделување искуства, идеи, пријавување неправилности, организирање настани;

- добра систематизација и класификација на информациите од интерес за граѓаните;

- добра навигација низ веб-платформата;

- $\quad$ лесен домен за памтење.

\subsection{3. Организација на податоците}

Сите влезни податоци во оваа веб платформа се собрани во текот на неколкумесечно сериозно истражување направено во рамките на овој магистерски труд. Одвоени се и систематизирани податоците кои беа посочени и барани од самите испитаници и учесници во работилницата, кои се корисни за жителите на град Скопје. Податоците се од едукативен, информативен или известувачки карактер.

\subsection{4. Структура на веб-платформата}

Дијаграмот на структурата на веб-платформата презентира на кој начин се класифицирани сите собрани информации, сместени на посебни страници. Се состои од вкупно 8 главни и 17 споредни страници. Страниците Едукација, Информирање и Настани функционираат на принцип на блог. Најголемиот дел од податоците низ страниците водат до други официјални веб локации. Навигацијата низ веб-платформата е лесна и интуитивна. 


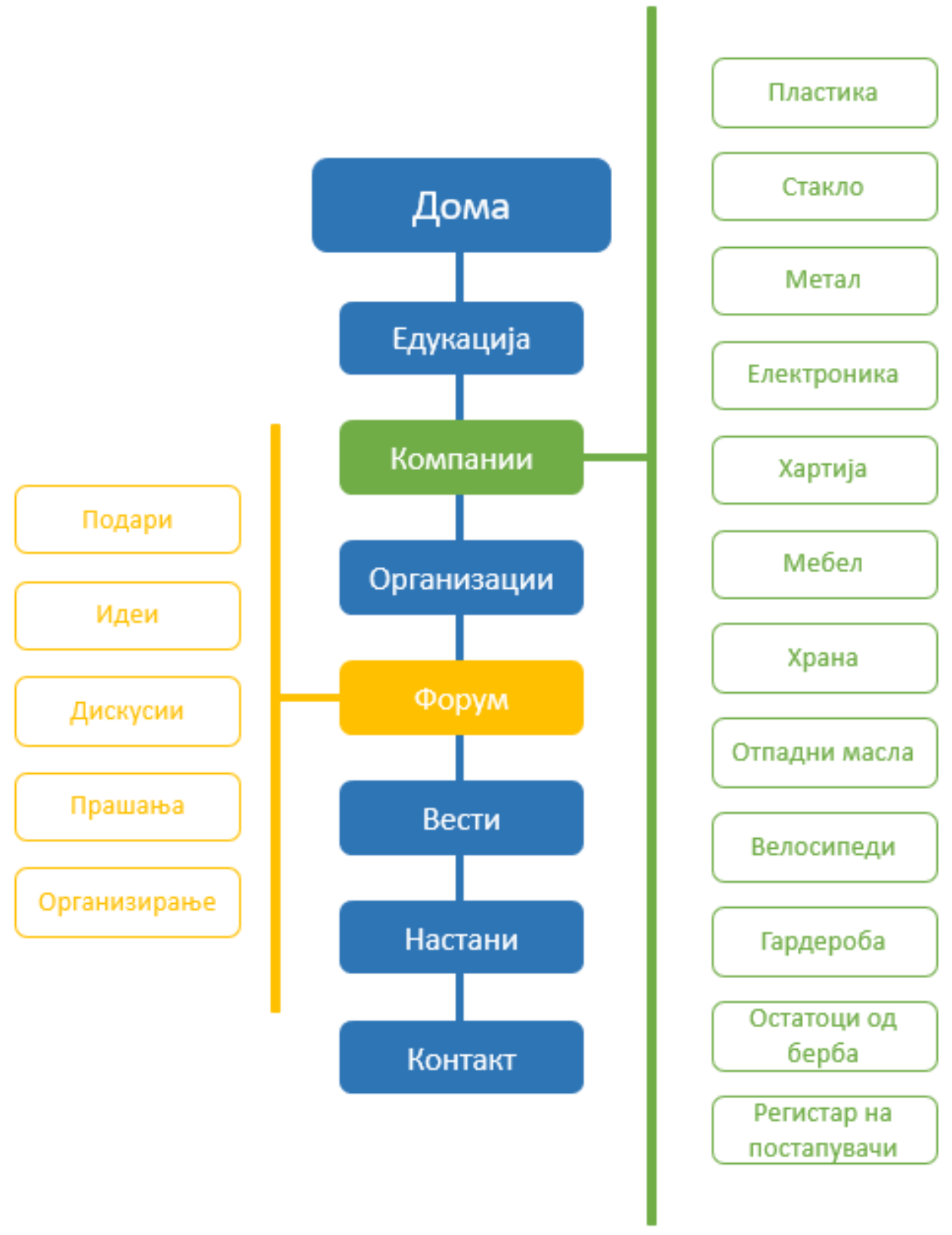

Дијаграм бр.21 Структура на веб платформата 


\subsection{5. Детална презентација на разработениот концепт}

Концептуализирањето и реализирањето на веб-платформата е водено во согласност со дефинираните барања чија цел е да се постигнат позитивни промени во општеството со примена на методологијата дизајн со општествено влијание.

Избор на софтвер за изработка на веб-платформата

Веб-платформата е изработена со примена на слободниот он-лајн софтвер WIX кој служи за изработка на веб-страни без професионална или програмерска помош. Овозможува креирање на HTML5 веб платформи како и страни за мобилни уреди. Големата слобода во дизајнирањето, како и разновидниот избор на апликации и теми го олеснуваат остварувањето на концептот или идејата и ја прават страната да изгледа професионална и комплетна.

Избор на тема на дизајнот

Поради пораката и целта на оваа веб-платформа, беше избрана темата од категоријата „Заедница \& Едукација,- Животна средина“. Поради едноставната навигација и јасно организираната структура оваа тема е најпогодна за користење од страна на било кој дизајнер, без разлика на неговото претходно знаење за креирање веб страни. Карактеристично за оваа дизајнерска тема е тоа дека секоја страна во позадина има слика од убава и чиста природа.

Избор на домен

Доменот МалкуПовеќе е инспириран од поодамнешно популарно интервју поврзано со неформално собирање на отпад. Доменот беше избран поради тоа што ја пренесува суштината на идејата - повеќе информации, додека со играта на двата спротивни збора „малку“ и „повеќе“ насловот добива хумористичен елемент кој го прави полесен за памтење. Веб-платформата нуди малку повеќе информации на едно место. (www.malkupoveke.wixsite.com)

Избор на палета на бои

Сината и зелената се боите на вегетацијата и небото, боите кои ги гледаме најмногу, бидејќи не опкружуваат секојдневно. Токму поради тоа, беше избрана таа палета на бои, која потсетува на природа, чистота, здравје и екологија. 


\section{Дизајн на поединечните страни}

Во горниот дел на страницата Дома е сместен банерот, каде левиот горен агол е резервиран за името на веб-платформата МалкуПовеќе. Во горниот десен агол се наоѓа менито составено од копчињата кои водат до страниците:

1. Дома (линк до страната индекс);

2. Информирање (линк до страната за вести и разни тековни информации),

3. Настани (линк до страната со информации за настани кои се случуваат во градот) и

4. Контакт.

Во позадината беше поставено кратко видео од густа чиста зелена природа, додека во преден план се појавуваат слоганите: „Информирај се“, „Преземи акција“ и „Направи промена“. Боите кои доминираат се сина, зелена, бледо жолта, и белата како боја за текстовите и деталите.

Страната Дома овозможува пристап до четирите главни страни:

1. Едукација,

2. Одлагање Менацирање, Рециклирање Отпад,

3. Институции, организации, Иницијативи,

4. Идеи, Коментари, Прашања.

Пристапот до нив е овозможен преку четири големи правоаголници во различни бои во вид на копчиња, сместени во долниот дел на страницата.

При лизгање надоле на страницата, заглавјето останува закачено на екранот со зголемена транспарентност на боите, со цел полесно и побрзо навигирање до другите делови. Подножјето содржи кратко објаснување за целта на веб-платформата и останува непроменето во сите останати страници.

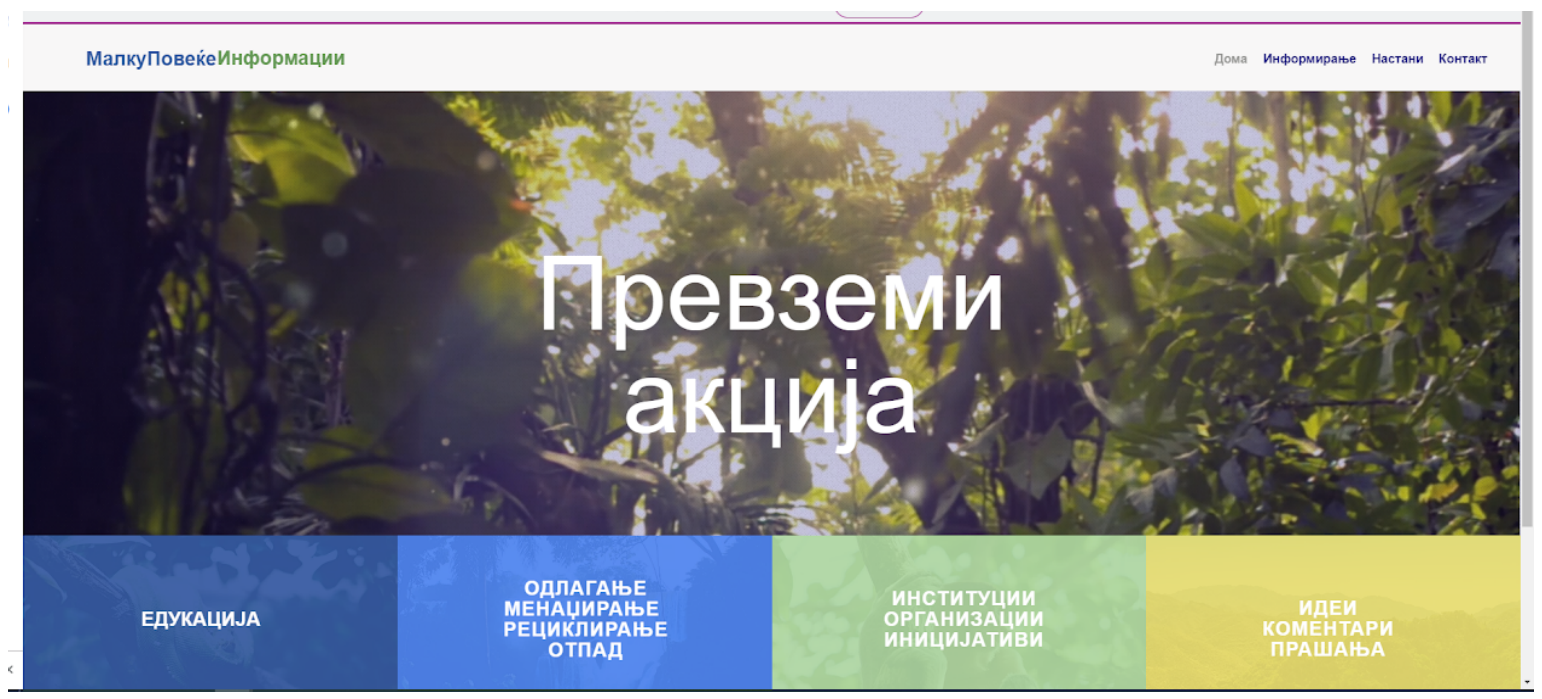

Сл. 33. Изглед на почетната страна на веб платформата 
Страната Едукација е дизајнирана во вид на блог каде се објавуваат едукативни постови на тема животна средина и отпад. Идејата е постовите да бидат кратки, јасни, разбирливи, брзи за читање, да можат да го одржат вниманието на читателот и одговорат неговите прашања. Се таргетира информирање за тоа како правилно да се одлага отпад, што може да се рециклира и што не, карактеристики на различни видови отпад, зошто пластиката претставува најголем проблем, процесите на рециклирање, совети за редуцирање на отпадот, нула отпад стил на живот и слично. Постовите се симетрично подредени во средина на страницата, прикажан е датумот на објавување, активирана е опцијата оставање коментари. Во десната вертикала се наоѓ квадратче со порака - објаснување за тоа што го нуди страната Едукација.

Позадината е фотографија од природа со бујна вегетација со зелен рептил, над неа е поставен филтер во боја за да биде во визуелна хармонија со дизајнерската тема. Постовите, пораките и заглавјето се истакнати така што се поставени врз бледо сива транспарентна позадина, за бидат јасно воочливи.

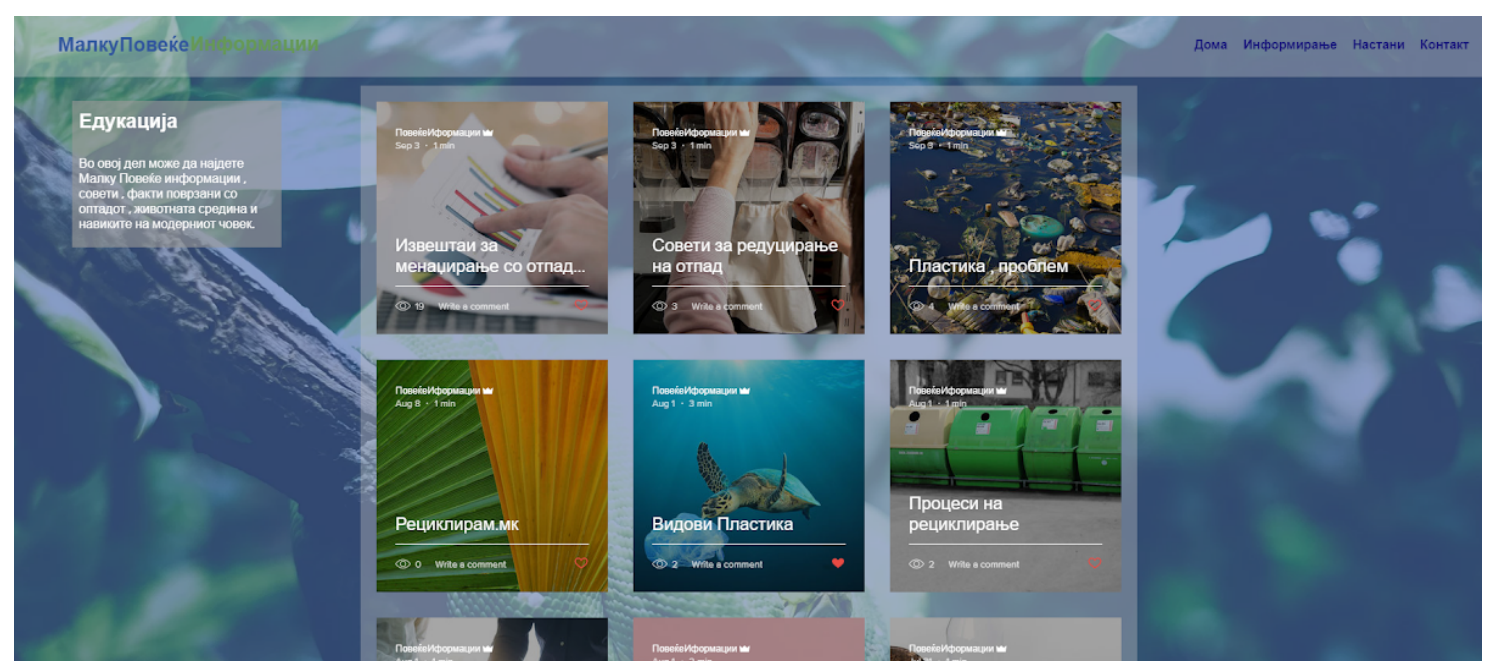

Сл. 34. Изглед на страната Едукација

Одлагање Менацирање Рециклирање Отпад е најважната страница на веб-платформата за сите оние кои селектираат отпад и се свесни дека двоењето на отпадот во уличните контејнери не функционира, или пак за тие кои сакаат да започнат да го прават тоа. Исто така, повеќето од нив често наидуваат на потешкотии кога сакаат да одлагаат некоја несекојдневна категорија на отпад поради недостатокот на информации.

На оваа страница се презентирани повеќе видови отпад по категории. Со кликање на соодветната слика се отвара посебна страница со информации за компании кои се занимаваат со менаџирање, рециклирање, откупување или собирање на таа категорија отпад. Повеќето големи компании најчесто соработуваат со големи клиенти, но има и такви кои примарно собираат отпад од поединци. Секоја од нив прифаќа или откупува отпад доколку тој е однесен до нивната локација, но многу од нив нудат транспорт или редовно го собираат отпадот од локацијата на клиентот /поединецот. 
На оваа страна можат да се најдат и мапи од локации каде има поставени контејнери за одлагање електронски или кабаст отпад, како и мапа со локациите на контејнерите поставени од Пакомак за собирање на отпадна хартија. На крај, поставена е слика со линк кој води до официјалната страница на Министерството за Животна средина и просторно планирање и нивниот официјален регистар на сите формални постапувачи со отпад.

Позадината, како и кај сите останати страни, е слика од природа, дрва , водопад, со обоен филтер за да се намали вниманието на самата слика и да се стави фокусот на слики за категоризираните видови отпад. На левата страна е поставен квадрат со порака која ја објаснува целта на одлагањето, менаџирањето и рециклирањето отпад. Сликите и пораките се разликуваат од позадината поради рамката со транспарентен сив филтер.

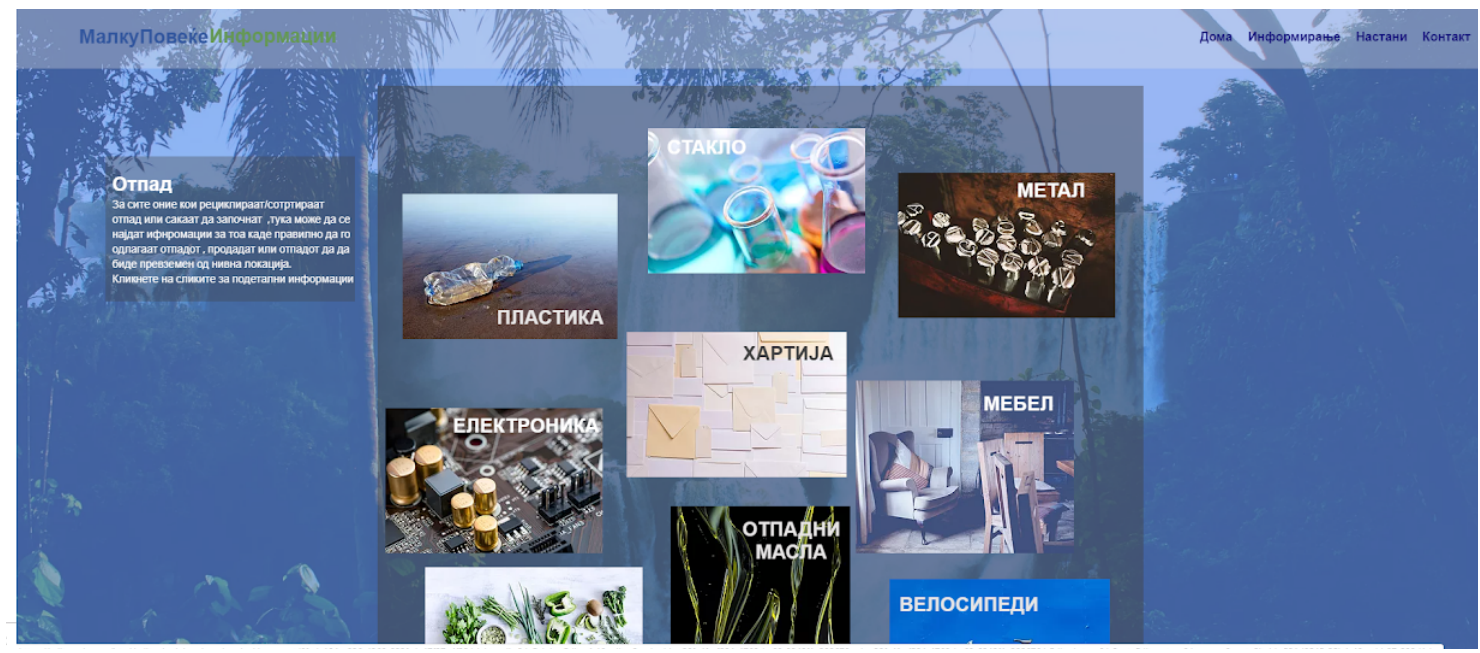

Сл. 35. Изглед на страната Одлагање Меначирање Рециклирање Отпад

Кликање на сликите со категории на отпад води до посебни страници со сличен дизајн, но различни содржини. Како пример може да ја земеме страната Пластика (сл.36). Во средина на страната се поставени логоата на компаниите кои се занимаваат со овој тип на отпад. Под самите слики има краток опис на дејноста на компанијата која би била од интерес на корисникот. На кратко се објаснува дали компанијата го рециклира, откупува или собира тој тип на отпад, како и телефонски број или е-маил за контакт за понатамошна соработка. Доколку се кликне на самите логоа се отвораат официјалните веб-страни на компаниите, каде може да се најдат многу подетални информации. Останатите страници со категории на отпад функционираат на истиот принцип (сл. 37. и сл. 38). Целта на страниците е само да информираат и да ги презентираат сите потребни податоци на едно место, додека за деталите останува на самиот корисник да ги осознае доколку има таква цел/желба.

За категоријата Мебел беше неуспешно да се дојде до информации за тоа дали има компании кои откупуваат и рециклираат мебел. Поради тоа за оваа категорија понуден е пристап до фејсбук групата „Дај не фрлај“ која поддржува и практикува поклонување мебел. Освен тоа дадени се информации за официјални локации каде може правилно да се одлага кабаст отпад, во кој спаѓа и мебелот. 


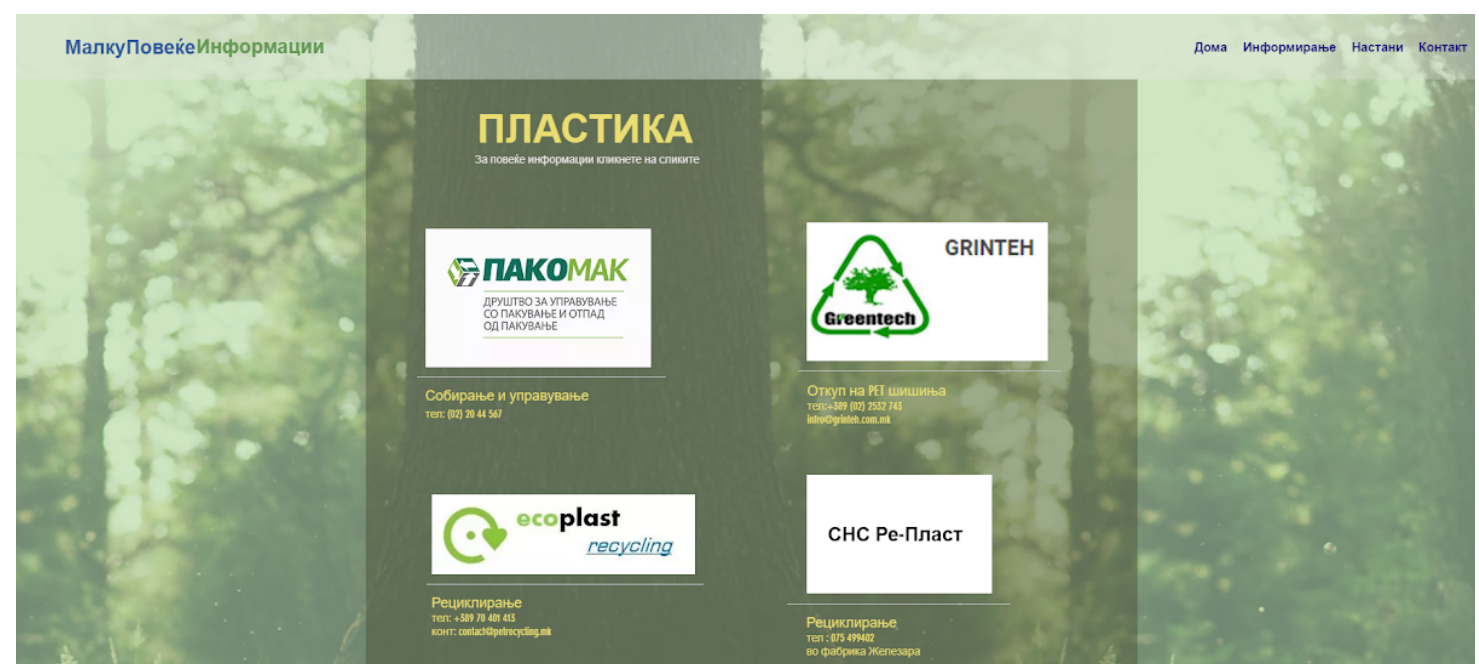

Сл. 36. Изглед на страната Пластика

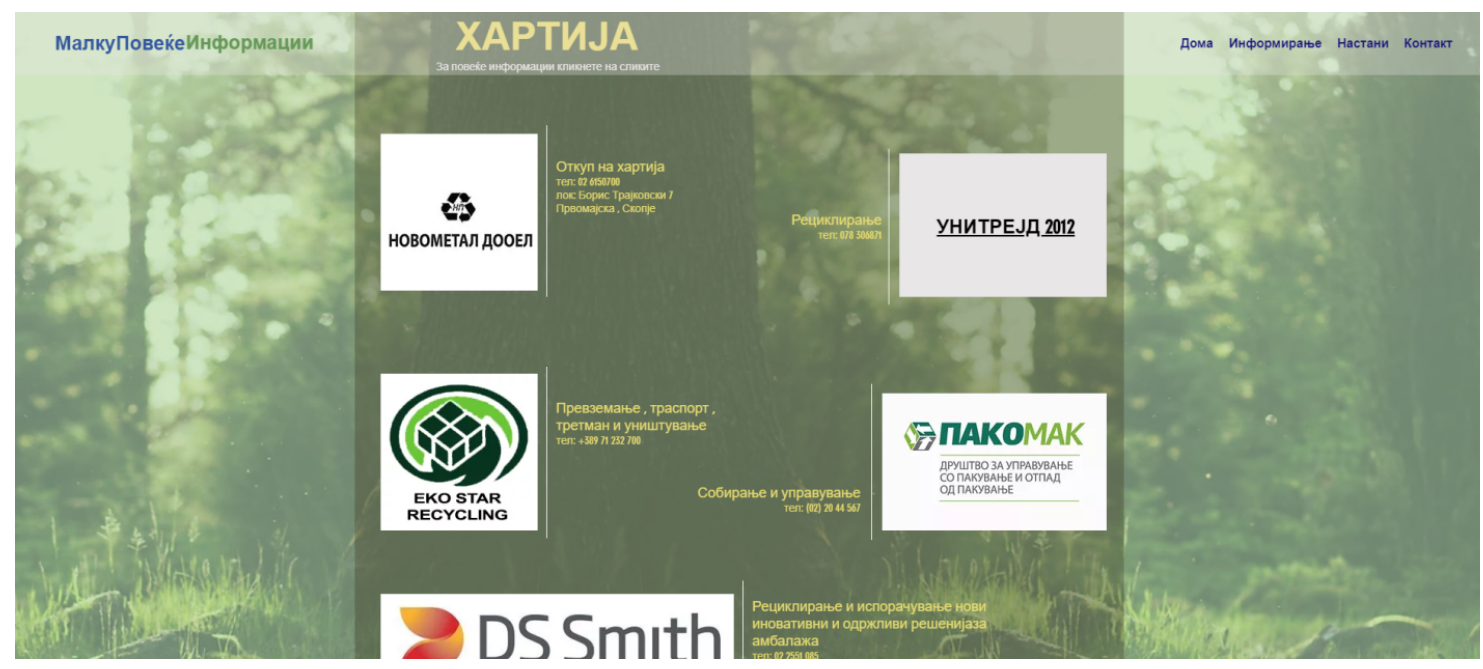

Сл. 37. Изглед на страната Хартија

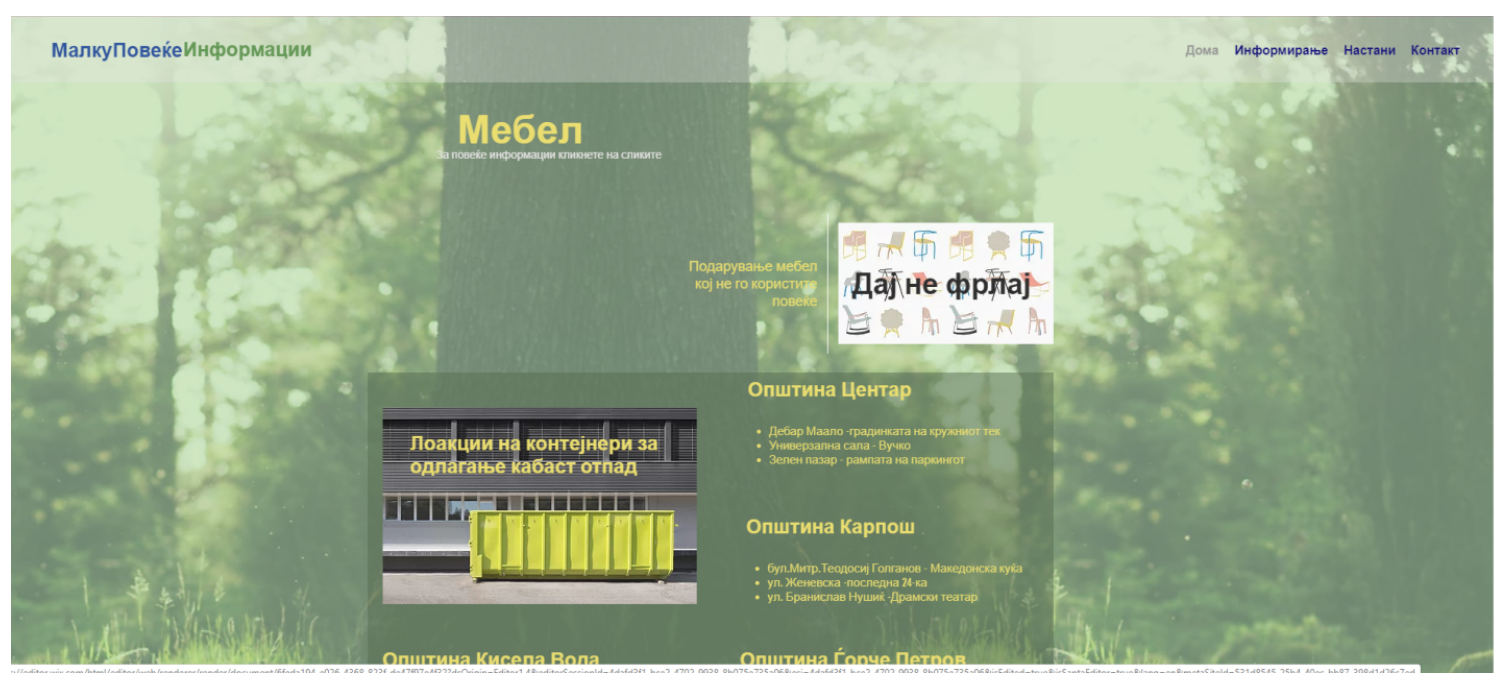

Сл. 38. Изглед на страната Мебел 
Страницата Институции, Организации и Иницијативи содржи листа на сите организации, институции, групи, иницијативи, здруженија, кои се занимаваат со третирање на проблемот со отпадот и загадувањето на животната средина. Претставени се во вертикални правоаголници, со слика од лого на чело и наслов под сликата. Помеѓу сликата и насловот е поставен банер кој со еден збор укажува дали се работи за јавно претпријатие, депонија, здружение, група и слично. Под насловот, со неколку зборови е објаснета суштината на нивната дејност, со што примарно се занимаваат, како и линк - Повеќе - кој води до нивните официјални веб-страни.

Оваа страница им овозможува на граѓаните кои имаат желба да направат нешто повеќе, да имаат целосна прегледност за тоа какви институции, групи или здруженија од оваа област постојат, кои се нивните цели и каде тие самите би можеле да се вклучат или да соработуваат со истите.

Визуелниот дизајн не се менува ни во оваа страница, позадината останува фотографија од зелени листови, покриена со филтер за да се пренасочи вниманието од фотографијата и фокусот да се насочи кон белите полиња со објави со логоа. Како и кај останатите делови, квадратот со пораката за појаснување на информациите кои се нудат во страницата е поставен во горниот агол на левата вертикала.

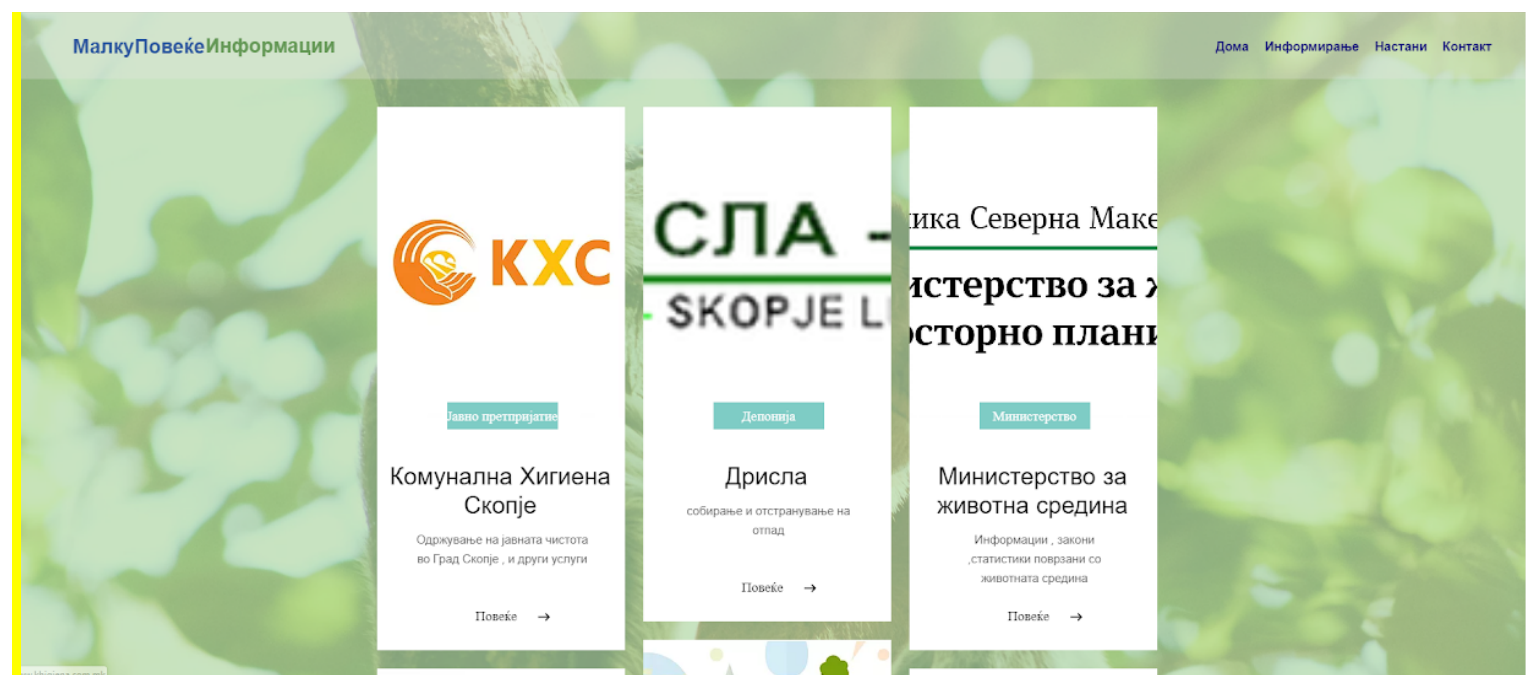

Сл. 39. Изглед на страната Институции, организации и иницијативи

Страницата Идеи, коментари, прашања е организирана во вид на форум. Кога се работи за вакви теми, важно е да се биде кохерентен со мислењата, потребите и идеите на жителите во градот. Најдобар начин да се реализира тоа е креирање и одржување форум, воедно и интеракција помеѓу посетителите. Целта на овој форум е да се воспостави комуникација и интеракција помеѓу посетителите и да се зајакне заедницата доколку се појави интерес. Со цел да биде појасен и подобро организиран форумот е поделен во неколку категории: 
Подари - во овој дел посетителите можат да објавуваат постови за поклонување на предмети кои нив не им се потребни повеќе и сакаат да ги подарат.

Идеи - место каде секој може да ги сподели своите идеи или да даде идејни решенија за некој проблем кој ја засега животната средина во градот.

Дискусија - слободен простор за разни дискусии на разни теми, пријавување неправилности, коментари кои не припаѓаат во другите групи, споделување искуства.

Прашања - поставување на прашања поврзани со темата на веб-платформата кои покрај админот можат да бидат одговорени и од другите посетители.

Организирање - се поттикнуваат посетителите, доколку имаат добри идеи, сами да покренат иницијативи и да се организираат за нивно остварување.

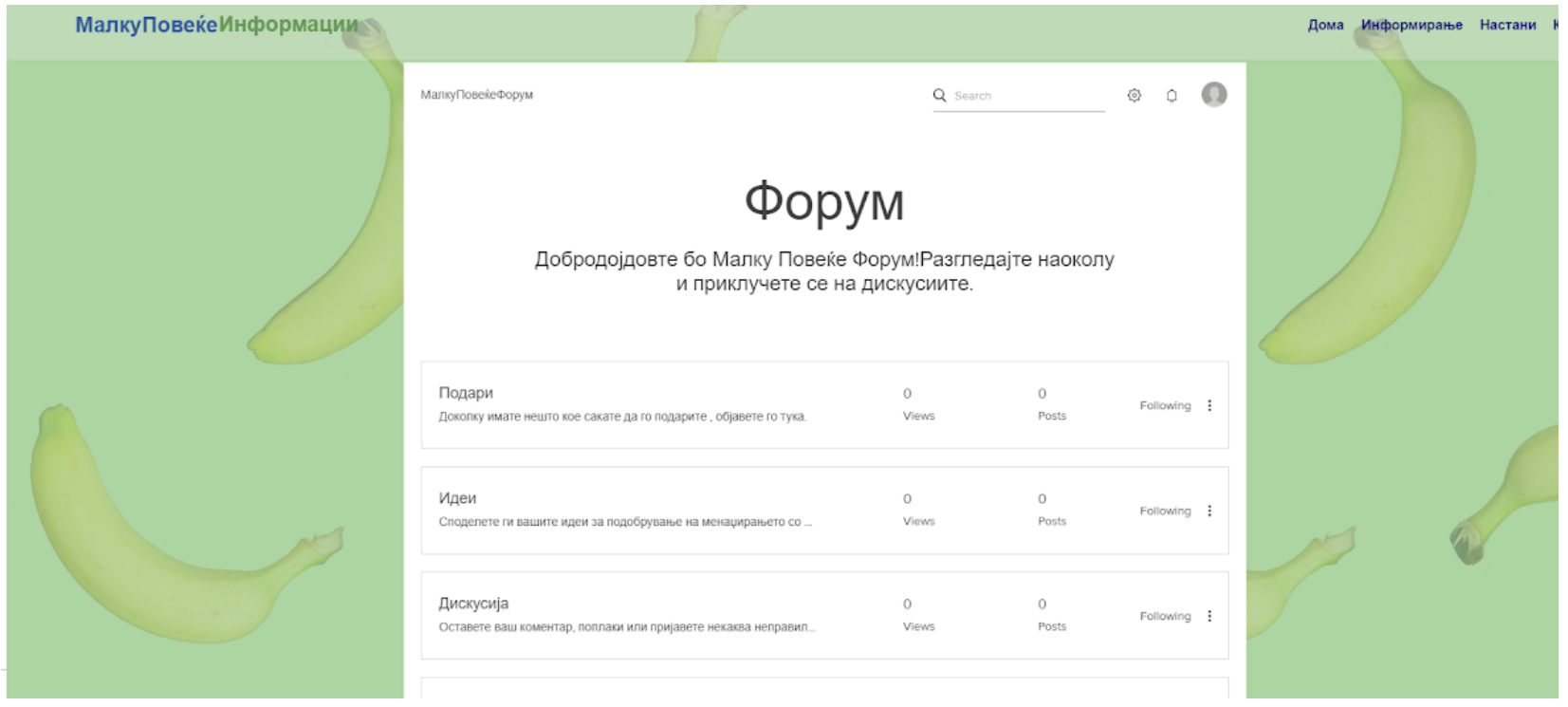

Сл. 40. Изглед на страната Идеи, коментари, прашања

Страницата Информации функционира на принцип на блог каде се објавуваат најнови вести, новости, измени и слично поврзани со темата на МалкуПовеќе. Актуелните иновации и новости, во светот или дома, во врска со менаџирање со отпад ќе бидат објавувани во оваа секција. Исто така ќе бидат објавувани и информации кои го засегаат градот Скопје, како на пример мапи од локации за собирање на типови отпад, апликации за пријавување отпад, најава за општинско организирано собирање отпад , промени во закон и слично.

Позадината на страната е слика од шума со зелен филтер, бидејќи зелената боја е доминанта во овој дизајн. Објавите се во форма на правоаголник подредени вертикално, со голема слика во левиот дел и наслов во десниот. Датумот на објавување е прикажан, а коментарите од посетителите се добредојдени. Како и во другите страници, во левата вертикала има објаснување за тоа што содржи страницата Информации. 


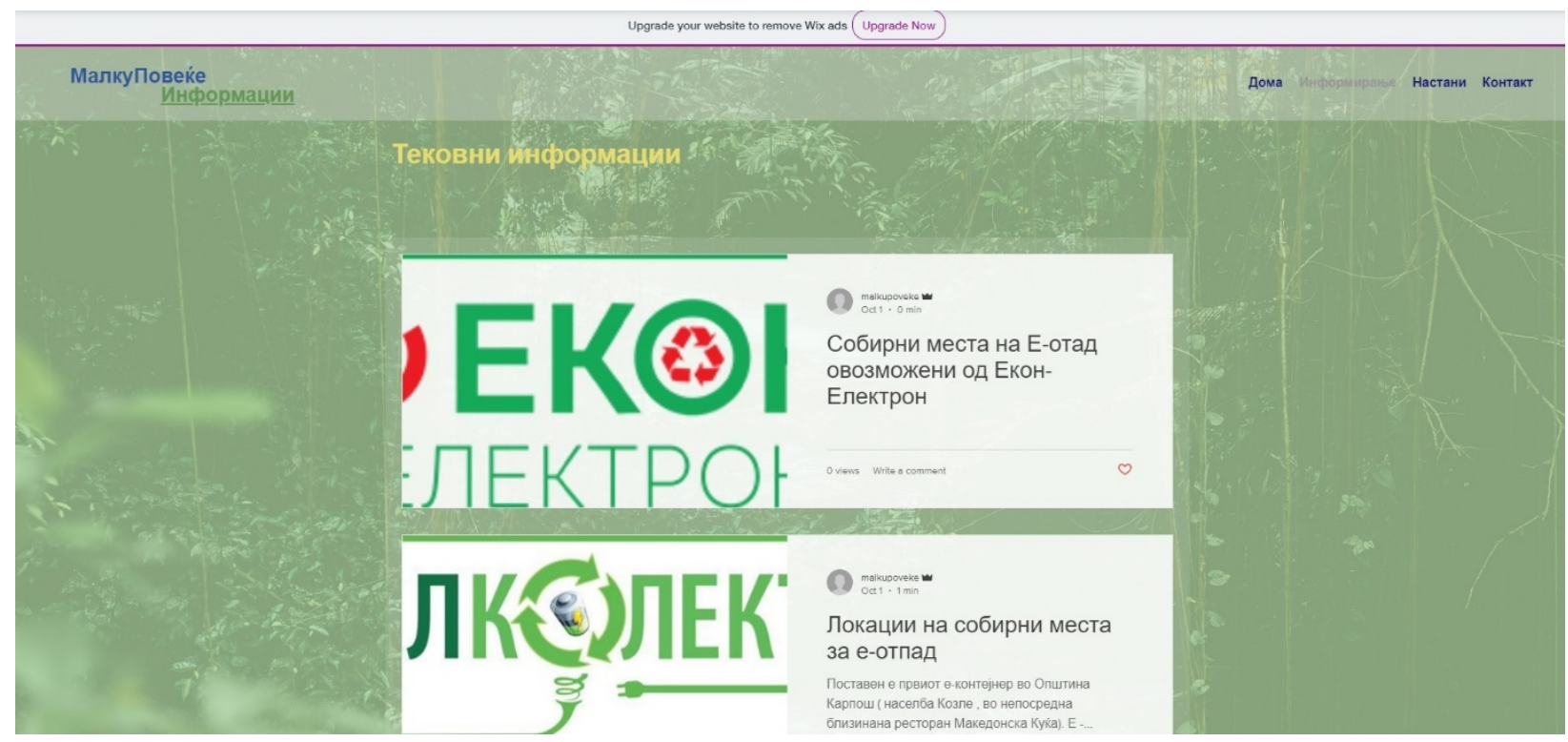

Сл. 41. Изглед на страната Информации

Страницата Настани е наменета за објавување на сите тековни настани во кои може да се вклучат или учествуваат посетителите. Настаните би биле од типот на подигање на свеста кај граѓаните, организирано чистење на животната средина, семинари, предавања, работилници, дискусии чија цел е третирање на проблемот со отпадот.

Објавите се подредени вертикално, со голема слика од темата на настанот и наслов со дата под сликата. Во објавата може да се даде детално објаснување за настаните, како и линк кој води до официјалните страни или регистрација за учество, доколку е потребна.

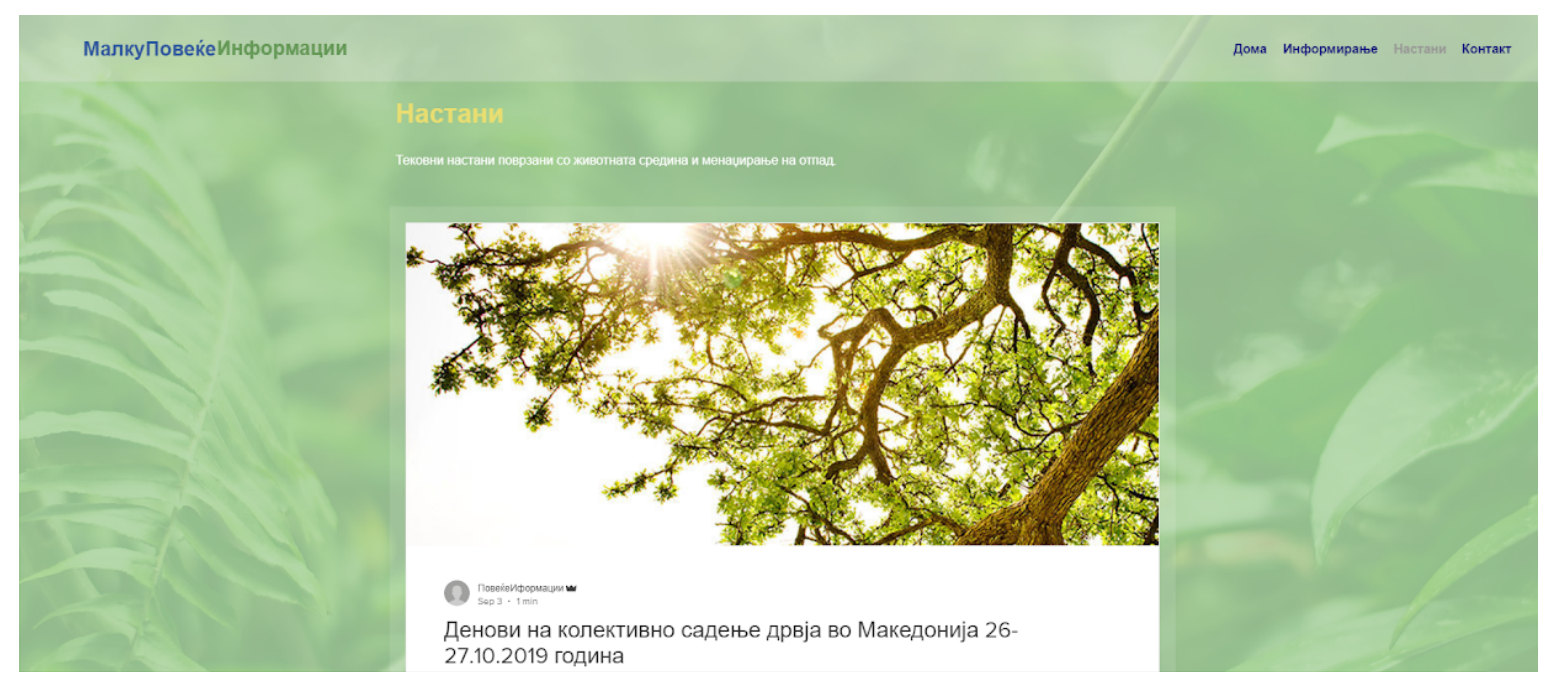

Сл. 42. Изглед на страната Настани 
Страницата Контакт содржи кратко објаснување за тоа како е родена идејата за креирање на МалкуПовеќе веб-платформата. Презентирани се информации за контакт, доколку некој има идеја или желба за соработка.

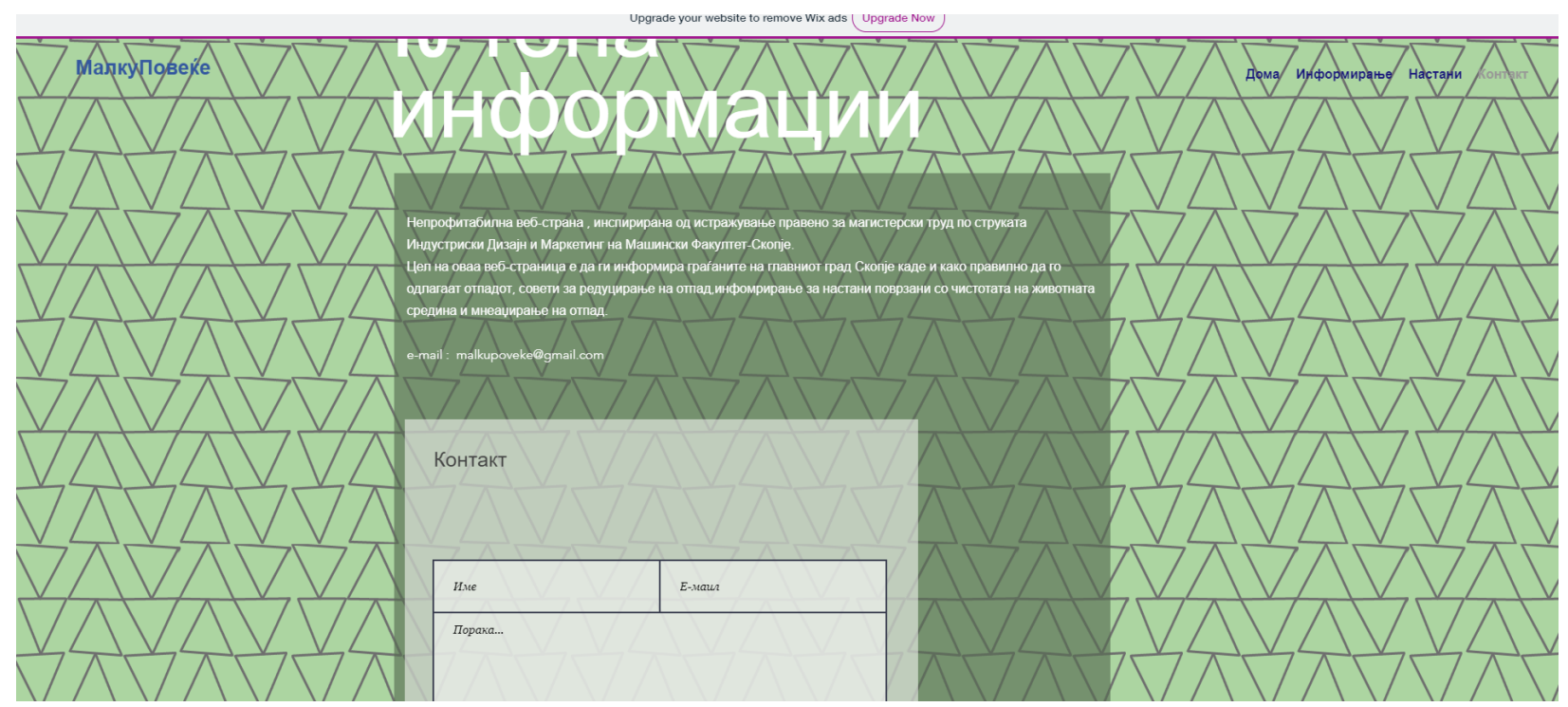

Сл. 43. Изглед на страната Контакт

\subsection{6. Понатамошен развој}

Доколку веб платформата се покаже како успешна, идејата е да се развие апликација од овој тип. Мобилната апликација би работела во принцип на регистрирање/бирање општина при што би се добивале редовни нотификации за настани, локации на контејнери или организирани општински собирања на отпад. Поради резултатите од анкетата од кои се гледа дека најдобар начин на промовирање/информирање е преку социјалните мрежи, страната е исто така развиена на социјалната мрежа Facebook.

\section{5. Фаза 5 - финализација и тестирање}

Во петтата фаза е извршена доработка на веб платформата. Десетина посетители на веб платформата ја разгледаа детално и дадоа свои коментари, корисни за подобрување на дизајнот. Тие имаа позитивни коментари во однос на структурата на веб платформата каде сите главни цели се добро осмислени и богати со корисни информации. Негативните коментарите беа главно насочени кон недоволно препознатливата цел на веб платформата поради несоодветен наслов. Другите забелешки се однесуваа на прејаките применети бои и неоригиналните фотографии во позадините на страниците, долгите називи на копчињата на страницата Дома.

Врз основа на собраните впечатоци од посетителите на веб платформата беа јасно дефинирани барањата за подобрување на дизајнот: 
- да се реформулира насловот на главната страна од Малку Повеќе Информации во Малку Повеќе за Скопје, за да биде појасна целта;

- да се променат (скратат и поедностават) насловите на копчињата во долниот ред на страницата Дома;

- $\quad$ да се намали интензитетот на боите на позадините;

- да се заменат фотографиите на позадините со автентични (од Скопје) и соодветни за темата, заради постигнување на оригиналност, единство на темата и визуелната информација;

- фонтот на текстовите да биде заменет со понежен и неболдиран;

- $\quad$ рамките околу главните копчиња да бидат тргнати.

За реализација на поставените барања беа направени нови фотографии од градот и околината во кои е забележителен контрастот помеѓу убавината на природата или градските пејзажи наспроти нечистотијата $и$ отпадот предизвикани од негрижата на граѓаните $и$ Институциите. Колоритот на страните останува непроменет, но интензитетот на боите е ублажен.

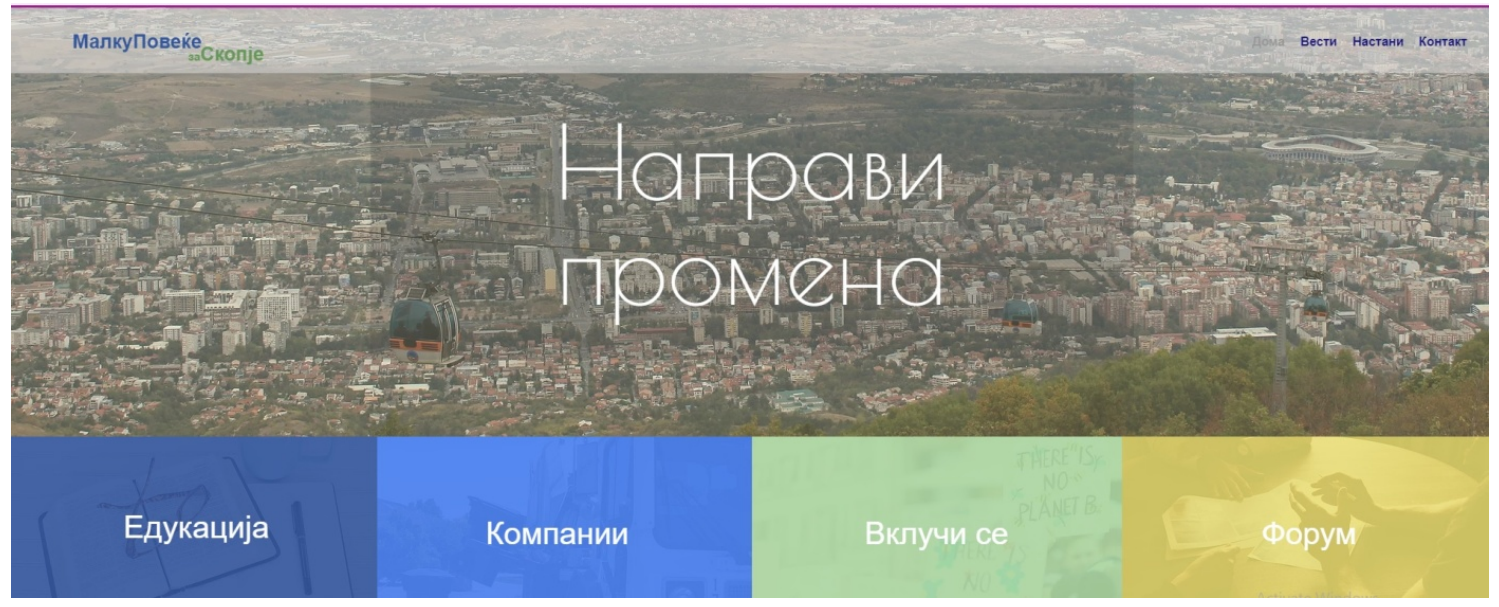

Сл. 44. Конечен изглед на почетната страна на веб платформата 


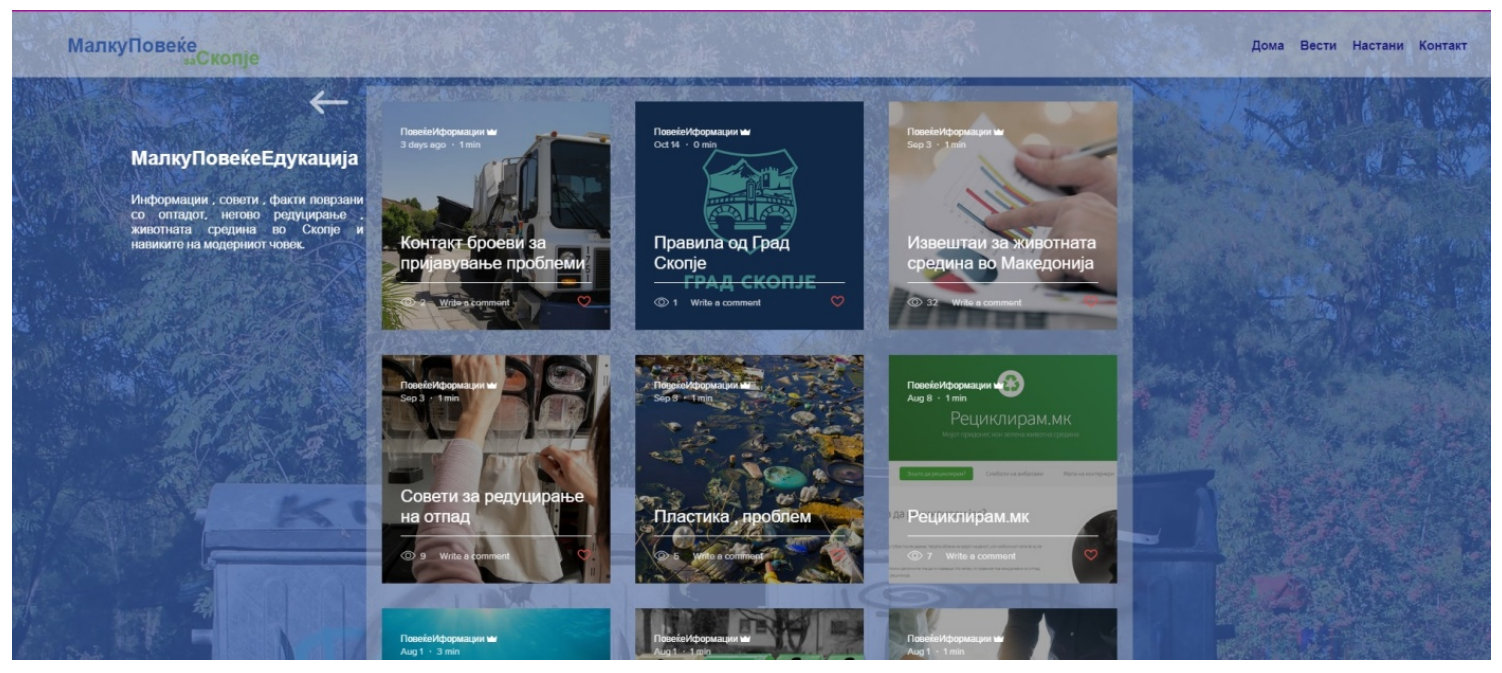

Сл. 45. Конечен изглед на страната МалкуПовеќеЕдукација

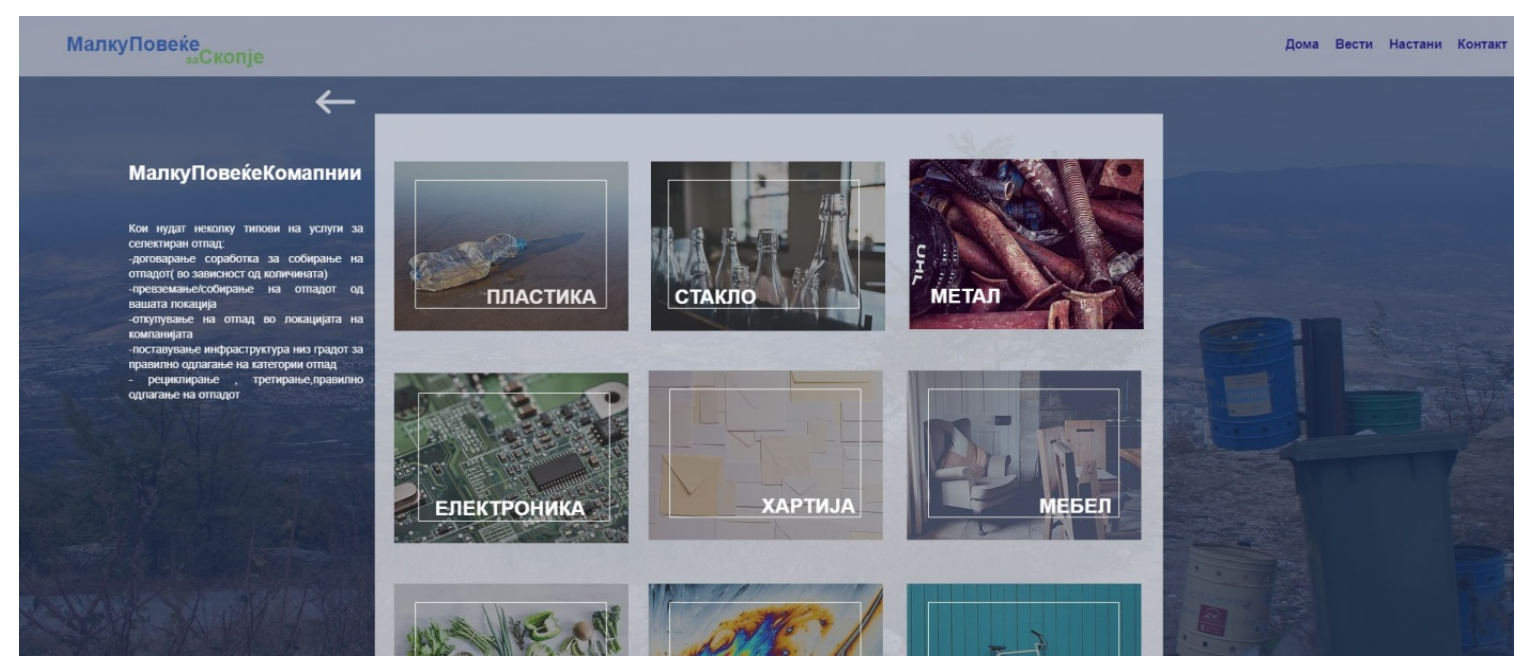

Сл. 46. Конечен изглед на страната МалкуПовеќеКомпании со информации средени по категории

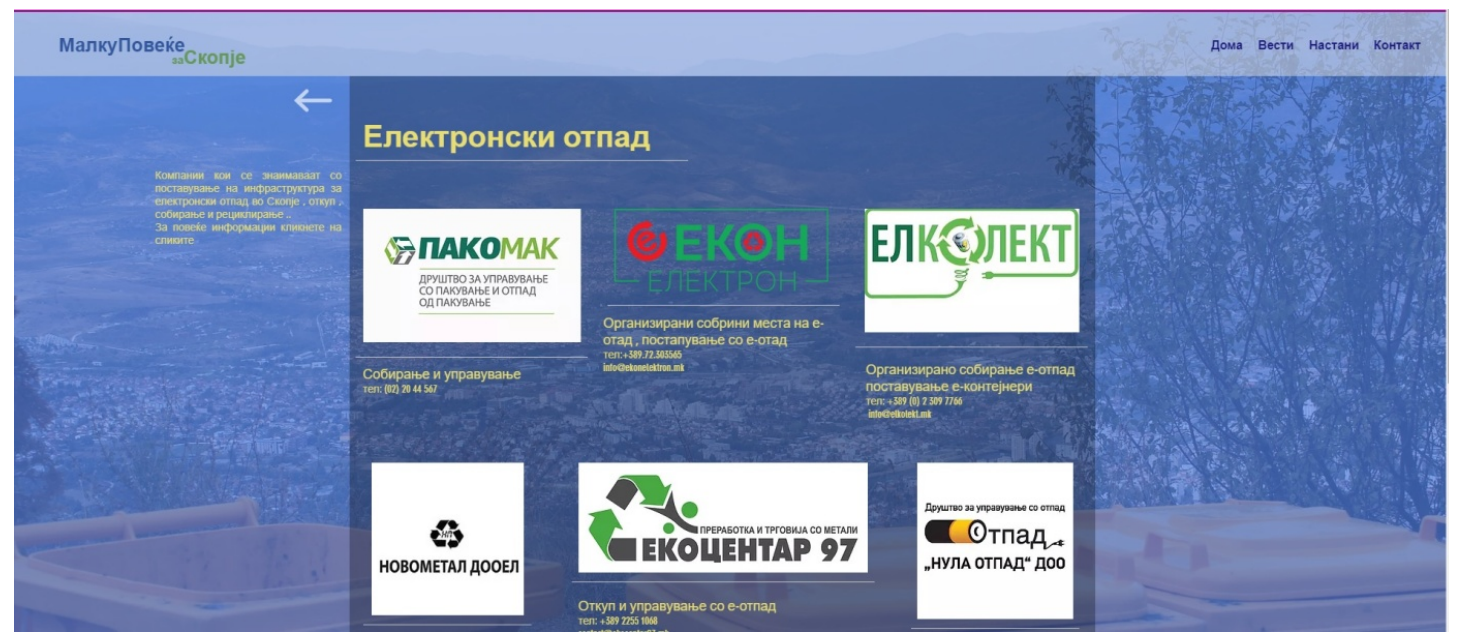

Сл. 47. Конечен изглед на страната со информации за компании кои собираат електронски отпад 


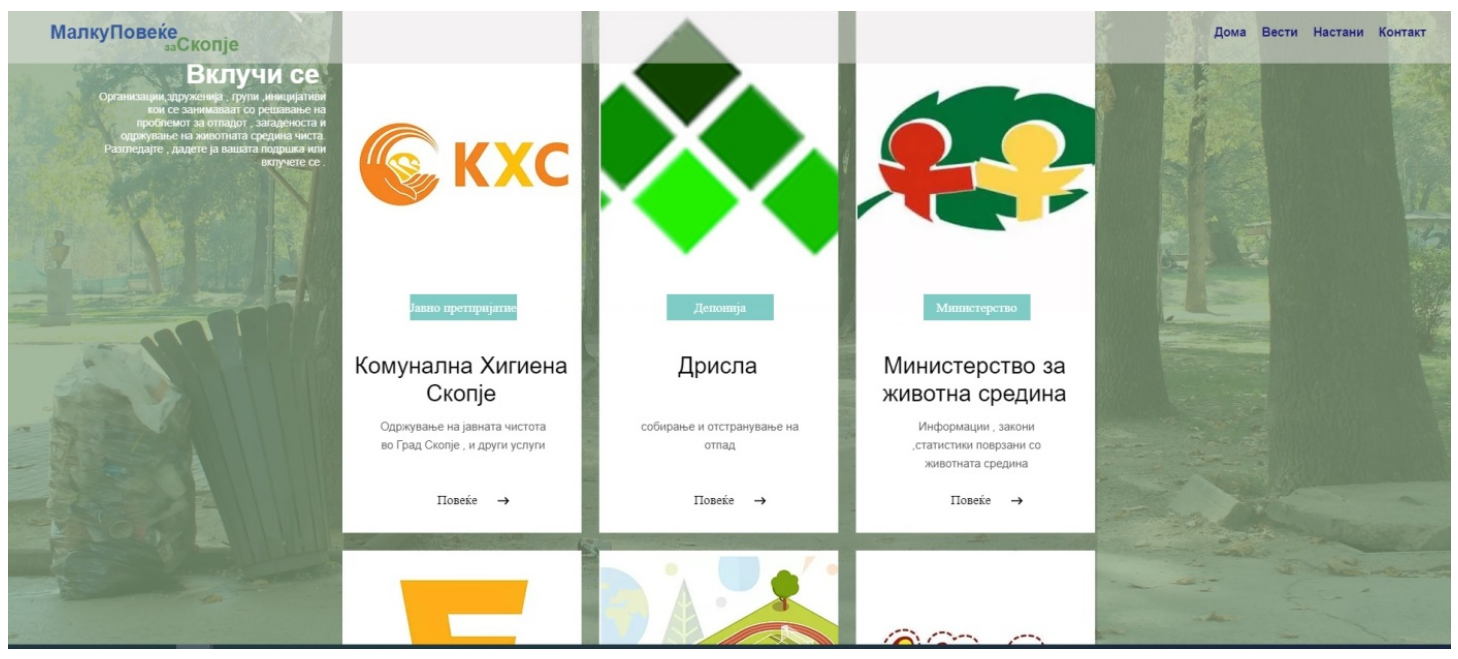

Сл. 48. Конечен изглед на страната Вклучи се

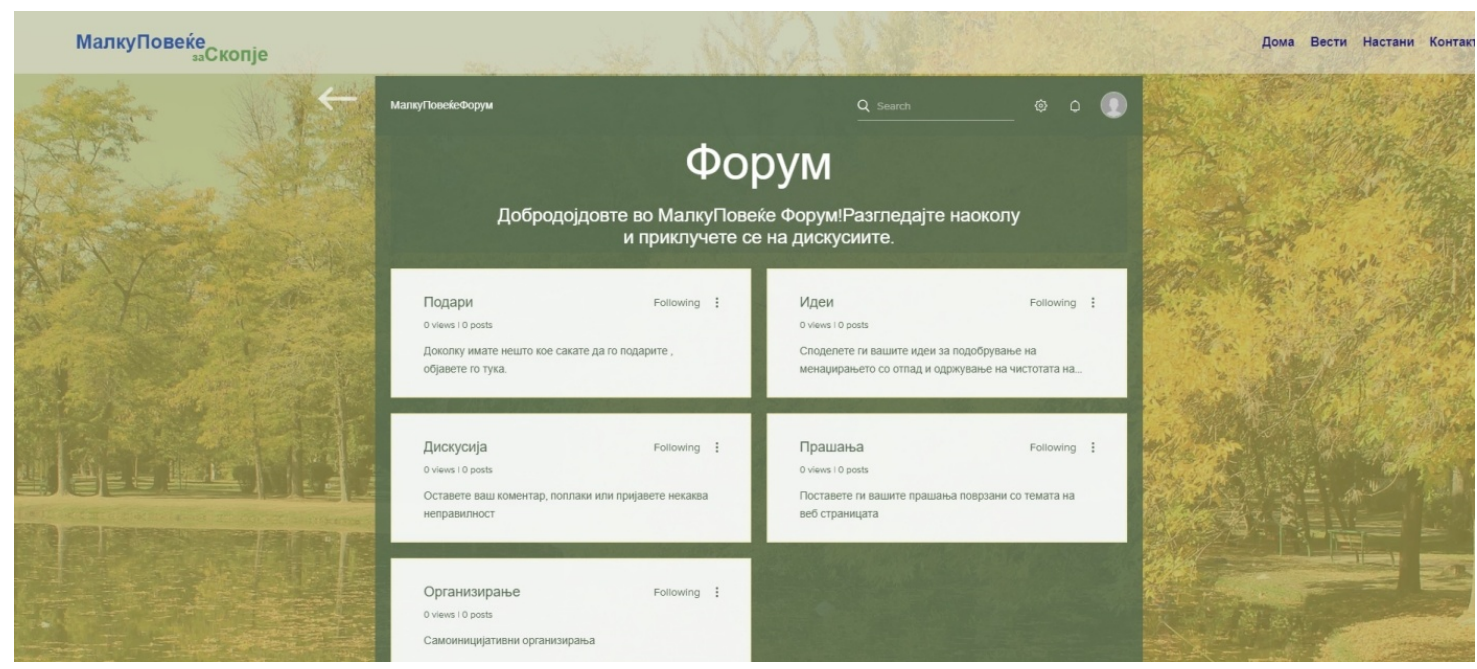

Сл. 49. Конечен изглед на страната Форум 


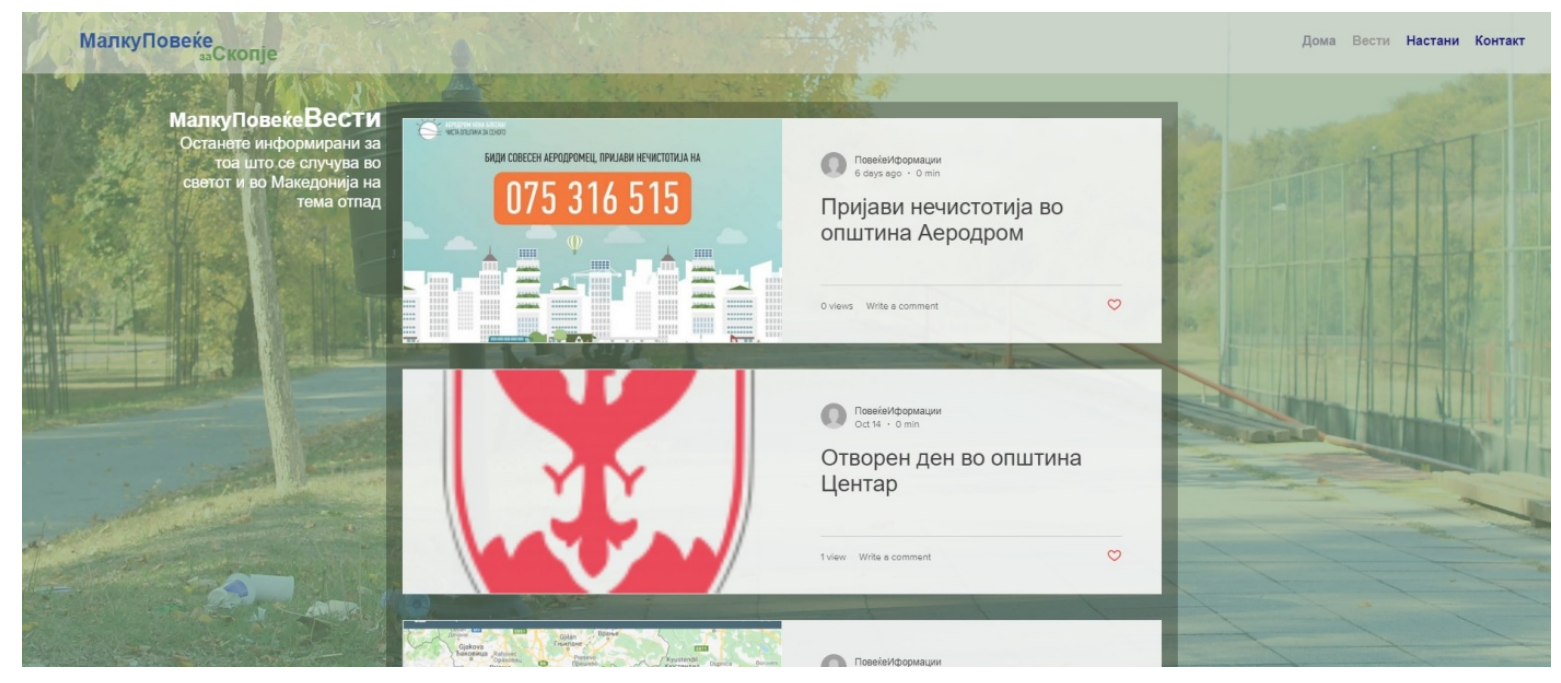

Сл. 50. Конечен изглед на страната МалкуПовеќеВести

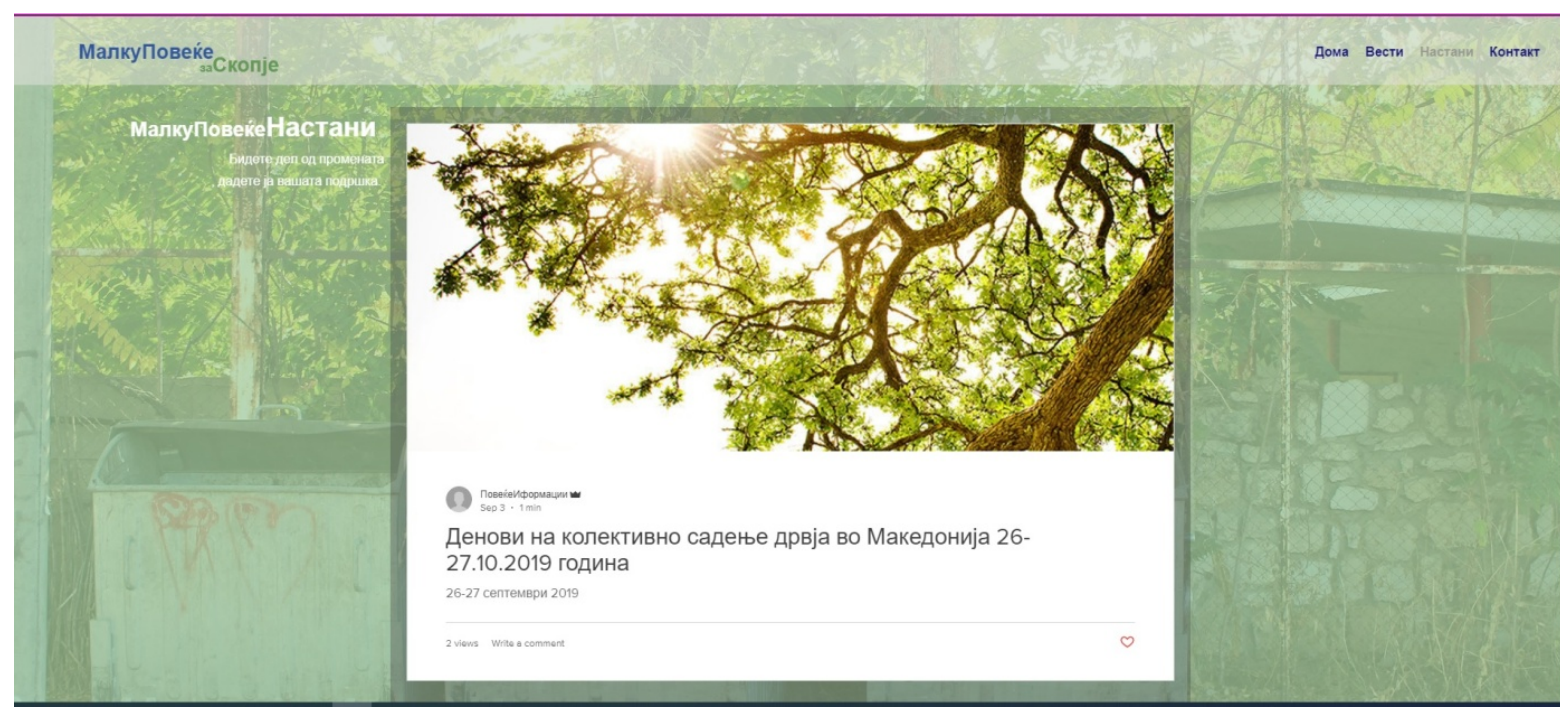

Сл. 51. Конечен изглед на страната МалкуПовеќеНастани 


\section{5. Заклучок}

Пред само 100-тина години, проблемот со отпадот бил речиси непостоечки. На пример, во Македонија пред 40-тина години пластиката била реткост. Од друга страна, количината на отпад која ја произведува град Скопје денес е речиси дуплирана од бројката пред околу 15 години. Развојот во индустријата, технологијата и модерниот свет, колку и да е за восхитување, со себе има повлечено и многу негативни последици. Навистина е загрижувачка бројката на предизвикани штети во екосистемот за многу краток временски период, што не доведува до заклучок дека можеби модерниот човек треба да учи од неговите предци, не подалеку од времето на младоста на родителите, во поглед на потрошувачкото консумерство и креирањето отпад.

Навикнати сме да слушаме како со неодговорни постапки и штетиме на планетата. Во некои случаи тоа не прави да се чувствуваме дека му штетиме на нешто друго, освен на самите себе. Факт е дека планетата постоела без човекот и не зависи од него. Планетата Земја има претрпено разни катастрофи, што посочува на тоа дека со тек на време би нашла начин да се справи со сите штети кои ги направил човекот. Сепак, кога го загадуваме воздухот, водата и почвата, го загадуваме нашиот извор на живот со нашето несовесно однесување и на крај си штетиме сами на себе, а не на некого или нешто друго.

Поради развиената фаза во која во моментот се наоѓа кризата со отпадот во светски рамки, креативните дизајнерски решенија се единствен излез се додека не се воспостави драстична промена во производството и вклучување во циркуларната економија. Сите идејни решенија разработени во овој труд имаат за цел да придонесат кон долгорочен позитивен импакт во општеството и истите наложуваат потреба за посветеност и сериозност од институциите за нивно имплементирање. Нивната реализација бара добро организирање, економски ресурси, просторно планирање, посветеност и квалитетна соработка, аспекти кои се невозможни за обезбедување од страна на еден студент. Од извршеното истражување извлечен е заклучок дека институциите и компаниите располагаат со ограничени капацитети, делумно поради политички причини, а делумно поради економски. Соработката со нив претставува многу долг и сложен процес со несигурен резултат. Токму поради тоа, речиси е невозможно индивидуално да се наложи промена во системот и во однесувањето на надлежните засегнати страни. Имајќ го тоа предвид, фокусот треба да се сврти кон оние кои го произведуваат отпадот - граѓаните.

Главната цел на овој магистерски труд е преку техниките на креативно размислување да се истражи општествениот проблем создаден од неправилно менаџирање со отпадот во урбаните средини. Потоа, следејќи ги дизајнерските чекори, да се анализира ситуацијата, дефинираат проблемите, генерираат идеи и детално да се разработат идејните решенија, од каде произлезе финалниот продукт на магистерската теза - информативна и едукативна веб платформа за справување со отпадот, наменета за граѓаните на Скопје.

Креираната веб-платформа е прва од овој тип во Македонија и ги таргетира токму оние, кои со нивното однесување придонесуваат најмногу во загадувањето на околината во урбаните 
средини. Од истражувањето направено за трудот, систематизирани се и добро организирани сите најважни информации кои се однесуваат на градот Скопје, и кои беа барани од страна на испитаниците. Се очекува веб-платформата да има долгорочен ефект и да го задржи својот примарно едукативен карактер, информирајќ ги жителите за правилно одлагање на отпадот, новостите на полето на менаџирање со отпадот, промените, иновациите и настаните чиј фокус е животната средина и урбаниот простор. Со оглед на тоа што како главно оправдување за некоректно постапување со отпадот беше посочен фактот за недоволниот пристап до овој тип на информации, се очекува онлајн-страницата да има големо влијание врз подигањето на свеста на жителите во градот за оваа проблематика.

Форумот, кој е многу важен дел од платформата, овозможува интеракција помеѓу корисниците, охрабрува разни дискусии, организирање и преземање иницијативи и функционира како огласна табла за размена на веќе користени предмети. Форумот е важен чекор кон процесот на креирање на јака заедница со исти интереси, која како група, понатаму би можела да воспостави соработка со институциите. Оттука би произлегле можности за реализација на останатите идејни решенија понудени во магистерскиот труд и би се извршило влијание за поголеми промени во системот.

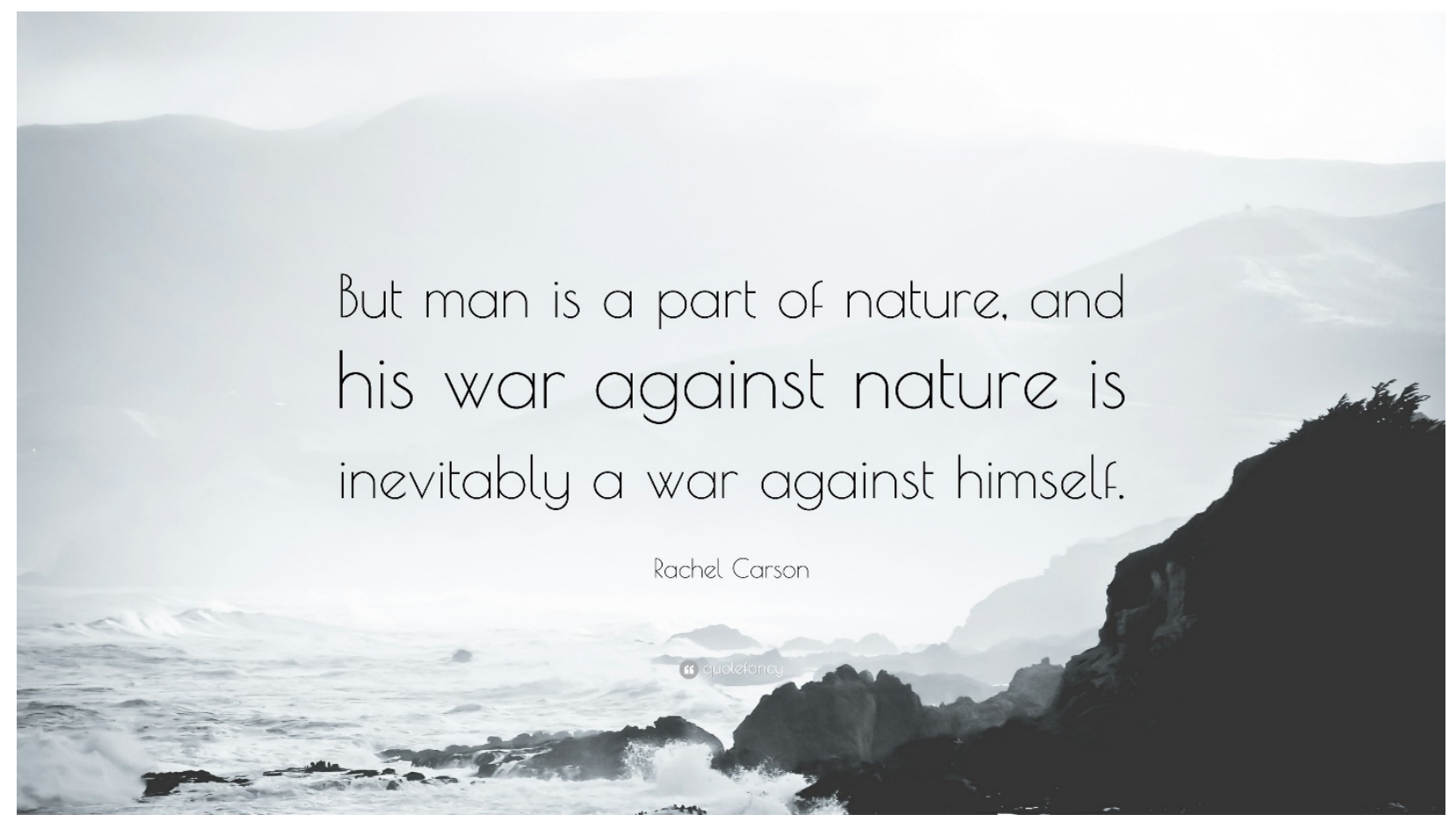


Користена литература

[1] Robert A Curedale "Design thinking process \& methods 4th edition" December 2017.Published by Design Community College Inc. Los Angeles

[2] Thomas Lockwood "Design Thinking: Integrating Innovation, Customer Experience, and Brand Value"February 2010 published by Allworth Press Design Management Institute

[3] Gretchen Anderson"Designing for Social Impact." June 2015 Publisher: O'Reilly Media, Inc.

[4] Alex Nicholls (Herausgeber), Julie Simon (Herausgeber), Madeleine Gabriel (Herausgeber), Christopher Whelan (Herausgeber) "New Frontiers in Social Innovation Research" September 2015 First published by Palgrave Macmillan

[5] Ezio Mazini "Design, When Everybody Designs: An Introduction to Design for Social Innovation" February 2015 The MIT Press Cambridge ,Massachusetts London ,England pp 55-74.

[6]Cristina M. Pulido, Gisela Redondo-Sama ,Teresa Sorde'-Marti' ,Ramon Flecha"Social impact in social media: A new method to evaluate the social impact of research"August 2018 Pulido et al. Plos one

[7] Tim Brown "Change by design" Sep 29, 2009/Publisher HarperColins

[8] Nilsson, C. and Á. L. Aradóttir "Ecological and social aspects of ecological restoration: new challenges and opportunities for northern regions" 2013 Published here under license by the Resilience Alliance.

[9] Tzoulas K, Korpela K, Venn S, Ylipelkonen V, Kazmieczak A, Niemelä J, James P. "Promoting ecosystem and human health in urban areas using green infrastructure. Landscape and Urban Planning". 2007;81:167-178. doi: 10.1016/j.landurbplan.2007.02.001 ,pp 09-20

[10] Angelstam P, Andersson K, Annerstedt M, Axelsson R, Elbakidze M, Garrido P, Grahn P, Jönsson KI, $\underline{\text { Pedersen } S}$, Schlyter $\mathrm{P}$, Skärbäck E, Smith M, Stjernquist I. "Solving Problems in Social-Ecological Systems: Definition, Practice and Barriers of Transdisciplinary Research" . 2013 Mar; 42(2): 254-265.

[11] Lisa V. Bardwell "Problem-Framing: A perspective on environmental problem-solving" September 1991, Volume 15, Issue 5, pp 603-612

[12] Roland Geyer · Jenna Jambeck · Kara Lavender Law "Production, use, and fate of all plastics ever made" July 2017. 1700782 SM Research Article. American Association for the Advancement od Science. Pp 01-05

[13] CHOI, HYE JUNG "The Environmental Effectiveness of Solid Waste Management" A Case Study of Oslo, Norway ,Master thesis in Culture, Environment and Sustainability Centre for Development and Environment UNIVERSITY OF OSLO Spring, 2016. pp 37-44 
[14] Armstrong, L., Bailey, J., Julier, G. and Kimbell, L., 2014. Social design futures: HEI research and the AHRC. University of Brighton, 2(1-4), 17-27.

[15] Woodcraft, S., Hackett, T. and Caistor-Arendar, L. " Design for social sustainability: A framework for creating thriving new communities." Published by Social Life 2012, pp 14-20.

[16] Cooper-Hewitt "Design and Social Impact: A cross-sectional agenda for design education, research, and practice" 2013.The Smithsonian's Cooper-Hewitt, National Design Museum, in conjunction with the National Endowment for the Arts and The Lemelson Foundation, 3(1-2),32-34.

[17] Bergvall-Kåreborn, B. and Ståhlbrost, A.," Participatory design: one step back or two steps forward?" 2008, October.. In Proceedings of the tenth anniversary conference on participatory design 2008 (pp. 102-111). Indiana University, 3(1), 2-3.

[18] Mulgan, G., Tucker, S., Ali, R. and Sanders, B.,. "Social innovation: what it is, why it matters and how it can be accelerated" 2007. Skoll Centre for Social Entrepreneurship, 3(1),8-9.

[19] Славе Ристоманов ,Развој на веб платформа за промовирање на методологијата дизајн со општествено влијание „2019 Машински Факултет Скопје стр 26-65

[20] Bob Gill "Graphic design as second language" 2003 The Images Publishing Group Pty Ltd p. 7

[21] Jeanne Liedtka "Design Thinking for the Greater Good: Innovation in the Social Sector" 15 August 2017 Columbia University Press, New York Chichester , West Sussex

[22] Salah M. El-Haggar "Sustainable Industrial Design and Waste Management Cradle-to-cradle for Sustainable Development" 2007 Elsevier Academic Press

[23] Jones, John Christopher, Design Methods: seeds of human futures, John Wiley \& Sons Ltd., London, 1970; 2nd edition, John Wiley \& Sons Ltd., 1992

[24] Ed Gardner "It's time to experiment with social impact " 2019 Design Council

[25]Rhoda Sell " Design Thinking : A beginner's guide to the history, terminologies and methodologies" June 2018 , Prototypr.io

[26] “Design Thinking: Understanding How Designers Think and Work and Design Expertise “ Translations no.5 - (c) 2015 Arts Education Collaborative

[27] Rikke Dam and Teo Siang "5 Stages in the design thinking process " - Interaction Design Fundation (https://www.interaction-design.org/)

[28] Annie Kelly "Money wasted in water projects in Africa" -26 march 2009 The Guardian (https://www.theguardian.com/society/katineblog/2009/mar/26/water-projects-wasted-money)

[29] Puja Mondal "Social Problems : Elements, sources and types of social problems" -Article Library (http://www.yourarticlelibrary.com/) 
[30] Megan Ray Nicholis "The top 10 environmental issues should make you worry" -22 march 2019 ,Schooled by science (https://schooledbyscience.com/environmental-issues/)

[31] Audrey Holmes “How Many Times Can That Be Recycled?" June 15, 2017 Earth911 Article (https://earth911.com/)

[32] Владимир Калински „Како Република Депонија ќе се справи со отпадот?, 26 Февруари , 2019 Радио слободна Европа

[33] Бранко Прља "Рециклирање во земјата на чудата - што може да се рециклира во Македонија, а што не, како и каде? "24 Јуни 2019 Рес публика

[34] Владимир Калински "Неформални собирачи собираат над 80 насто од отпадот за рециклирање" Јули 17, 2018 Радио Слободна Европа

[35] David Biddle "Recycling for Profit: The New Green Business Frontier" November December 1993 issue Harvard Bussines review

[36] Ron Gonen "Yes, recycling is still good business - if this happens" July 30, 2015 GreenBIZ (https://www.greenbiz.com/)

[37] Ryan May -,,Creativity and Innovation in the workplace" - Article 657 Bussines Dictionary (http://www.businessdictionary.com)

[38] Elliot Stein "The 96-year-old-painter who saved a village " 29 November 2018

BBC(http://www.bbc.com/travel/gallery/20181128-the-96-year-old-painter-who-saved-a-village)

[39] Stanford design institute -https://dschool.stanford.edu/

[40] Core77 Design Awards 2018 https://www.core77.com/Core77-Design-Awards

[41] ' 7 Design Projects Making Serious Social Impact'Ivy -bussines management platform for designers https://www.ivy.co/

[42] https://fabscrap.org/

[43] https://en.wikipedia.org/wiki/Social issue

[44] First for Sustainability -https://firstforsustainability.org/

[45] https://nowthisnews.com/videos/politics/humans-reportedly-have-made-91-billion-tons-of-plasticsince-1950

[46] Environmental Protection Agency https://www.epa.gov/

[47] https://www.oecd.org/

[48] https://www.moepp.gov.mk/

[49] https://skopje.gov.mk/

[50] http://www.stat.gov.mk/ 
[51] www.gjubre.mk

[52] https://iportal.mk/makedonija/vo-makedonija-ima-stotici-divi-deponii-zagadeni-industriskilokaliteti/

[53] www.reagiraj.mk

[54] www.samoprasaj.mk

[55] https://www.plasticstoday.com/

[56]" https://www.weforum.org/agenda/2017/12/germany-recycles-more-than-any-other-country/

[57] The swedush recycling revolution -Dominic Hinde 19 July 2019 www.sweden.se

[58]Precious Plastic Movement www.preciousplastic.com

[59] Keep America Beautiful www.kab.org/

[60] https://www.vice.com/en au/article/xwn5k7/school-india-lets-kids-pay-education-tuition-recyclingplastic-waste-garbage-trash

[61] https://www.fastcompany.com/90256788/in-this-indonesian-city-recycling-gets-people-a-free-busticket

[62] www.fakulteti.mk

[63] Madiba and Nature www.madibanature.com

[64] https://www.dw.com/en/public-benches-printed-from-plastic-trash/av-48769348

[65]" www.inovativnost.mk

[66] www.forbes.com

[67] https://clp.mk/nitu-edna-komunalna-sluzhba-ne-mozhe-da-ischisti-milionski-grad-ako-site-frlaatkaj-ke-stignat/

[68]”Македонија преработува само 10\% од отпадот кој го создава “ - април 2016, апитал https://kapital.mk/kategorija/makedonija/

[69] https://okno.mk/node/78836

[70] https://www.radiomof.mk/pakomak-krajno-vreme-e-neformalnite-sobirachi-da-se-integriraat-voorganiziran-sistem-za-sobiranje-otpad/

[71] www.elkolekt.mk

[72] www.drisla.mk 